\title{
Forecast of Transportation Energy Demand Through the Year 2010
}

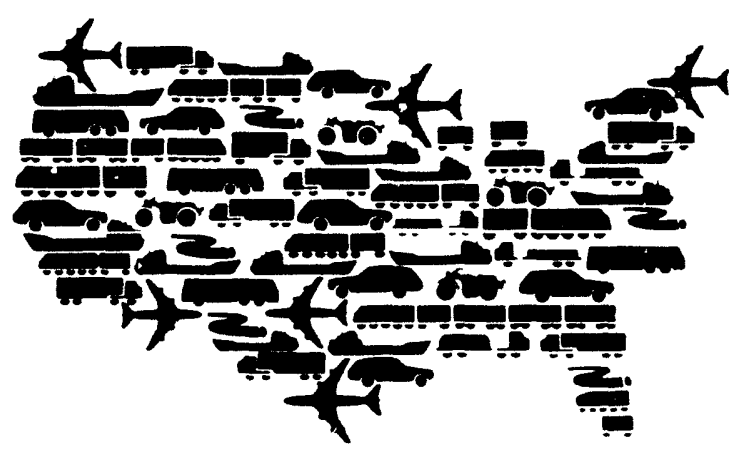

Center for Transportation Research Argonne National Laboratory

Operated by The University of Chicayo, under Contract W-31-109-Eng-38, ior the United States Department of Energy 


\section{Argonne National Laboratory}

Argonne National Laboratory, with lacilities in the states of Illino is and Idaho, is owned by the United States government, and operated by the University of Chicago under the provisions of a contract with the Department of Energy.

This technical report is a product of Argonne's Energy Systems Division. For information on the division's scientific and engineering activities, contact:

Director, Energy Systems Division

Argonne National Laboratory

Argonne, Illinois 60439-4815

Telephone (708) 972-3724

\section{Disclaimer}

This report was prepared as an account of work sponsored by an agency of the United States Government. Neither the United States Government nor any agency thereof, nor any of their employees, makes any warranty, express or implied, or assumes any legal liability or responsibility for the accuracy, completeness, or usefulness of any information, apparatus, product, or process disclosed, or represents that its use would not infringe privately owned rights. Reference herein to any specific cornmercial product, process, or service by trade name, trademark, manufacturer, or otherwise, does not necessarily constitute or imply its endorsement, recommendation, or favoring by the United States Government or any agency thereof. The views and opinions of authors expressed herein do not necessarily state or reflect those of the United States Government or any agency thereot.

Reproduced from the best available copy. Available from the National Technical Information Service (NTIS), U.S. Department of Commerce, 5285 Port Royal Road, Springfield, Virginia 22161.

NTIS price codes:

Printed copy A06

Microfiche 
ANL/ESD- -9

DE92 000222

ANL/ESD-9

\section{Forecast of Transportation Energy Demand Through the Year 2010}

by M.M. Mintz and A.D. Vyas

Center for Transportation Research, Energy Systems Division,

Argonne National Laboratory, 9700 South Cass Avenue, Argonne, Illinois 60439

November 1990 (revised April 1991)

Work sponsored by United States Department of Energy,

Assistant Secretary for Conservation and Renewable Energy, Office of Transportation Technologies 


\section{CONTENTS}

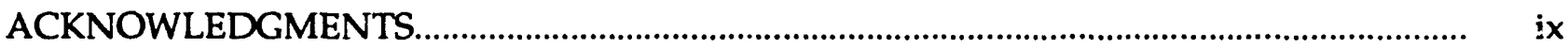

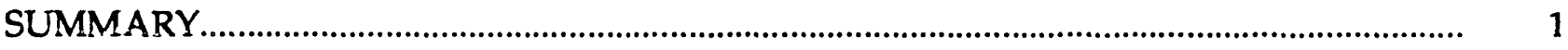

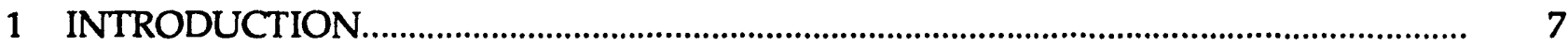

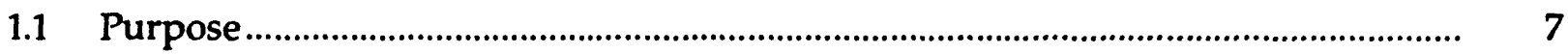

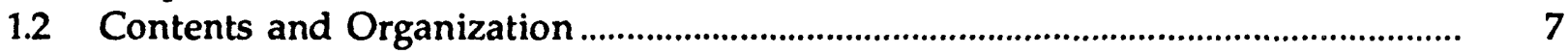

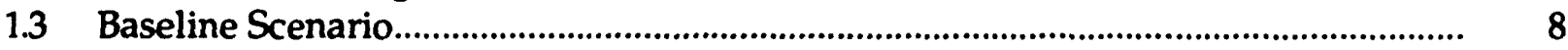

1.3.1 Economic and Demographic Assumptions .................................................... 8

1.3.2 Transportation Technology Assumptions .................................................... 9

1.3.3 Transportation Policy Assumptions..................................................... 12

2 PROJECTION METHODOLOGY AND RESULTS: PASSENGER MODES................... 14

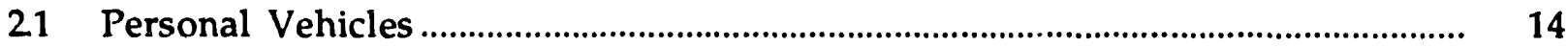

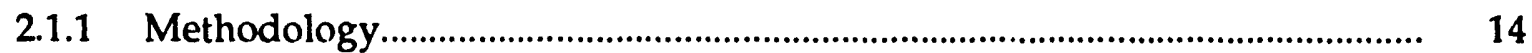

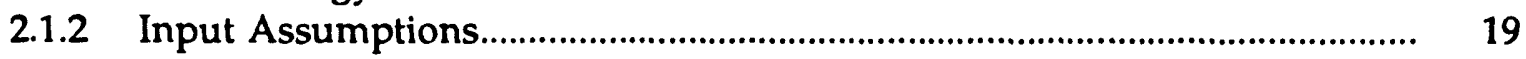

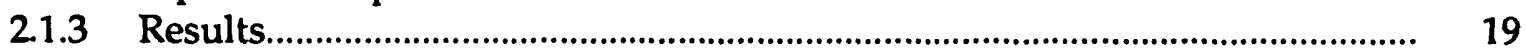

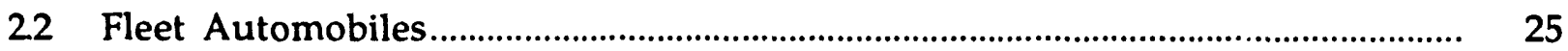

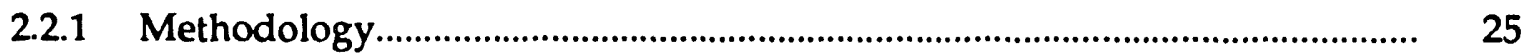

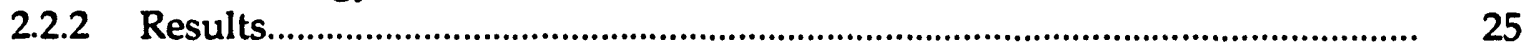

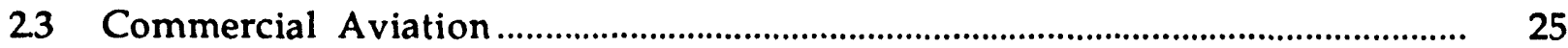

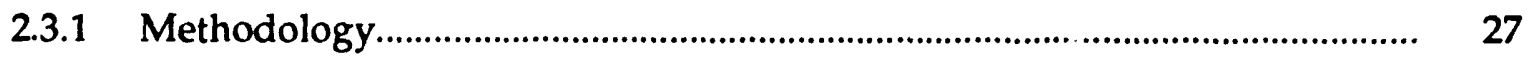

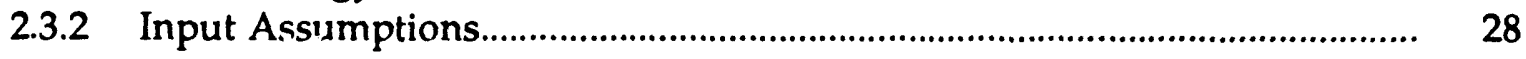

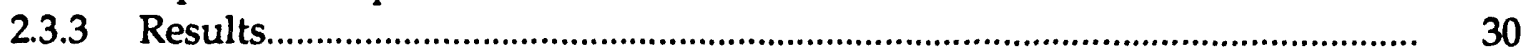

2.3.4 Comparison with Other Current Forecasts........................................... 31

3 PROJECTION METHODOLOGY AND RESULTS: FREIGHT MODES ........................... 34

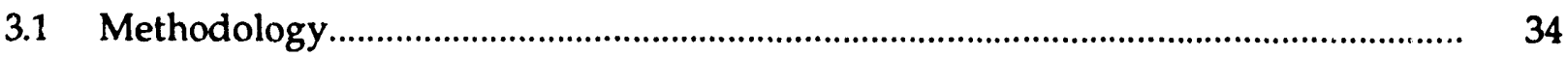

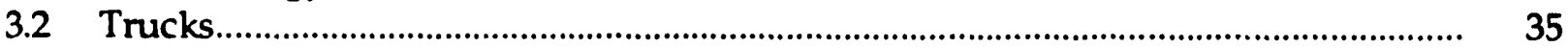

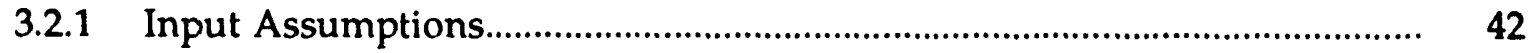

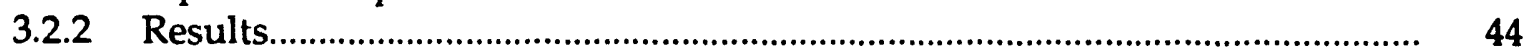

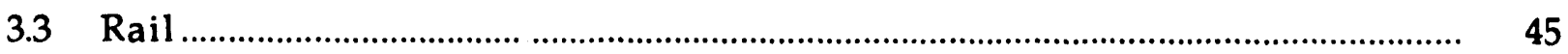

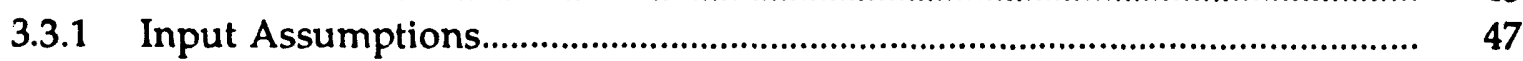

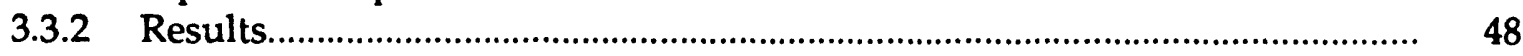

3.3.3 Comparison with Other Forecasts ......................................................... 48

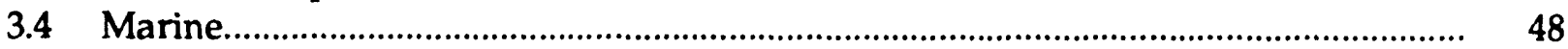

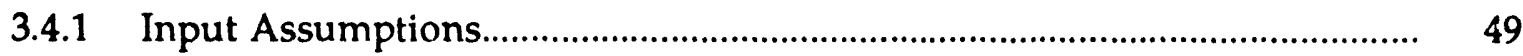

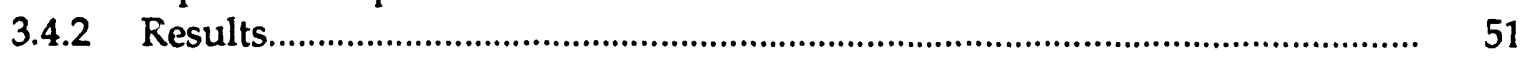

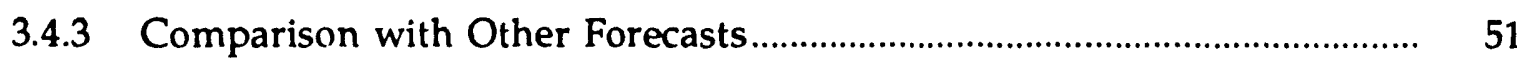




\section{CONTENTS (Cont'd)}

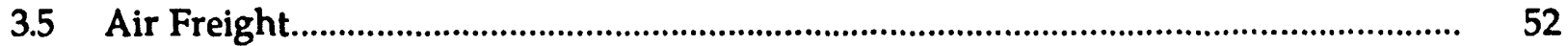

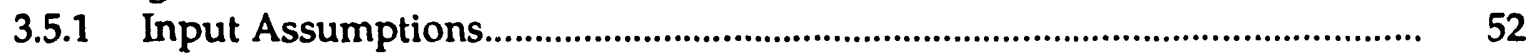

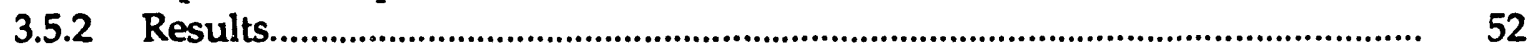

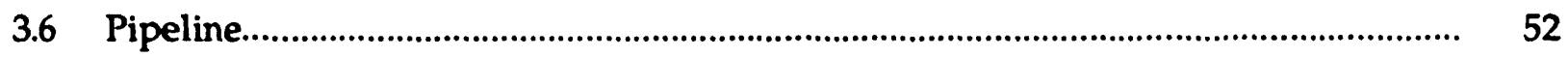

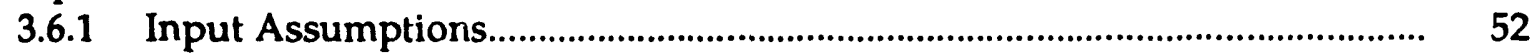

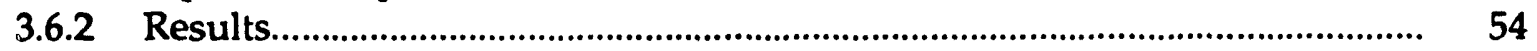

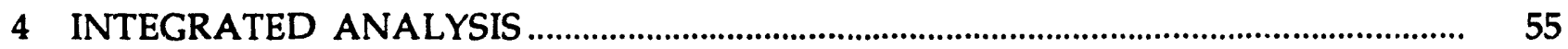

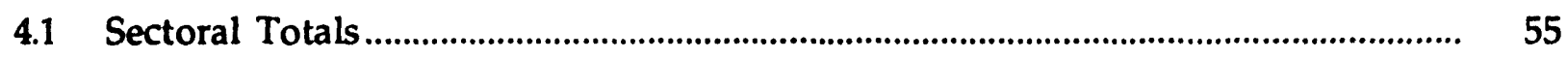

4.1.1 Energy Consumption ............................................................................... 55

4.1.2 Fuel Composition........................................................................................ 55

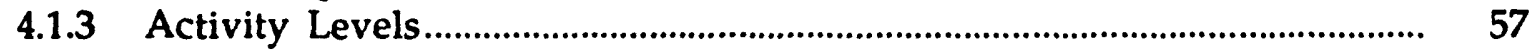

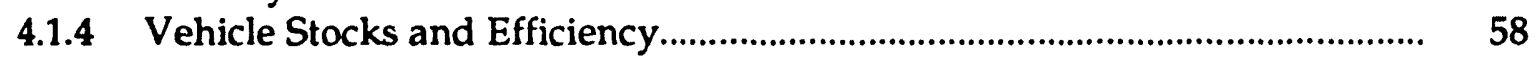

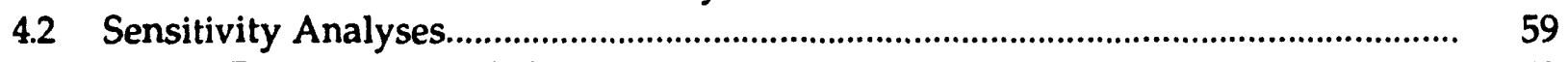

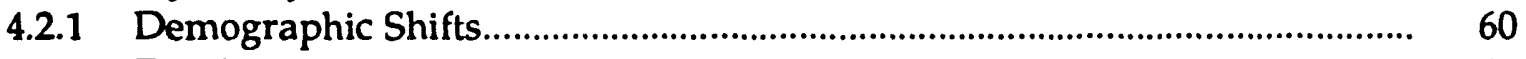

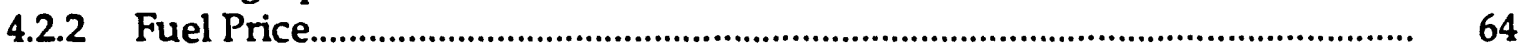

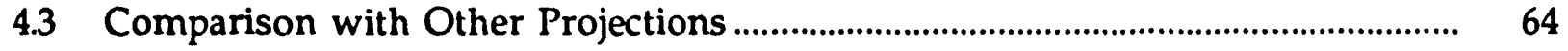

4.3.1 Automobiles and Other Personal Vehicles ................................................... 66

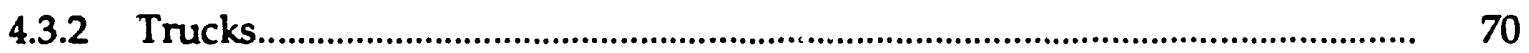

4.4 Comparison with Earlier ANL Projections ......................................................... 71

4.4.1 Transportation Energy.............................................................................. $\quad 74$

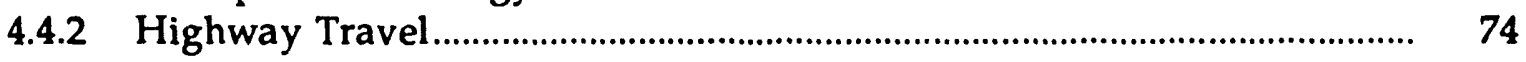

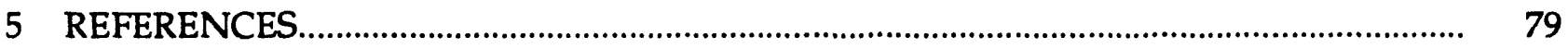

APPENDIX A: ESTIMATION OF BASE-YEAR FREIGHT MOVEMENTS....................... $\quad 85$

APPENLIX B: ESTIMATION OF 1985 PERSONAL TRAVEL ......................................... 95 


\section{TABLES}

S.1 Travel and Fuel Use by Personal Motor Vehicles, 1985-2010.................................. 2

S.2 Travel and Fuel Use by Nonpersonal Motor Vehicles, 1985-2010 .......................... 3

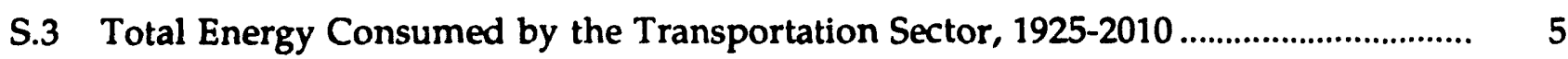

S.4 Highway Vehicles, Fuel Economy, and Miles Traveled, 1985-2010.......................... 6

1.1 Economic and Demographic Assumptions, 1985-2020 .............................................. 10

1.2 Distributions of Households by Demographic Attribute, 1985-2020......................... 11

21 Characteristics of the Personal Vehicle Fleet, 1985-2010......................................... 20

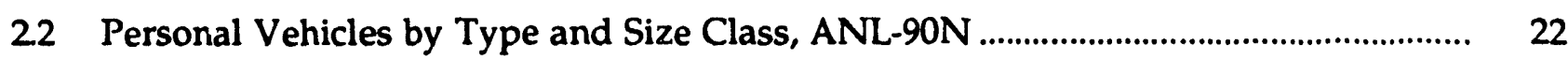

2.3 Vehicle-Miles Traveled by Type and Size of Personal Vehicle, ANL-90N............... 23

24 Fuel Use by Type and Size of Personal Vehicle, ANL-90N .................................... 24

25 Fuel Economy of Personal Vehicles, ANL-90N........................................................ 24

26 Characteristics of Nonhousehold Autos by Area of Operation, 1983........................ 26

27 Projected Characteristics of Fleet Automobiles, ANL-90N...................................... 27

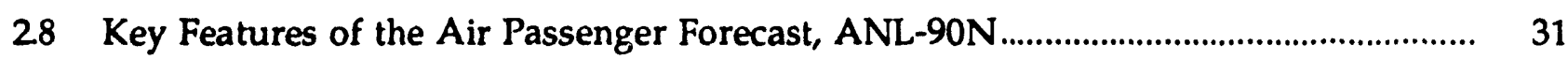

29 Forecasts of Domestic Revenue Passenger-Miles and Jet Fuel Use, 1985-2010.......... 32

3.1 Characteristics of the Heavy-Duty Truck Inventory, 1982 ......................................... 37

3.2 Commercial Trucks by Type of Product Carried, 1982 ............................................. 38

3.3 Commercial Trucks by Size Class for Principal Product Categories, 1982................. 40

3.4 Commercial Trucks, Vehicle- and Ton-Miles Traveled by Major Use Category, 1982............................................................................................................. 41

3.5 Truck Technology and Operating Improvements............................................. 44

3.6 Diesel Shares by Truck Size Class, 1985-2010....................................................... 


\section{TABLES (Cont'd)}

3.7 Commercial Truck VMT and Energy Use by Size Class, 1970-2010......................... 46

3.8 Rail Ton-Miles, Energy Use, and Energy Intensity, 1970-2010 ................................ 47

3.9 Forecasts of Rail Freight Ton-Miles, Fuel Consumption, and Fuel Efficiency, 1985-2010.

3.10 Domestic Waterborne Freight Ton-Miles, Energy Use, and Energy Intensity, 1970-2010

3.11 Projections of Energy Consumed in Waterborne Commerce for Domestic and International Shipping, 1985-2010.

3.12 Domestic Air Freight Ton-Miles, Energy Use, and Energy Intensity, 1970-2010 ....... 53

3.13 Pipeline Ton-Miles, Energy Use, and Energy Intensity, 1970-2010........................... 54

4.1 Transportation Energy Use by Mode, 1970-2010................................................... 56

4.2 Transportation Energy Consumption by Type of Fuel, 1970-2010........................... 59

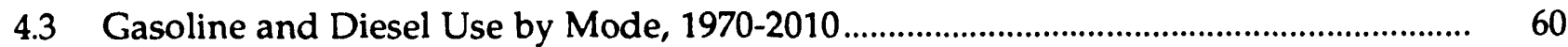

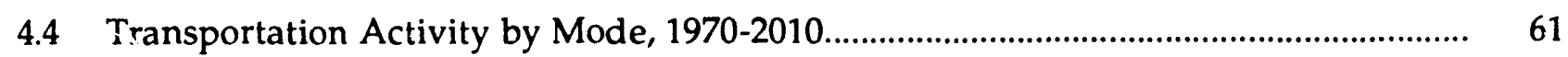

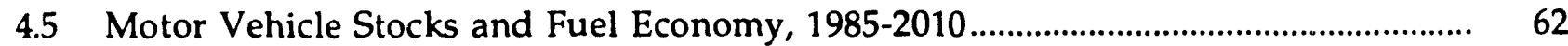

4.6 Sensitivity to Travel Assumptions: Comparison of Personal Travel and Fuel Use for Alternative Demographic Inputs.

4.7 Sensitivity to Alternative Fuel Prices: Comparison of ANL-90N and ORNL/NES Results.

4.8 Forecast Comparisons: Personal Vehicle Stocks, Vehicle-Miles, Fuel Consumption, and Fuel Economy, 1985-2010.

4.9 Forecast Comparisons: Truck Stocks, Vehicle-Miles, Fuel Consumption, and Fuel Economy, 1985-2010.

A.1 Truck Ton-Miles, Vehicle-Miles, Average Loads, and Size Shares by Sector. 86

A.2 Production Indices for 1982 and 1985, Estimated Truck VMT, and Mode Shares by Sector. 
TABLES (Cont'd)

A.3 Rail, Water, Pipeline, and Air Freight Ton-Miles by Sector..................................... 90

A.4 Freight Sector Energy Intensities for Nonhighway Modes....................................... 92

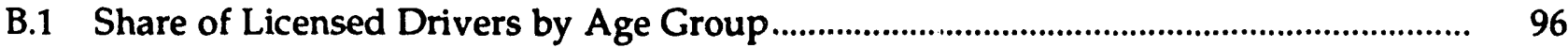

B.2 Development of the Base-Year Households Distributions........................................ 97 


\section{FIGURES}

21 Iterative Proportional Fitting over Time, Two-Margin Case..................................... 16

4.1 Transportation Energy Consumption by Mode, 1960-2010 ........................................ 57

4.2 Personal Versus Commercial Vehicle Energy Use, 1960-2010................................... 58

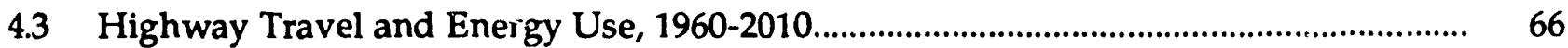

4.4 Automotive Fuel Economy Versus Gasoline Price, 1960-2010................................... 70

4.5 Per-Capita Automotive VMT and Per-Mile Travel Cost, 1960-2010........................ 71

4.6 Projection Comparisons: Transportation Energy Use, 1960-2010.............................. 75

4.7 Projection Comparisons: Highway Travel and Fuel Use, 1960-2010....................... 76

4.8 Projection Comparisons: Automotive Travel and Fuel Cost, 1960-2010................. 77

4.9 Projection Comparisons: Automotive Fuel Economy and Gasoline Price,

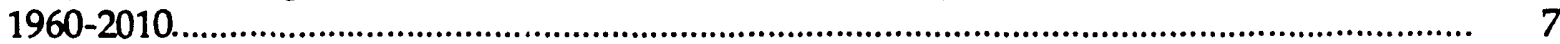




\section{ACKNOWLEDGMENTS}

The authors gratefully acknowledge several individuals without whose help this project could not have been completed. Special thanks go to Philip D. Patterson of the U.S. Department of Energy, Office of Transportation Technologies, who sponsored the work. His patience and general assistance during the model-development process and careful review of results were invaluable. Additional thanks go to David Hudson, Energy and Environmental Analysis Division, Solar Energy Research Institute; David Greene, Transportation Energy Group, Oak Ridge National Laboratory; and K.G. Duleep, Energy and Environmental Analysis, Inc. Their thorough and timely review of this document and many comments and helpful suggestions are sincerely appreciated. Lastly, the authors wish to thank members of the editorial and word processing staffs for their diligence and patience in preparing this manuscript for publication. 


\section{FORECAST OF TRANSPORTATION ENERGY \\ DEMANU THROUGH THE YEAR 2010}

by

M.M. Mintz and A.D. Vyas

\section{SUMMARY}

This is a summary report documenting the process used to forecast transportation activity and energy demand through the year 2010. It was developed by the Center for Transportation Research at Argonne National Laboratory under contract to the Office of Transportation Technologies under the Assistant Secretary for Conservation and Renewable Energy of the U.S. Department of Energy. The latest in a series of reports documenting the evolution of the forecasting system, this report presents the current forecast, termed ANL- $90 \mathrm{~N}$, both as a baseline against which to analyze trends and evaluate existing and proposed energy conservation programs and as an islustration of how the modelin process works. The document is organized into two complementary sections -one discussing passenger transportation modes, the other discussing freight transportation modes -- followed by descriptions of further analytical results, comparisons with other forecasts, and documentation of calibration data sets.

Tables S.1-S.4 summiarize this latest baseline forecast. Tables S.1 and S.2 present ANL-90N forecasts of travel and fuel use by personal and nonpersonal vehicles, respectively. Table S.3 summarizes the ANL-90N forecast of energy consumption by mode and fuel type, while Table S.4 summarizes the forecast of highway vehicle stocks, fuel economy, and miles traveled. 
TABLE S.1 Travel and Fuel Use by Personal Motor Vehicles, ${ }^{2}$ 1985-2010

\begin{tabular}{|c|c|c|c|c|c|c|}
\hline \multirow[b]{2}{*}{ Item } & \multicolumn{5}{|c|}{ Value, by Year } & \multirow{2}{*}{$\begin{array}{c}\text { Change, } \\
1985-2010 \\
(\% / y r)\end{array}$} \\
\hline & 1985 & 1990 & 1995 & 2000 & 2010 & \\
\hline \multicolumn{7}{|c|}{ Vehicle-Miles Traveled $\left(10^{9}\right)$} \\
\hline Autos & 1057.8 & 1235.8 & 1307.7 & 1386.6 & 1570.3 & 1.59 \\
\hline Trucks & 209.3 & 266.0 & 312.9 & 345.4 & 384.9 & 2.47 \\
\hline Total & 1267.0 & 1501.8 & 1620.5 & 1732.0 & 1955.1 & 1.75 \\
\hline \multicolumn{7}{|l|}{ Energy (10 15 Btu) } \\
\hline Autos & 7.396 & 7.825 & 8.045 & 8.265 & 8.085 & 0.36 \\
\hline Trucks & 1.921 & 2.223 & 2.544 & 2.743 & 2.718 & 1.40 \\
\hline Total & 9.317 & 10.047 & 10.589 & 11.009 & 10.803 & 0.59 \\
\hline \multicolumn{7}{|c|}{ Energy by Fuel Type ( $\left.10^{15} \mathrm{Btu}\right)$} \\
\hline Gasoline & 9.206 & 9.956 & 10.507 & 10.901 & 10.665 & 0.59 \\
\hline Diesel & 0.110 & 0.091 & 0.081 & 0.107 & 0.138 & 0.90 \\
\hline \multicolumn{7}{|l|}{ Fuel Economy (mpg) } \\
\hline Autos & 17.9 & 19.1 & 20.3 & 21.0 & 24.3 & 1.23 \\
\hline Trucks & 13.6 & 14.5 & 15.4 & 15.7 & 17.7 & 1.05 \\
\hline Total & 17.0 & 18.0 & 19.1 & 19.7 & 22.7 & 1.15 \\
\hline \multicolumn{7}{|l|}{ Vehicles $\left(10^{6}\right)$} \\
\hline Autos & 122.3 & 140.4 & 150.6 & 161.5 & 184.7 & 1.66 \\
\hline Trucks & 23.5 & 29.6 & 35.4 & 39.6 & 44.6 & 2.59 \\
\hline Total & 145.8 & 170.0 & 186.0 & 201.2 & 229.4 & 1.83 \\
\hline
\end{tabular}

aHousehold-based vehicles only. Fleets are excluded. 
TABLE S.2 Travel and Fuel Use by Nonpersonal Motor Vehicles, 1985-2010

\begin{tabular}{|c|c|c|c|c|c|c|}
\hline \multirow[b]{2}{*}{ Item } & \multicolumn{5}{|c|}{ Value, by Year } & \multirow{2}{*}{$\begin{array}{c}\text { Change, } \\
1985-2010 \\
(\% / y r)\end{array}$} \\
\hline & 1985 & 1990 & 1995 & 2000 & 2010 & \\
\hline \multicolumn{7}{|l|}{ Passenger Travel } \\
\hline \multicolumn{7}{|l|}{ Fleet Autos } \\
\hline Energy (105 Btu) & $\begin{array}{l}204.7 \\
1.286\end{array}$ & $\begin{array}{l}210.7 \\
1.242\end{array}$ & $\begin{array}{l}238.7 \\
1.320\end{array}$ & $\begin{array}{l}270.4 \\
1.448\end{array}$ & $\begin{array}{l}324.5 \\
1.501\end{array}$ & $\begin{array}{l}1.86 \\
0.62\end{array}$ \\
\hline \multicolumn{7}{|l|}{ Busesb } \\
\hline $\mathrm{VMT}^{2}\left(10^{9}\right)$ & 6.3 & 6.7 & 7.0 & 7.4 & 7.7 & 0.81 \\
\hline Energy (10 15 Btu) & 0.161 & 0.169 & 0.176 & 0.184 & 0.190 & 0.67 \\
\hline \multicolumn{7}{|l|}{ Passenger Aircraft } \\
\hline $\operatorname{RPM}^{\mathrm{d}}\left(10^{9}\right)$ & 277.8 & 344.3 & 410.2 & 487.0 & 668.5 & 3.57 \\
\hline Energy $\left(10^{15} \text { Btu }\right)^{d}$ & 1.697 & 2.103 & 2.331 & 2.532 & 2.723 & 1.91 \\
\hline \multicolumn{7}{|l|}{ General Aviation ${ }^{b}$} \\
\hline Operations (106) & 37.5 & 38.4 & 42.8 & 47.7 & 54.3 & 1.49 \\
\hline Energy (10 15 Btu) & 0.144 & 0.148 & 0.163 & 0.180 & 0.201 & 1.33 \\
\hline \multicolumn{7}{|l|}{ Domestic Freight } \\
\hline \multicolumn{7}{|c|}{ Ton-Miles Traveled (TMT, 109) } \\
\hline Trucks & 1653.3 & 1965.3 & 2201.9 & 2491.7 & 3202.7 & 2.68 \\
\hline Rail & 898.0 & 1075.4 & 1252.1 & 1490.2 & 2068.8 & 3.39 \\
\hline Marine & 893.3 & 911.1 & 898.5 & 912.0 & 998.7 & 0.45 \\
\hline Aire & 1.8 & 2.5 & 3.0 & 3.8 & 5.5 & 4.48 \\
\hline $\begin{array}{l}\text { Pipeline } \\
\text { Total }\end{array}$ & $\begin{array}{r}763.9 \\
4210.3\end{array}$ & $\begin{array}{r}763.1 \\
4717.3\end{array}$ & $\begin{array}{r}749.6 \\
5105.2\end{array}$ & $\begin{array}{r}729.6 \\
5627.3\end{array}$ & $\begin{array}{r}675.7 \\
6951.4\end{array}$ & $\begin{array}{r}-0.49 \\
2.03\end{array}$ \\
\hline \multicolumn{7}{|l|}{ Energy (10 15 Btu) } \\
\hline Trucks & 4.737 & 5.250 & 5.544 & 5.869 & 7.066 & 1.61 \\
\hline Rail & 0.446 & 0.529 & 0.604 & 0.704 & 0.950 & 3.07 \\
\hline Marine & 0.329 & 0.337 & 0.334 & 0.340 & 0.376 & 0.54 \\
\hline Aire & 0.040 & 0.047 & 0.049 & 0.053 & 0.064 & 1.91 \\
\hline Pipeline & 0.657 & 0.676 & 0.722 & 0.733 & 0.696 & 0.23 \\
\hline Total & 6.209 & 6.839 & 7.253 & 7.699 & 9.152 & 1.56 \\
\hline \multicolumn{7}{|c|}{ Energy Intensity $\left(10^{3} \mathrm{Btu} / \mathrm{TMT}\right)$} \\
\hline Trucks & 2.865 & 2.671 & 2.518 & 2.355 & 2.206 & -1.04 \\
\hline Rail & 0.497 & 0.492 & 0.482 & 0.472 & 0.459 & -0.31 \\
\hline Marine & 0.368 & 0.370 & 0.372 & 0.373 & 0.376 & 0.09 \\
\hline Aire & 21.670 & 18.809 & 16.255 & 14.037 & 11.618 & -2.46 \\
\hline Pipeline & 0.860 & 0.886 & 0.963 & 1.005 & 1.030 & 0.72 \\
\hline
\end{tabular}


TABLE S.2 (Cont'd)

\begin{tabular}{|c|c|c|c|c|c|c|}
\hline \multirow[b]{2}{*}{ Item } & \multicolumn{5}{|c|}{ Value, by Year } & \multirow{2}{*}{$\begin{array}{c}\text { Change, } \\
1985-2010 \\
(\% / y r)\end{array}$} \\
\hline & 1985 & 1990 & 1995 & 2000 & 2010 & \\
\hline Other Subsectors $^{b}$ & & & & & & \\
\hline $\begin{array}{l}\text { Energy }\left(10^{15} \mathrm{Btu}\right) \\
\text { Foreign vessels } \\
\text { Military aviation } \\
\text { Rail transit }\end{array}$ & $\begin{array}{l}0.686 \\
0.657 \\
0.014\end{array}$ & $\begin{array}{l}0.619 \\
0.681 \\
0.014\end{array}$ & $\begin{array}{l}0.686 \\
0.681 \\
0.015\end{array}$ & $\begin{array}{l}0.761 \\
0.681 \\
0.015\end{array}$ & $\begin{array}{l}0.928 \\
0.681 \\
0.016\end{array}$ & $\begin{array}{l}1.22 \\
0.15 \\
0.50\end{array}$ \\
\hline
\end{tabular}

a Vehicle-miles traveled.

bNot included in ANL-90 forecast. Values shown are trend extrapolations.

${ }^{\mathrm{C}}$ Revenue passenger-miles.

dIncludes U.S. fuel purchases by forcign flag carriers.

eAll-cargo aircraft only. 
TABLE S.3 Total Energy Consumed by the Transportation Sector, 1985-2010

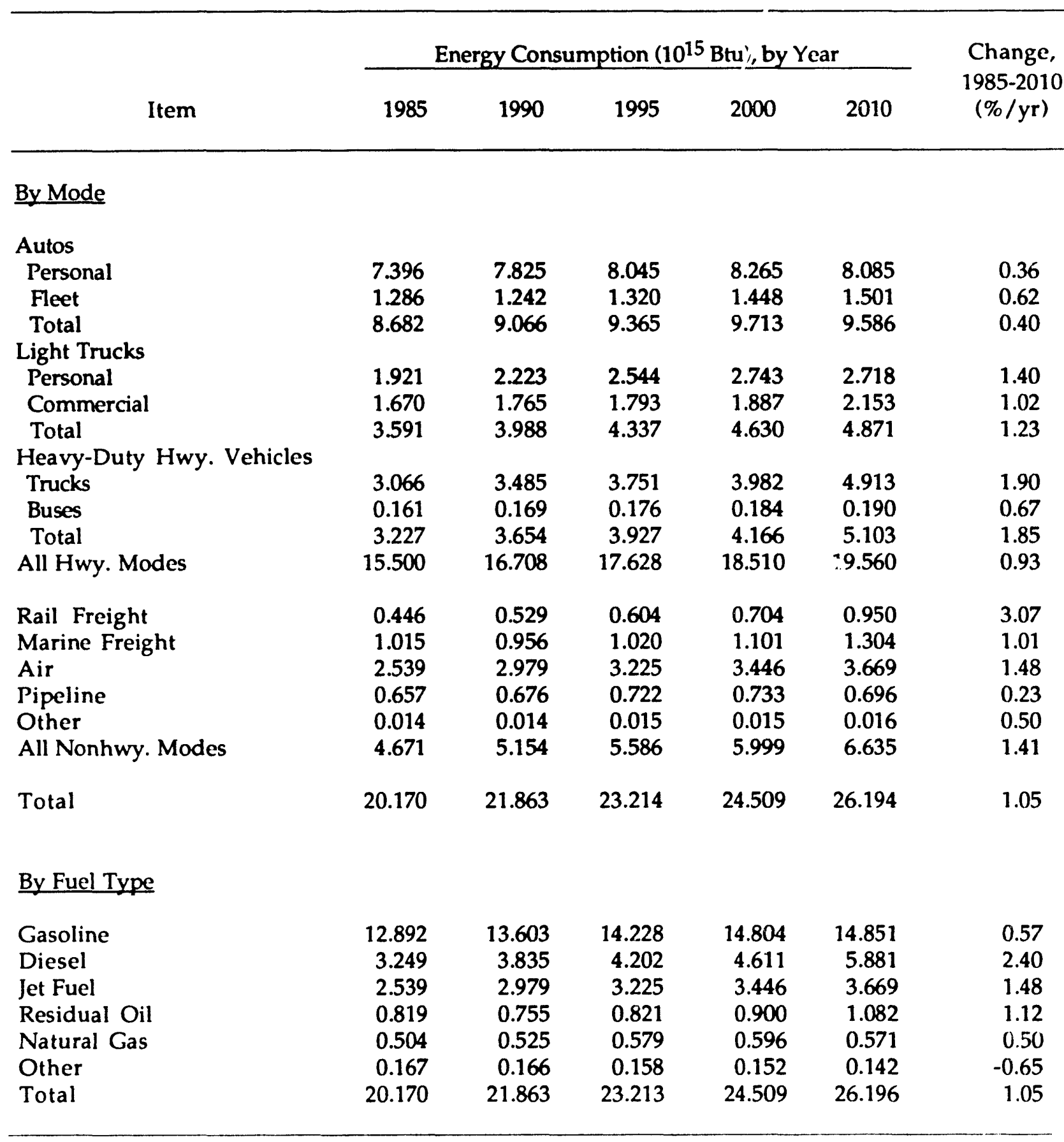


TABLE S.4 Highway Vehicles, Fuel Economy, and Miles Traveled, 1985-2010

\begin{tabular}{|c|c|c|c|c|c|c|}
\hline \multirow[b]{2}{*}{ Item } & \multicolumn{5}{|c|}{ Value, by Year } & \multirow{2}{*}{$\begin{array}{c}\text { Change, } \\
1985-2010 \\
(\% / y r)\end{array}$} \\
\hline & 1985 & 1990 & 1995 & 2000 & 2010 & \\
\hline \multicolumn{7}{|l|}{ Vehicles $\left(10^{6}\right)$} \\
\hline \multicolumn{7}{|l|}{ Autos } \\
\hline Personal & 122.3 & 140.4 & 150.6 & 161.5 & 184.7 & 1.66 \\
\hline Fleet & 8.9 & 9.2 & 9.9 & 10.8 & 13.0 & 1.52 \\
\hline Total & 131.2 & 149.6 & 160.6 & 172.3 & 197.7 & 1.66 \\
\hline \multicolumn{7}{|l|}{ Light Trucks } \\
\hline Personal & 23.5 & 29.6 & 35.4 & 39.6 & 44.6 & 2.59 \\
\hline Commercial & 12.0 & 13.6 & 14.7 & 16.2 & 19.6 & 1.96 \\
\hline Total & 35.6 & 43.2 & 50.2 & 55.8 & 64.2 & 2.39 \\
\hline Heavy Trucks & 5.3 & 6.1 & 6.6 & 7.3 & 9.2 & 2.21 \\
\hline \multicolumn{7}{|l|}{ Fuel Economy (mpg) } \\
\hline Autns & 18.2 & 20.0 & 20.7 & 21.3 & 24.7 & 1.24 \\
\hline Light Trucks & 13.0 & 14.2 & 14.9 & 15.4 & 17.0 & 1.08 \\
\hline Personal & 13.6 & 15.0 & 15.4 & 15.8 & 17.7 & 1.05 \\
\hline Commercial & $12 . n$ & 13.3 & 14.3 & 15.0 & 16.0 & 1.09 \\
\hline Heavy Trucks & 5.8 & 5.9 & 6.1 & 6.4 & 6.6 & 0.52 \\
\hline Medium & 8.0 & 8.1 & 8.2 & 8.3 & 8.4 & 0.21 \\
\hline Lt.-Heavy & 6.9 & 7.0 & 7.2 & 7.3 & 7.4 & 0.31 \\
\hline Heavy-Heavy & 5.4 & 5.6 & 5.7 & 6.1 & 6.3 & 0.60 \\
\hline All Trucks & 10.6 & 11.6 & 12.2 & 12.7 & 13.6 & 1.00 \\
\hline \multicolumn{7}{|c|}{ Vehicle-Miles Traveled $\left(10^{9}\right)$} \\
\hline Autos & 1262.5 & 1446.5 & 1546.4 & 1656.9 & 1894.7 & 1.64 \\
\hline \multicolumn{7}{|l|}{ Light Trucks } \\
\hline Personal & 209.3 & 266.0 & 312.9 & 345.4 & 384.9 & 2.47 \\
\hline Comml. Gasoline & 157.9 & 180.3 & 196.4 & 215.4 & 258.9 & 2.00 \\
\hline Comml. Diesel & 4.7 & 6.5 & 7.7 & 9.3 & 14.9 & 4.73 \\
\hline Total & 371.8 & 452.8 & 517.0 & 570.1 & 658.6 & 2.31 \\
\hline \multicolumn{7}{|l|}{ Heavy Duty Vehicles } \\
\hline Gas Trucks & 39.3 & 37.2 & 36.7 & 35.9 & 37.2 & -0.22 \\
\hline Diesel Trucks & 91.9 & 115.6 & 130.5 & 150.3 & 199.7 & 3.15 \\
\hline Buses & 6.3 & 6.7 & 7.0 & 7.4 & 7.7 & 0.81 \\
\hline Total & 137.5 & 159.4 & 174.1 & 1932.6 & 244.6 & 2.33 \\
\hline Total, All Vehicles & 1771.8 & 2058.7 & 2237.5 & 4159.6 & 2797.9 & 1.84 \\
\hline
\end{tabular}




\section{INTRODUCTION}

Since 1979, the Center for Transportation Research (CTR) at Argonne National Laboratory (ANL) has produced baseline projections of U.S. transportation activity and energy demand. These projections and the methodologies used to compute them are documented in a series of reports and research papers. ${ }^{1-9}$ As the latest in this series of projections, this report documents the assumptions, methodologies, and results of the most recent projection -- termed ANL-90N -- and compares those results with other forecasts from the current literature, as well as with a selection of earlier Argonne forecasts.

\subsection{PURPOSE}

This report and the projections it contains were developed for the U.S. Department of Energy's Office of Transportation Technologies (OTT). The report is intended to serve as a reference document, providing a comprehensive set of transportation projections for use by OTT staff and other parties involved in developing or evaluating transportation conservation programs or in studying general issues in transportation energy demand. Specifically, the projections can aid in program development by identifying modes and submodes that show rapidly growing energy demand; they can assist in program evaluation by providing a baseline against which to assess the impact of ongoing conservation efforts; and they can provide a detailed, consistent forecast for use in other studies.

While every effort has been made to be all-inclusive, the projections are not completely comprehensive. Time and modeling effort have been focused on the major energy consumers -- automobiles, trucks, commercial aircraft, rail and waterborne freight carriers, and pipelines. Because buses, rail passenger services, and general aviation consume relatively little energy, they are projected in the aggregate, as "other" modes, and used primarily as scaling factors. These projections are also limited to direct energy consumption. Projections of indirect energy consumption, such as energy consumed in vehicle and equipment manufacturing, infrastructure, fuel refining, etc., were judged outside the scope of this effort.

\subsection{CONTENTS AND ORGANIZATION}

The Transportation Energy and Emissions Modeling System (TEEMS) links several disaggregate models to produce an aggregate forecast of transportation activity, energy use, and emissions. Because the component models are disaggregate, discussions of TEEMS's methodologies and results may be structured in any number of ways. For simplicity, modeling procedures and results for passenger modes are discussed separately from those for freight modes.

This report is organized into four chapters. Following the introduction, which briefly describes the report and outlines the general features of the baseline scenario, Secs. 2 
and 3 describe the TEEMS components used to generate the passenger and freight forecasts, discuss input assumptions, and present energy and activity projections for each major mode. Passenger and freight modes are discussed separately because methodologies and input assumptions split naturally along those lines. Within passenger modes, personal and fleet automobiles are discussed separately in Sec. 2, then combined in Sec. 4 as modal and submodal results integrated into a forecast whole. Section 4 also discusses the sensitivity of the various models to varying demographic and fuel price assumptions and compares the results with those of other forecasts. Two appendixes are included. Appendix A presents input data and results of the 1985 recalibration of the freight sector submodel (FRATE) within TEEMS. Appendix B presents information, in comparable detail, on the personal travel and vehicle ownership projection submodels (DPTAM and VOP).

\subsection{BASELINE SCENARIO}

This latest projection - like all the preceding projections -- is based upon a "businessas-usual" scenario. In other words, the continuation of current trends is assumed. Examples of such trends include consumer preferences for particular vehicle-size classes or fuel types, the travel rates of households defined on the basis of common demographic characteristics, and vehicle scrappage rates. Such discontinuities as war, depression, or major social change cannot be considered within the framework of such a scenario. Lowprobability, high-impact events may have profound and lasting effects on travel and vehicle ownership rates, vehicle preferences, and lifestyles, but forecasting their effects is both expensive (in terms of the number of scenarios that would have to be considered) and highly uncertain. On the other hand, the impacts of assumptions about such key inputs as fuel price, demographic characteristics, and economic conditions can be explored by postulating alternative scenarios and conducting sensitivity analyses. See Secs. 3 and 4 for further discussions of these topics.

\subsubsection{Economic and Demographic Assumptions}

Consistency is a primary concern in the present project. Consistency is defined quite broadly - both internally, among the various components of the ANL-90N projection, and externally, compared with the input assumptions of other DOE projections. To achieve consistency, all submodels in TEEMS incorporate a common set of economic and demographic assumptions, which also reflect the reference case of the January 1989 National Energy Policy Plan (NEPP). ${ }^{10}$ Because of this relationship to NEPP, the identifier "N" has been subjoined to the forecast.

Since 2010 is the horizon year of the NEPP projections, average annual growth rates from the preceding 10-year period were used to extrapolate to the year 2020. Extrapolation was also used to extend input assumptions for the number of households and key household demographic distributions. Economic and fuel price variables were extended by 
a special run of the Data Resources, Inc. (DRI), macromodel of the U.S. economy. ${ }^{11}$ Table 1.1 lists key economic, demographic, and fuel-price assumptions and their sources. ${ }^{10-14}$ Table 1.2 provides distributions of the demographic attributes used in forecasting household vehicle ownership and travel demand.

As shown in Tables 1.1 and 1.2, steadily rising real household incomes accompanied by moderate economic growth are assumed for the baseline forecast. World oil prices remain relatively stable in the near term. Beyond the year 2000, oil prices rise more rapidly, eventually surpassing the peak levels experienced in 1981, although still well below the forecasts generated in the early 1980s. Average household size continues to decline, although at a slower rate than in the recent past, while the number of licensed drivers per household rises through 2010, then drops as "baby boomers" reach retirement age.

\subsubsection{Transportation Technology Assumptions}

In the baseline scenario, transportation technologies continue to experience evolutionary improvements. However, no dramatic breakthroughs -- in engines, batteries, or fuels -- are assumed to occur. Specific assumptions are as follows:

- The four-stroke internal combustion engine (ICE) remains the dominant power plant for highway vehicles. While researck, continues on alternative power plants for light- and heavy-äity vehicles, the combination of relatively low fuel prices and a lack of regulatory incentives discourages an all-out effort to develop new, more fuel-efficient $\epsilon$ ngines. Two-stroke engines that achieve $15 \%$ better fuel economy than conventional technology engines are introduced after the turn of the century, but because of consumer preferences for larger, more powerful vehicles, their penetration is limited to less than $5 \%$ of vehicles and is confined primarily to niche markets (e.g., small commuter vehicles that account for less than $20 \%$ of all personal vehicles).

- Evolutionary improvements in the fuel efficiency of light-duty vehicles occur primarily from continued advances in electronics, aerodynamics, material substitution (and corresponding engine downsizing), and fuel delivery. 15,16 Electronics continue to improve the efficiency of engines, transmissions, and fuel systems as multiport fuel injection, knock limiters, and electronic transmission controls become the norm; the "aero" look proliferates, lowering the average drag coefficient of the fleet to approximately 0.3 and increasing fuel economy by some $3.5 \%$. Greater use of lighter-weight materials -- including plastics, magnesium, ceramics, and high-strength, lowalloy steels -- permits some engine downsizing. However, because of market demand for higher horsepower and torque, the principal effect is to stabilize engine size and fuel efficiency. 
TABLE 1.1 Economic and Demographic Assumptions, 1985-2020

\begin{tabular}{|c|c|c|c|c|c|c|}
\hline \multirow[b]{2}{*}{ Variable } & \multicolumn{5}{|c|}{ Year } & \multirow[b]{2}{*}{ Source } \\
\hline & 1985 & 1995 & 2000 & 2010 & 2020 & \\
\hline Population (106) & 239.3 & 260.1 & 268.3 & 282.6 & 294.4 & Ref. 12 \\
\hline Households $\left(10^{6}\right)$ & 86.8 & 100.3 & 105.9 & 115.4 & 128.4 & Ref. 13 \\
\hline GNP $\left(10^{9} 1988 \$\right)$ & 4,553 & 5866 & 6,622 & 8,559 & 10,364 & Ref. 11 \\
\hline $\begin{array}{l}\text { GNP growth } \\
(\% / \mathrm{yr})\end{array}$ & & 2.57 & 2.45 & 2.60 & 1.93 & Ref. 11 \\
\hline $\begin{array}{l}\text { Average } \\
\text { household } \\
\text { income (1988 \$) }\end{array}$ & 31,810 & 34,953 & 37,011 & 41,957 & 43,967 & Ref. 11 \\
\hline $\begin{array}{l}\text { World oil price } \\
\text { (\$/bbl, } 1988 \$)\end{array}$ & 29.44 & 21.23 & 28.89 & 45.16 & 48.74 & Refs. 10,14 \\
\hline $\begin{array}{l}\text { Gasoline price } \\
(\$ / \text { gal, } 1988 \$)\end{array}$ & 1.23 & 1.14 & 1.27 & 1.60 & 2.05 & Refs. 10,14 \\
\hline $\begin{array}{l}\text { Diesel price } \\
\text { (\$/gal, } 1988 \$)\end{array}$ & 1.14 & 0.95 & 1.16 & 1.61 & 2.25 & Refs. 10,14 \\
\hline $\begin{array}{l}\text { Jet fuel price } \\
(\$ / \text { gal, } 1988 \$)\end{array}$ & 0.87 & 0.65 & 0.88 & 1.37 & 1.75 & Refs. 10,14 \\
\hline
\end{tabular}

- The fuel economy of the commercial truck fleet improves as a result of continued advances in aerodynamics, increased penetration of electronic engine and transmission controls, and improved tires and lubricants. Diesels achieve full penetration of vehicle classes 7 and 8 and increase their share of classes 1-6.

- To a large extent, improvements in the fuel efficiency (and emissions) of highway vehicles are offset by continued increases in traffic congestion and the large number of older, less efficient vehicles that remain on the road. Although user-fee revenues grow with relatively stable vehicle fuel efficiency (and provide adequate funds for highway maintenance), revenues are insufficient to support major capacity additions. Thus, congestion increases 
TABLE 1.2 Distributions of Households by Demographic Attribute, 1985-2020

\begin{tabular}{|c|c|c|c|c|c|}
\hline \multirow[b]{2}{*}{ Attribute } & \multicolumn{5}{|c|}{ Percentage, by Year } \\
\hline & 1985 & 1995 & 2000 & 2010 & 2020 \\
\hline \multicolumn{6}{|c|}{ Residential location ${ }^{a}$} \\
\hline Central city & 32.6 & & & & \\
\hline Suburbs & 32.8 & & & & \\
\hline Rural & 34.6 & & & & \\
\hline \multicolumn{6}{|l|}{ Income $(1988 \$)^{b}$} \\
\hline$<\$ 12,500$ & 25.9 & 23.0 & 22.3 & 19.0 & 18.0 \\
\hline$\$ 12,500-30,000$ & 38.1 & 37.5 & 37.0 & 34.0 & 31.0 \\
\hline$\$ 30,001-50,000$ & 21.7 & 23.7 & 23.8 & 27.0 & 29.0 \\
\hline$>\$ 50,000$ & 14.3 & 15.8 & 16.9 & 20.0 & 22.0 \\
\hline \multicolumn{6}{|c|}{ Age of householder (yr) } \\
\hline$<35$ & 29.3 & 24.2 & 21.2 & 17.7 & 16.5 \\
\hline $35-44$ & 20.1 & 23.8 & 23.9 & 19.5 & 15.8 \\
\hline $45-64$ & 29.6 & 30.2 & 33.5 & 37.4 & 38.0 \\
\hline$\geq 65$ & 20.9 & 21.8 & 21.4 & 25.3 & 29.8 \\
\hline \multicolumn{6}{|l|}{ Household size } \\
\hline 1 & 23.7 & 25.5 & 26.5 & 28.0 & 32.0 \\
\hline 2 & 31.6 & 33.0 & 33.0 & 33.0 & 32.5 \\
\hline 3-4 & 33.5 & 33.5 & 33.5 & 33.5 & 31.0 \\
\hline$\geq 5$ & 11.2 & 8.0 & 7.0 & 5.5 & 4.5 \\
\hline \multicolumn{6}{|l|}{ Licensed drivers } \\
\hline 0 & 7.2 & 5.5 & 5.0 & 4.5 & 4.5 \\
\hline 1 & 26.2 & 26.0 & 26.0 & 26.0 & 32.3 \\
\hline 2 & 52.5 & 55.0 & 56.0 & 57.0 & 52.0 \\
\hline$\geq 3$ & 14.1 & 13.5 & 13.0 & 12.5 & 11.2 \\
\hline
\end{tabular}

aValues shown for 1985 are constant for all years.

bRanges approximated to 1988 dollars. 
faster than total highway travel, since population growth continues to vary by and within regions and a greater proportion of travel occurs is urban areas. Furthermore, the variation between the estimated fuel economy of new cars (as computed in EPA tests) and the actual fuel economy of the entire automotive fleet rises steadily.

- Increased congestion and extended equipment life cycles (due to historically high real interest rates) depress the potential for fuel-efficiency improvements to commercial trucks and aircraft and account for a wider gap between manufacturers' claims and the in-service efficiency of these fleets.

- The fuel efficiency of commercial aircraft continues to improve as a result of evolutionary changes in engines and inflight operations, materials substitution, and the retirement of older aircraft. Specific technologies include advanced electronic controls to optimize fuel burn under given flight conditions and composite structures, including metal matrix materials, to reduce weight and increase efficiency. In the longer term, higher jet fuel prices bring further improvements in compressor and turbine efficiencies, additional materials substitution, and the development of active controls to optimize aerodynamics. The average number of seats per aircraft continues to rise, although at a declining rate (from 111 in 1970, to 161 in 1987, to approximately 200 by 2010), and load factors stabilize.

- Long vehicle life cycles and low fuel costs (as a portion of total operating costs) provide little incentive for fuel-efficiency improvement in the rail and marine modes. Thus, the energy intensities for these modes improve only marginally.

- Although gasoline properties change somewhat in response to air quality concerns, the fuel retains its dominance in the light-duty sector. Diesel penetration increases for light-duty vehicles in commercial applications, but it remains virtually absent from the personal vehicle fleet. Methanol and other alternative fuels are not included in the baseline scenario.

\subsubsection{Transportation Policy Assumptions}

In the baseline scenario, such environmental issues as global warming, acid rain, and air quality continue to draw considerable research interest and stir political debate, but conflicts among industrial, regional, and other interest groups combine to prevent formation of a broad-based coalition supporting strong environmental actions. Thus, no new environmental policy initiatives are implemented. Specifically, travel and development restrictions are not imposed on metropolitan areas that fail to attain the standards mandated under the Clean Air Act, fuel-economy standards are not raised, carbon taxes are not enacted, and fuel taxes are not increased from current real levels. Clearly, if such initiatives were included in the baseline scenario, the use of alternative fuels would 
rise substantially, new technologies would enter the marketplace earlier and penetrate faster, and fuel consumption would decline.

Also, no changes are assumed for the baseline scenario in metropolitan development patterns, public transportation funding, fuel availability, monetary modal travel costs (e.g., user fees, taxes, vehicle registration). 


\section{PROJECTION METHODOLOGY AND RESULTS: PASSENGER MODES}

Passenger modes include personal vehicles (automobiles and light trucks), fleet automobiles, commercial aviation, and a number of modes considered "minor" from the standpoint of energy use (e.g., transit, school, and intercity buses; AMTRAK; and rail transit). Within TEEMS, each of these modes is handled separately.

\subsection{PERSONAL VEHICLES}

\subsubsection{Methodology}

The TEEMS component that forecasts personal vehicle use is driven by demographic, economic, and technological changes. Households are disaggregated by six attributes, each of which is further disaggregated into three or four sub-categories. The six attributes and the methods used to forecast their future distributions are as follows:

1. Location (three categories). The distribution of households by residential location [within central cities of existing standard metropolitan statistical areas (SMSAs), in suburbs of those areas, or in rural areas] was held constant for all years. Because new SMSAs are likely to be designated, this actually implies an increase in the urban share of the population.

2. Income (four categories). Future-year distributions of households by income category were developed from projections of personal income produced by the DRI macromodel.

3. Age of householder (four categories). Distributions by age of householder were developed by ANL from projections by the Bureau of the Census.

4. Household size (four categories). Average household size was estimated from the population and household projections and used to develop distributions of households by household size.

5. Number of drivers (four categories). The base-year (1985) distribution of households by number of drivers was updated to reflect a gradual increase in the percent of licensed drivers in the driving-age population.

6. Number of vehicles (four categories). The distribution of households by number of vehicles owned was left uncontrolled for the model to determine. 
After future or target distributions ("margins") of households by each attribute have been prepared (see Table 1.2), an iterative proportional fitting (IPF) technique is used to generate a new matrix of household totals consistent with the exogenously developed targets. This technique can also be used to update old surveys to a new set of control totals. ${ }^{17}$ Figure 2.1 illustrates the operation of the technique on a base-year matrix consisting of household counts from a sample survey, along with associated household weights or multipliers used to expand the sample to national totals, and target margins specifying the future distribution of total households in terms of each attribute. The IPF algorithm ensures that future-year household weights will be consistent with the demographic projections of the baseline forecast to produce a future-year matrix of household totals.

A vehicle ownership model is then applied to project changes in the number of vehicles owned in some future year by each cell in the matrix. Personal vehicle ownership rates have risen substantially over the last two decades. The total number of registered personal vehicles (automobiles and light trucks) grew by $56.9 \%$ between 1970 and 1984, while the number of households grew by only $34.7 \%$. Thus, ownership per household in:reased despite a decrease in averaģe household size (from 3.22 to 2.77). Ownership rates rose by $33.3 \%$ on a per-capita basis, but by only $11.4 \%$ on a per-driver basis. The relatively modest growth in ownership fer licensed driver was due to rapid demographic shifts (i.e., the entry of the last "baby boom" cohorts into the driving-age population) that increased the number of licensed drivers by $48.4 \%$ between 1970 and 1989 (to $86.7 \%$ of the driving-age population). At the same time, another key factor in vehicle ownership, per-capita disposable income, rose by $20 \%$ (from $\$ 9,069$ to $\$ 10,887$ in 1984 dollars), thereby increasing the affordability of additional vehicles. In order to capture these trends and relationships, our vehicle ownership model first forecasts ownership per driver and then applies this rate to households, using the above-mentioned categories of the attribute "number of drivers."

Model inputs include number of licensed drivers, disposable income, and annual fuel cost. The model estimates an affluence-induced ownership rate that would be achieved if income and operating cost were the only determinants and the process of vehicle acquisition and disposal did not impose a "time cost." A calibration factor then adjusts ownership to match observed rates. The target, or affluence-induced, rate of vehicle ownership per licensed driver $\left(T_{t}\right)$ is estimated as follows:

$$
\mathrm{T}_{\mathrm{t}}=\mathrm{b}_{0}+\mathrm{b}_{1} \ln \mathrm{YDC}_{\mathrm{l}-1}+\mathrm{b}_{2} \ln \left(\frac{\mathrm{VMT}_{\mathrm{t}-1} \mathrm{G}_{\mathrm{t}-1}}{\mathrm{MPG}_{\mathrm{t}-1}}\right)
$$

where:

$$
\begin{aligned}
\mathrm{YDC} & =\text { per-capita disposable income }\left(10^{3} 1984 \$\right), \\
\mathrm{VMT} & =\text { annual miles per vehicle, } \\
\mathrm{G} & =\text { average price of a gallon of fuel }(1984 \$), \\
\mathrm{MPG} & =\text { fuel economy of household vehicles (miles per gallon), and } \\
\mathrm{b}_{0}, \mathrm{~b}_{1}, \mathrm{~b}_{2} & =\text { model parameters. }
\end{aligned}
$$




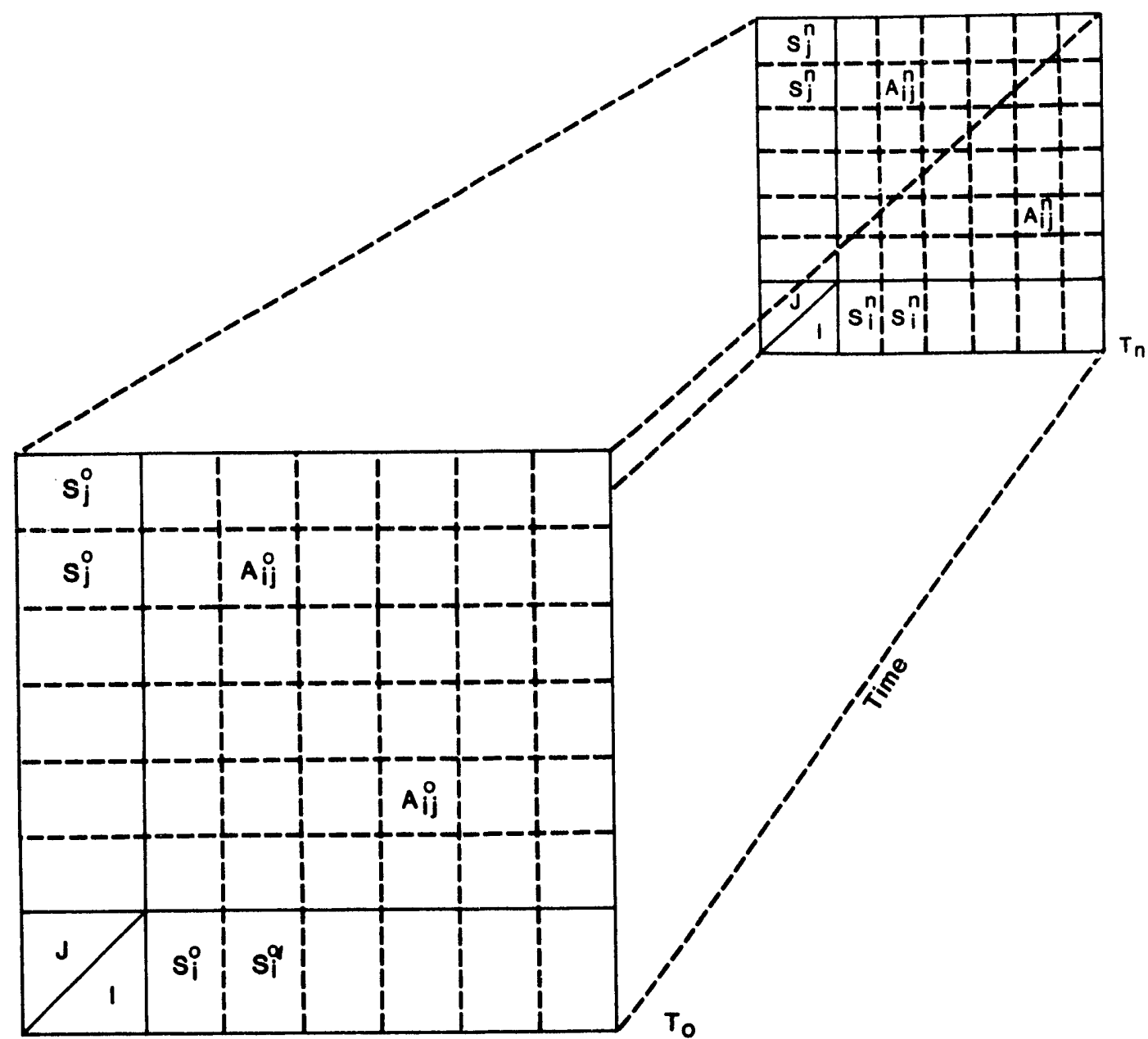

$A_{i j}^{n}=S_{j}^{n} / S_{j}^{\circ} A_{i j}^{\circ}$
$A_{i j}^{n}=S_{i}^{n} / S_{i}^{\circ} A_{i j}^{0}$
$w_{i j}^{n}=A_{i j}^{n} / A_{i j}^{0} \quad W_{i j}^{\circ}$

where:

$A_{i j}=$ Original cell total

$s_{i}^{n} s_{j}^{n}=$ Target margins for categories $i$ and $j$ in margins $I$ and $J$

$S_{i} S_{j}^{0}=$ Sample margins for categories $i$ and $j$ in margins $I$ and $J$

$A_{i j}=$ Forecast cell total

$W_{i j}=$ Original household weight

$W_{i j}=$ Forecast household weight

FIGURE 2.1 Iterative Proportional Fitting over Time, Two-Margin Case 
The model estimates the annual rate of change $\left(R_{t}\right)$ in household vehicle ownership from the preceding year $\left(\mathrm{HHV}_{\mathrm{t}-1}\right)$ as:

$$
R_{t}=\frac{\left(T_{t} D_{t}-H H V_{t-1}\right) a}{H H V_{t-1}}
$$

where:

$$
\begin{aligned}
T_{t} & =\text { the affluence-induced, or target, rate, } \\
D_{t} & =\text { the number of licensed drivers, and } \\
a & =\text { calibration factor. }
\end{aligned}
$$

The total number of household vehicles in year $t$ is then given by:

$$
H H V_{t}=\left(1+R_{t}\right) H H V_{t-1}
$$

The target rate was estimated from Eq. 1 using time-series data for the period 19701984. Parameters $b_{0}, b_{1}$, and $b_{2}$ were estimated at 0.88 [standard error $(S E)=0.02$ ], 0.268 $(\mathrm{SE}=0.11)$, and -0.083 ( $\mathrm{SE}=0.057$ ), respectively. ${ }^{*}$ The calibration factor $(\mathrm{a})$ was estimated at 0.33. The equation projected total household vehicle registrations within $2-3 \%$ of actual values when applied to 1970-1984 data.

The IPF algorithm assigns households to vehicle ownership classes (i.e., 0, 1, 2, or $\geq 3$ ) such that the input margins of the other five attributes are matched. The resulting matrix reflects the socioeconomic scenario being simulated for the first five attributes. The vehicle ownership raies generated by IPF carry forward all base-year relationships between the first five attributes and vehicles owned. To reflect the newly computed vehicle ownership rates (see above) within the household matrix, households must be reassigned to the four vehicle classes. This reassignment should not alter the distribution within the other five attributes.

The reassignment problem is solved using Lagrange mulipliers. The cieviation between the IPF-generated and the revised household matrix is minimized subject to conditions that (1) the sum of households remains unchanged, (2) the number of households assigned to each cell is a positive number (or zero), and (3) the total number of vehicles rep: sented by the revised matrix reflects the new vehicle ownership rate.

Next, the composition of the stock of household vehicles is estimated by type and siza using a vehicle stock allocation model. Currently, only two vehicle types automobiles and light trucks -- are considered by this model. Within each type, several vehicles -- characterized by size, fuel, and technology -- may be defined. The size classification is usually related to interior volume and/or seating capacity. In the ANL-90N

\footnotetext{
"Historically, fuel price has not had a strong impact on household vehicle ownership. This is reflected in the standar' 1 error of parameter $b_{2}$ in Eq. 1. The parameter is retained to permit analysis of alternative fuel price and energy tax assumptions.
} 
forecast, vehicle sizes are: small, midsize, and large automobile; compact truck; standard truck; minivan/small utility; and standard van/large utility. Fuel type may be gasoline, diesel, alcohol, compressed natural gas, or any other. Vehicles may also be identified by engine technology (e.g., stratified charge, Brayton, fuel cell, etc.). A set of vehicle characteristics is developed to reflect the socioeconomic, technological, and policy conditions of the scenario, and the resulting vehicle menu is input to the model.

The vehicle choice model treats vehicle selection as a function of vehicle characteristics (utility-supplied) and household "needs" (utility-demanded or afforded). Vehicles are characterized by price, operating cost, seating capacity, curb weight, horsepower, and fuel economy (the last is included to project travel and fuel consumption). Household needs are determined by both the demographic makeup of the household and the intensity of vehicle use (in miles per vehicle). Household demographic attributes are contained in the input household matrix (already disaggregated by the six attributes described above), while vehicle usage is computed within the model as a function of income, number of licensed drivers, and number of vehicles. An incremental logit formulation is used. The incremental formulation projects changes in the base-year vehicle ownership probabilities, given base- and future-year vehicle characteristics. Within the incremental formulation, changes in the utility of a vehicle are applied to that vehicle's base-year ownership probability, and this new probability is then normalized so that all probabilities sum to one.

The vehicle operating costs considered by the vehicle choice model are disaggregated into fuel and nonfuel components. The fuel component is computed using a vehicle-age distribution and estimated fuel economy for each vintage. Future-year fuel economies are developed using the econometric model described below. This model projects aggregate fuel economy for all household vehicles. Historical relationships between different sizes of vehicles are used to estimate fuel economy by vehicle size. Vehicles introduced during the analysis period are characterized using published research and independent analysis.

As mentioned above, fuel economies are also used to compute energy consumption by household vehicles. A set of vehicle utilization rates [i.e., vehicle-miles traveled (VMT) per vehicle] was developed (one for each cell of the household matrix) using the 1983 Nationwide Personal Transportation Study (NPTS). This approach is preferred over an equation for projecting these rates by location, income, drivers, and vehicles because the relationship between these attributes and vehicle utilization is still not clear. To illustrate this point, it should be noted that very little change in VMT per vehicle occurred between the last two NPTS surveys, despite significant increases in income, drivers, and vehicles and substantial population shifts. ${ }^{18,19}$

The fuel economy estimates used within TEEMS to compute energy consumption by each type of household vehicle and to calculate the fuel portion of each vehicle's operating cost are developed exogenously. Two approaches are available to produce such estimates. In the first approach, each vehicle type is characterized in terms of parameters known to influence fuel consumption (e.g., weight, acceleration, drag coefficient, engine technology); disaggregate fuel economy is estimated from historical engineering, relationships;20,21 and aggregate or fleetwide fuel economy is then computed as a weighted harmonic mean. In 
the second approach, aggregate fuel economy is estimated directly with a model based on past experience. The second approach was selected for this project.

The Greenhouse Gas Transportation Energy Estimation Model (GGTEM), an econometric model based on expenditure allocation research at Argonne National Laboratory, 22,23 was used to compute aggregate fuel economy of household automobiles. The GGTEM uses a set of interlinked econometric models to estimate average household vehicle ownership, new- and used-car price indexes, average vehicle age, new-car fuel economy, and on-road fuel economy. The model estimates new-car fuel economy as a function of changes in (1) fuel price, (2) the share of household vehicles accounted for by large cars, and (3) corporate average fuel economy (CAFE) standards. The equation for computing new-car fuel economy was recently revised to reflect new research findings. ${ }^{24}$ On-road fuel economy is computed from a chi-square age distribution (calculated from historical relationships to average age), which in turn is dependent on income and car price indexes. The effect of urban traffic congestion on fuel economy is captured by using a set of performance degradation factors. 25,26

The year-specific fuel economy computed by GGTEM is input to the TEEMS vehicle stock allocation model. A menu of vehicles is prepared using this value as a target or guide. Since household size, the number of vehicles owned, fuel price, performance criteria, and income determine the size distribution of household vehicles projected by TEEMS, the VMT-weighted fuel economy generated within TEEMS differs from the unweighted value computed by GGTEM. The TEEMS-generated household activity projections are then supplied to a fuel consumption module and an emissions estimation module. The fuel consumption module uses vehicle fuel economy, fuel price, and an exogenous estimate of household price elasticity to project consumption by type of fuel. Because emissions are beyond the scope of this document, TEEMS's projections of hydrocarbon, nitrogen oxides, and carbon monoxide emissions are not reported here. Carbon dioxide emissions, which can be calculated as a direct function of consumption by type of fuel, are not reported either.

\subsubsection{Input Assumptions}

Economic and demographic assumptions were summarized in Tables 1.1 and 1.2. Technology assumptions, translated into the input parameters of the Disaggregate Vehicle Stock Allocation Model (DVSAM), are presented in Table 2.1.

\subsubsection{Results}

Projected changes in new-car fuel economy result from the terms in Eq. 1 that estimate new-vehicle manufacturers' short-term (one to three years) and long-term (up to seven years) reactions to gasoline price changes. When gasoline price rises, the fuel economy of new cars is projected to rise; when gasoline price falls, fuel economy is also 


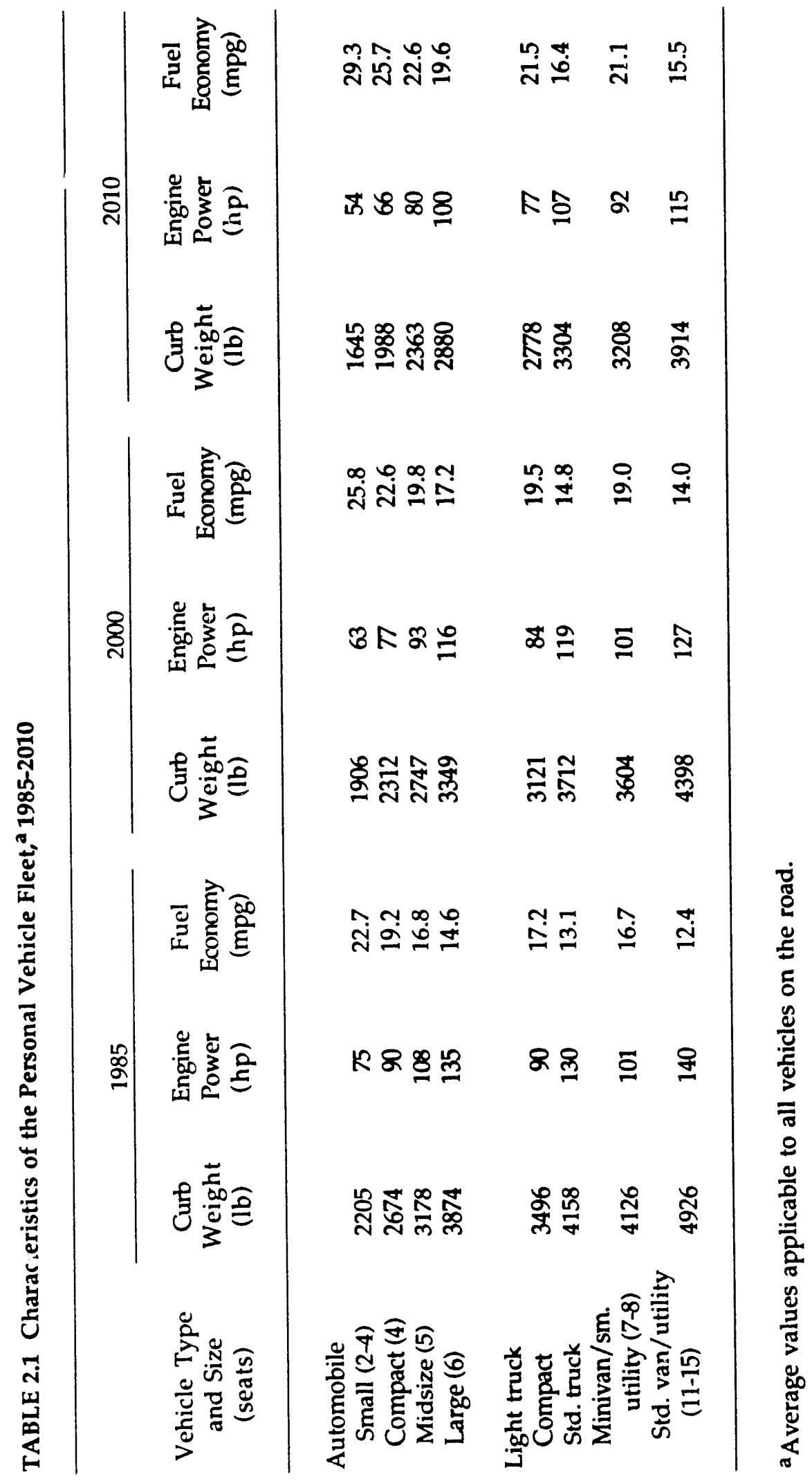


projected to fall, unless constrained by CAFE or other regulations. This latter effect is exactly what has happened in the past several years among those makers of light duty vehicles (primarily imports) not constrained by CAFE to increase fuel economy. $24,27,28$

Equation 1 excludes a trend term, which would have projected a steady improvement in fuel efficiency due to long-term technical change. Such improvement may have occurred in the past as a direct effect of tighter CAFE standards and environmental regulations, or an indirect effect as manufacturers responded strategically to perceived consumer preferences and potential future regulations. The effects of CAFE standards and consumer preferences are captured in the above-discussed reaction to price changes; the effect of environmental regulations was not examined in this project. Although environmental regulations can lower fuel economy in the short run, over the longer term they can also spur manufacturers to improve their understanding of the combustion process in order to reduce emissions by more complete burning of fuel. For passenger cars, the trend term would have increased new-car fuel economy by approximately five miles per gallon in 2010. By deleting this term, we assume that there are no new pressures on manufacturers from energy or environmental regulations.

Our models translate new-car fuel efficiency, as rated by EPA, into an estimate of the fuel efficiency realized when the entire fleet is driven on the road. Patterson and Westbrook ${ }^{26}$ have shown that increased congestion has slowed average trip speed and wianed the margin between the EPA-rated and on-road fuel economy of new vehicles. The Federal Highway Administration projects continued increases in congestion in its future scenarios. ${ }^{29}$ We assume a continued worsening of the congestion problem in our base case, with the gap between EPA-rated and on-road fuel economy of new vehicles widening from about $12 \%$ in the 1970 s to $30 \%$ by 2010.26 Solving the congestion problem will require heavy investments in new highway infrastructure and might only be accomplished with some degree of access control. Los Angeles, Orlando (Florida), and several other U.S. cities are currently working on "smart highways" as a strategy to combat congestion and reduce vehicle emissions. A 1982 European study ${ }^{30}$ showed that congestion (low trip speed) has a pronounced effect on fuel consumption, giving further credibility to Patterson's prediction. Since that study was completed, Europe has initiated "Prometheus," a comprehensive program to develop intelligent highway and vehicle systems and sophisticated traffic controls to reduce congestion. ${ }^{31}$

Tables 2.2-2.4 present the ANL-90N projections of personal vehicle stocks, activity, and fuel use by type and size class. Since the original $27.5-\mathrm{mpg}$ standard for new domestic passenger cars has been reinstated, in our base case we assume that new-car fuel efficiency will achieve this level in 1989. However, the model predicts a $1.5 \% / \mathrm{yr}$ deterioration in new-car fleet fuel economy from 1989 to 1992. This deterioration is consistent with recent trends. Oak Ridge National Laboratory ${ }^{28}$ estimates indicate that the miles-per-gallon rating of the new "foreign-owned" imported car fleet has declined by an average of $1.3 \%$ /yr since 1983 (light trucks by 3.85\%/yr since 1984), that the fuel economy of "transplant and joint venture" U.S. manufactured cars has declined by $2.4 \% /$ yr since 1981 (light trucks by $3.9 \% / y r$ since 1984), and that the fuel economy of "captive imports" manufactured abroad has declined by $3.5 \% /$ yr since 1986 (light trucks by $2.0 \% /$ yr since 1984 ). 
TABLE 2.2 Personal Vehicles by Type and Size Class, ANL-90N

\begin{tabular}{lrrrr}
\hline & \multicolumn{3}{c}{ Year } & $\begin{array}{c}\text { Change, } \\
\text { Type and Size }\end{array}$ \\
\cline { 2 - 4 } & 1985 & 2000 & 2010 & $\begin{array}{c}1985-2010 \\
(\% / y r)\end{array}$ \\
\hline & & & & \\
Automokiles (106) & 122.3 & 161.5 & 184.7 & 1.66 \\
Subcompact & 32.8 & 44.6 & 59.2 & 2.39 \\
Compact & 24.3 & 32.7 & 37.8 & 1.78 \\
Midsize & 34.5 & 45.2 & 49.3 & 1.44 \\
Large & 30.7 & 39.1 & 38.4 & 0.90 \\
& & & & \\
Light trucks (10 & 23.5 & 39.6 & 44.6 & 2.60 \\
Conipact & 3.5 & 6.8 & 9.3 & 3.99 \\
Standard & 12.6 & 19.5 & 20.4 & 1.95 \\
Minivan/sm. utility & 1.7 & 5.1 & 4.4 & 3.88 \\
Standard van/utility & 5.7 & 8.2 & 7.8 & 1.26 \\
& & & & \\
Total LDVa (106) & 145.8 & 201.2 & 229.4 & 1.83 \\
& & & & \\
Autos per capita & 0.511 & 0.602 & 0.654 & 0.99 \\
Light trucks per capita & 0.098 & 0.148 & 0.158 & 1.93 \\
LDV per capita & 0.609 & 0.750 & 0.812 & 1.16 \\
Auto share of LDVs & 0.839 & 0.803 & 0.805 & -0.17 \\
\hline
\end{tabular}

aLight-duty vehicles.

Sources: 1985 data from Ref. 30, forecasts from TEEMS.

These downward trends in fuel economy among vehicles capturing a larger share of the market have led to a decline in the estimated fuel economy of the car and truck fleet in 1989, the first such decline since 1984. Oak Ridge investigators estimate that the fuel economy of the new vehicle fleet in 1989 will be only $2 \%$ better than in 1982.28

The long-term component of the equation dominates the GGTEM estimate of fuel economy in the 1990s. After a low point in 1992, the steady rise in real gasoline price (to $\$ 1.60 /$ gal in 2010) brings EPA-rated new-car fuel economy to about $42 \mathrm{mpg}$ in 2010, an average increase of $2.7 \% / \mathrm{yr}$. This gasoline-price-driven projection may be compared with the $5.3 \% / \mathrm{yr}$ increase that was achieved between 1974 and 1988 under the combined influence of higher gasoline prices, environmental regulation, and fuel efficiency standards. This fuel economy improvement is induced by post-2003 real gasoline prices higher than any previously seen in U.S. history, but still well below those in Japan, Brazil, France, Denmark, and Italy and comparable to 1987 prices in England, India, and West Germany. ${ }^{33}$ 
TABLE 2.3 Vehicle-Miles Traveled by Type and Size of Personal Vehicle, ANL-90N

\begin{tabular}{|c|c|c|c|c|}
\hline \multirow[b]{2}{*}{ Type and Size } & \multicolumn{3}{|c|}{$\begin{array}{c}\text { Travel (VMT), } \\
\text { by Year }\end{array}$} & \multirow{2}{*}{$\begin{array}{c}\text { Change, } \\
1985-2010 \\
(\% / y r)\end{array}$} \\
\hline & 1985 & 2000 & 2010 & \\
\hline Automobile $\left(10^{9}\right)$ & $1,057.8$ & $1,386.6$ & $1,570.3$ & 1.59 \\
\hline Subcompact & 292.9 & 392.6 & 514.7 & 2.28 \\
\hline Compact & 210.9 & 282.5 & 322,5 & 1.71 \\
\hline Midsize & 297.0 & 387.5 & 418.8 & 1.38 \\
\hline Large & 257.0 & 323.9 & 314.4 & 0.81 \\
\hline Light Truck $\left(10^{9}\right)$ & 209.3 & 345.4 & 384.9 & 2.47 \\
\hline Compact & 31.1 & 59.8 & 81.1 & 3.91 \\
\hline Standard & 110.3 & 167.6 & 173.6 & 1.83 \\
\hline Minivan/sm utility & 16.2 & 46.5 & 59.1 & 5.31 \\
\hline Standard van/utility & 51.7 & 71.6 & 71.1 & 1.28 \\
\hline Total LDVa $\left(10^{9}\right)$ & $1,267.0$ & $1,732.0$ & $1,955.1$ & 1.75 \\
\hline LDV VMT per capita & 5,295 & 6,455 & 6,918 & 1.08 \\
\hline LDV VMT/vehicle & 8,690 & 8,608 & 8,523 & -0.08 \\
\hline LDV VMT/household & 14,597 & 16,355 & 16,942 & 0.60 \\
\hline
\end{tabular}

a Light-duty vehicles.

Sources: 1985 data from Ref. 30, forecasts from TEEMS.

Although our model projects substantial gains in passenger-car fuel efficiency due to price changes, it is debatable whether such increases will be induced by price alone. Gasoline prices in Japan, Sweden, and the United Kingdom are from 120 to $250 \%$ higher than in the United States. However, for all four of these nations, the average fuel efficiencies of new vehicles are comparable. ${ }^{34}$ Presumably, shorter driving distances (hence, less annual travel per vehicle) tend to reduce the economic incentive for fuel efficiency relative to the United States.

The VMT-weighted fuel economy for the entire personal vehicle fleet is shown in Table 2.5. The values in the table do not include business fleets or other nonhouseholdbased vehicles, and they differ somewhat from the overall averages projected by the GGTEM model that serve as targets in the projection process. 
TABLE 2.4 Fuel Use by Type and Size of Personal Vehicle, ANL-90N

\begin{tabular}{|c|c|c|c|c|}
\hline \multirow[b]{2}{*}{ Type and Size } & \multicolumn{3}{|c|}{$\begin{array}{c}\text { Fuel Use }\left(10^{15} \mathrm{Btu}\right), \\
\text { by Year }\end{array}$} & \multirow{2}{*}{$\begin{array}{c}\text { Change, } \\
1985-2010 \\
(\% / y r)\end{array}$} \\
\hline & 1985 & 2000 & 2010 & \\
\hline Automobile & 7.396 & 8.265 & 8.085 & 0.36 \\
\hline Subcompact & 1.613 & 1.902 & 2.196 & 1.24 \\
\hline Compact & 1.373 & 1.563 & 1.569 & 0.54 \\
\hline Midsize & 2.210 & 2.447 & 2.316 & 0.18 \\
\hline Large & 2.200 & 2.354 & 2.005 & -0.37 \\
\hline Light trucks & 1.921 & 2.544 & 2.743 & 1.44 \\
\hline Compact & 0.226 & 0.383 & 0.472 & 2.99 \\
\hline Standard & 1.052 & 1.415 & 1.323 & 0.92 \\
\hline Minivan/sm. utility & 0.122 & 0.306 & 0.349 & 4.29 \\
\hline Standard van/utility & 0.521 & 0.639 & 0.573 & 0.38 \\
\hline Total & 9.317 & 10.809 & 10.828 & 0.60 \\
\hline
\end{tabular}

Sources: 1985 data from Ref. 30, forecasts from TEEMS.

TABLE 2.5 Fuel Economy of Personal

Vehicles, ANL-90N

\begin{tabular}{lccc}
\hline & \multicolumn{3}{c}{ Fuel Economy $(\mathrm{mpg})$} \\
\cline { 2 - 4 } Year & Automobile & Light Truck & Total \\
& & & \\
\hline & & & \\
1985 & 17.9 & 13.6 & 17.0 \\
1990 & 19.1 & 14.5 & 18.0 \\
1995 & 20.3 & 15.4 & 19.1 \\
2000 & 21.0 & 15.7 & 19.7 \\
2005 & 22.6 & 16.7 & 21.1 \\
2010 & 24.3 & 17.7 & 22.6 \\
& & & \\
\hline
\end{tabular}




\subsection{FLEET AUTOMOBILES}

\subsubsection{Methodology}

Fleet automobiles may be defined by either ownership (i.e., nonhousehold) or number of units owned (e.g., autos in fleets of 10 or more). Since our personal vehicle model projects household-owned vehicles, we define fleet automobiles as nonhouseholdowned. Using historical data on autos owned by either commercial establishments or government agencies, a profile of nonhousehold vehicles was constructed for 1983, the most recent year for which detailed statistics were available, and a set of ownership rates was developed for several prior years. ${ }^{19,35,37-41}$ The Commercial Fleet Survey conducted by the University of Michigan's Institute for Social Research was the major data source used to construct the fleet auto profile, portions of which are displayed in Table 2.6.35 This analysis suggested that some 8.7 million fleet automobiles were on the road in 1983 and that the number of these vehicles was growing at a rate somewhat less than that of householdowned automobiles. Both these findings differ from results reported elsewhere. ${ }^{39}$

The fleet automobile model projects light-duty fleet vehicles (automobiles and light trucks) as a function of historical trends. The numbers of commercial- and governmentowned light trucks (see below) from the ANL-90N forecast are then deducted, leaving fleet automobiles as the residual. Fleet auto activity is computed from this vehicle count and an aggregate estimate of average vehicle utilization. To account for variations in age distributions and a somewhat greater share of larger vehicles, the fuel economy of fleet automobiles is computed as a multiple of the average fuel economy of personal automobiles.

\subsubsection{Results}

Table 2.7 presents the ANL-90N projection of fleet auto stocks, VMT, fuel use, and fuel economy. Stocks grow at an annual rate of slightly more than $1.5 \%$, somewhat less than historical growth in total nonhousehold vehicles but consistent with the economic and demographic assumptions of the baseline scenario. Since fleet autos have shorter replacement cycles than automobiles in personal use, this suggests new fleet auto sales of some 3.9 million in 2000 and 4.7 million in 2010 . Policies that limit vehicle depreciation and tax employer-provided vehicles as ordinary income continue to reduce the ratio of fleet auto stocks to GNP.

\subsection{COMMERCIAL AVIATION}

Air travel dominates intercity passenger-miles traveled. Spurred by deregulation of the industry, revenue passenger-miles (RPM) flown on domestic flights rose $74 \%$ between 1975 and 1987.40 Energy consumption grew by only $32 \%$ during this period, however, 


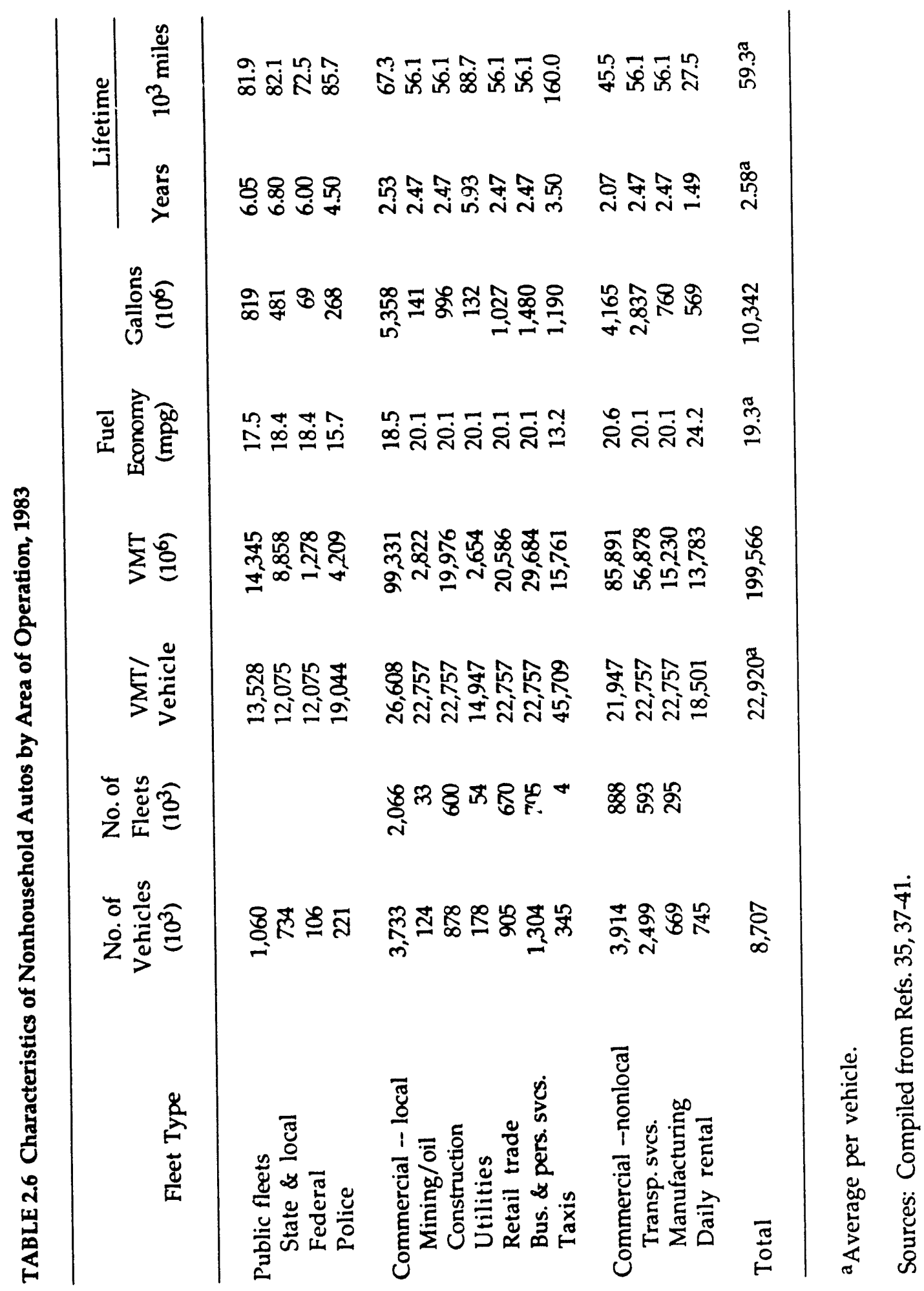


TABLE 2.7 Projected Characteristics of Fleet Automobiles, ANL-90N

\begin{tabular}{|c|c|c|c|c|c|}
\hline Projected Item & 1985 & 1990 & 1995 & 2000 & 2010 \\
\hline Vehicles $\left(10^{6}\right)$ & 8.90 & 9.16 & 9.90 & 10.82 & 12.98 \\
\hline Vehicle-miles traveled $\left(10^{9}\right)$ & 204.70 & 210.67 & 238.70 & 270.38 & 324.53 \\
\hline Energy consumption ( $\left.10^{15} \mathrm{Btu}\right)$ & 1.27 & 1.32 & 1.37 & 1.43 & 1.33 \\
\hline Fuel economy (mpg) & 20.1 & 20.1 & 21.8 & 23.7 & 30.6 \\
\hline Vehicles $/ \$ 10^{6}$ GNP & 2.02 & $1.8^{\prime}$ ? & 1.69 & 1.69 & 1.57 \\
\hline
\end{tabular}

because energy intensity (Btu/RPM) declined $24 \%$ between 1970 and 1975 and $28 \%$ between 1975 and 1985.43 In the past several years, jet fuel consumption has begun to grow rapidly. From 1977 to 1983, when the price of jet fuel was well above its post-1983 level, there was almost no change in consumption. By contrast, diesel consumption expanded more rapidly during that time than since 1983, despite the worst recession since World War II. As is the case with equations reported elsewhere, ${ }^{44}$ a rise in jet fuel price induces a decline in revenue passenger-miles (hence, jet fuel use) in our air-transport equation (Eq. 4). Furthermore, a general rise in refined-product prices produces a shift toward diesel fuel in our freight sector submodel (see Sec. 3.1 and Refs. 4, 5, and 45). Thus, in the ANL-90N projection, higher energy prices cause a return to the 1977-1983 pattern (when diesel consumption grew more rapidly than jet fuel consumption). Deregulation is not included in the equation, although it is widely recognized as a major factor behind the sharp rise in air travel demand since 1983.46-48 In essence, it is assumed that deregulation caused a onetime upward shift in demand; in the long run, however, real household income and fuel cost are the principal determinants of air travel demand.

\subsubsection{Methodology}

The TEEMS system contains a separate travel-demand model to project intercity travel by auto, air, bus, and rail modes. Inputs to this model include projections of population, employment, and economic activity for all consolidated metropolitan areas, as well as coded networks representing travel times and travel costs for each mode. The model was originally calibrated in the early 1980s with 1977 data. Since then, deregulation dramatically altered intercity air service, and resources for federally supported data collection were drastically cut. As a result, modal networks (especially travel costs) and calibration are out of date, and recalibration data are dispersed among numerous sources. Thus, the intercity travel demand model was not used in the ANL-90N forecast. Instead, air revenue passenger-miles (RPM) and energy use are directly estimated. Air RPM values are projected as a function of changes in personal income and jet fuel price. Commercial aviation energy is then computed as the product of RPM and energy intensity, an exogenous input. Intercity automobile travel is estimaied as part of the personal and fleet travel projections. 
To directly estimate air passenger travel, statistics on domestic revenue passengermiles for 1970-1988 were regressed against real disposable personal income (DPI, in billions of dollars) and two-year changes in jet fuel price (JP). The resulting equation is as follows:

$$
R P M=0.212 \mathrm{DPI}-0.12 \mathrm{JP}-262.344
$$

The model has a coefficient of determination $\left(R^{2}\right)$ of 0.985 and a Durbin-Watson statistic of 1.789 , indicating unlikely intercorrelation. Analysis indicates that $\mathrm{T}$ statistics are significant at the 0.001 level for DPI, but only at the 0.1 level for changes in jet fuel price. While other forms of the equation had superior $t$ statistics, there was significant intercorrelation between the variables. Other variables, including constant-dollar yield (revenue per passenger-mile) and jet fuel price, were also investigated. However, models containing those variables were inferior to the one presented above in either fit or predictive ability.

\subsubsection{Input Assumptions}

The continued strong growth in air travel projected under the baseline scenario provides both an incentive for airlines to purchase and an opportunity for manufacturers to produce new-generation, fuel-efficient aircraft. New aircraft now offered by manufacturers are $40-60 \%$ more energy efficient than those produced 20 years ago. Such aircraft technologies as higher bypass-ratio engines, improved compressor and turbine designs, and new propeller designs are currently in advanced stages of development. In many cases, introduction is more a matter of economic than technical feasibility. 49,50

In the baseline scenario, the fuel efficiency of commercial aircraft improves substantially. In response to rising real fuel prices, fleetwide energy intensity improves by about 1.5\%/yr between 1990 and 2010. While considerably less than Boeing's forecast of a $2 \% / y r$ gain through 2000 in conjunction with constant real fuel prices, ${ }^{46}$ this is comparable to our projection of a $1.6 \% / y r$ gain in automotive efficiency. In the near term, efficiency improvements come mainly from evolutionary changes in engines and inflight operations, increased materials substitution, and the mandated retirement of older aircraft due to noise regulations. Specific technologies include advanced electronic controls to optimize fuel burn under given flight conditions, higher pressure ratios and turbine entry temperatures, and composite structures (including metal matrix materials) to reduce weight and increase efficiency. In the intermediate and longer terms, rising real fuel prices bring further improvements in compressor and turbine efficiencies, additional materials substitution, and the development of ultra-high bypass turbofans and active controls to optimize aerodynamics.

The airline industry has an excellent record of adopting new technologies to reduce costs and improve efficiency, and most carriers are now in the process of renewing their fleets. However, aircraft manufacturers have little competition and a substintial order backlog, which is already limiting the rate at which carriers can replace aircraft. Thus, new energy-efficient technologies like the propfan (Boeing 7J7) are not being produced because safety and noise concerns dictate mounting the engine on the rear fuselage. This effectively 
limits application to aircraft no larger than 180 seats. Because the fuel-economy benefit is believed to be only $8 \%$ over the ultra-high bypass engine, which is not size limited, manufacturers are concentrating their resources on the latter technology. ${ }^{49,50}$ Therefore, high-bypass turbofans are included in the base case, while propfans are not.

Airport congestion is becoming an increasingly serious problem, not only in terms of the delays experienced by the traveling public but also because it reduces equipment utilization and fuel efficiency. Hisiorically, airport capacity addition has been the policy of cheice for combating congestion. However, this is no longer a viable alternative for most metropolitan areas. No new major airports have been built in this country since the early 1970s. A number of factors -- including the increasing scarcity (and cost) of vacant land in metropolitan areas, noise concerns, and attendant public opposition -- are responsible. Since these factors are not likely to change, little capacity addition is assumed under the baseline scenario. Some congestion relief is expected to come from improvements in air traffic control and the continued shift to larger-capacity aircraft.

The Federal Aviation Administration (FAA), the airlines, and most major airports are studying various congestion-relief measures. Generally, they rely on new technologies to more precisely control the allocation of air space, whether for safe spacing between aircraft on takeoff or landing, for lateral separation, or for the use of parallel runways. Specific capacity-increasing measures include reducing radar scan frequency (short scan) to 0.5 seconds, reducing aircraft stagger or lateral separation to 1.5 miles, reducing aircraft spacing from 4300 to 2500 feet on parallel runways, and shortening converging runway requirements. 51 Some of the technologies needed to implement these measures are part of the next-generation air-traffic-control system currently under development.

The average number of seats per aircraft rose from 111 in 1970 to 161 in 1987.43 Most of this increase came from substituting wide-bodied for narrow-bodied aircraft, a trend that is expected to continue. $46,47,52$ Load factors (i.e., the percent of seats occupied by revenue passengers) also improved over this period, from just under $50 \%$ to over $62 \%$. Although some forecasters expect load factors to reach $66-67 \%$ by $2000,44,45$ such improvements are unlikely, given the specifications in the baseline scenario (i.e., moderate fuel prices, continued increases in aircraft size, and flight delays that hamper connectivity), which are assumed to hold load factors essentially constant.

In theory, intercity-travel demand can be reduced if viable substitutes are made available to the traveling public. Videoconferencing and other forms of telecommunication are possible substitutes, particularly for business trips. However, history suggests that these technologies are more likely to supplement than replace face-to-face contact. Air travel has grown largely because deregulation caused fares to decline in real terms, and economic growth caused real incomes to rise. Neither of these trends is likely to change dramatically. While various forms of taxes and surcharges could increase the cost of providing air travel, thereby inducing travelers to substitute telecommunications, including carriers to undertake further operating improvements (e.g., higher load factors, larger capacity aircraft, etc.), or both, such changes are not included in tho baseline scenario. 
The base case also excludes all fuel-substituting aviation technologies. One possibility, a nationwide system of magnetically levitated (maglev) vehicles, ${ }^{53,54}$ ultimately could reduce jet fuel use by $0.26-0.37$ quads (one quad is $10^{15} \mathrm{Btu}$ ). ${ }^{53}$ Although such a system will require additional development before substantial introduction is possible, the first routes are already in advanced stages of planning. Construction is expected to begin soon on a short route between the Orlando, Florida, airport and Disney World; a more lengthy route, from Los Angeles to Las Vegas, could begin construction before 2000. While maglev routes could be operating in the 2000-2010 timeframe, maglev is not included in the baseline scenario because of the uncertainty of the technology itself and of the capital required to introduce it.

\subsubsection{Results}

The time advantage of air travel makes it the most attractive mode for business travel and a competitive mode for nonbusiness travel. Despite rising fuel (and ticket) costs, commercial aviation captures an increasing share of travel relative to other modes. Airline revenue passenger-miles increase at a rate of $3.6 \% / \mathrm{yr}$, while vehicle-miles of travel in private motor vehicles increase at an average rate of only $1.6 \% / \mathrm{yr}$. Since the $25 \%$ improvement in the energy efficiency of household vehicles amounts to about $1.1 \% / y r$, efficiency gains nearly keep pace with travel growth by light-duty personal vehicles (energy use grows by only $13 \%$ over the period). By contrast, growth in air travel far surpasses the $33 \%(1.6 \% / \mathrm{yr})$ improvement in commercial aircraft energy efficiency, leading to a $60 \%$ increase in jet fuel consumption.

Table 2.8 presents the key features of the air passenger forecast. Between 1990 and 2010, revenue passenger-miles nearly double, while fuel consumption rises by only $29 \%$. Because of continued improvements in the fuel efficiency of the aircraft fleet, energy intensity drops by one-third over the next 20 years. Population and income growth result in increases in a number of activity ratios. Per-capita passenger-miles rise by $72 \%$, from 1376 in 1990 to 2366 in 2010. Because of continued declines in average household size, passengermiles per household grow somewhat less rapidly, by some $62.5 \%$ over the forecast period. Passenger-miles per unit of GNP grow least rapidly, primarily because per-capita income is rising and is already captured by disposable personal income in the projection equation. (Eq. 4)

Although the TEEMS model does not project such changes to occur, it is informative to relate the implications of recent growth in jet fuel use vs. diesel fuel use. With RPM growth at the rates shown in Table 2.8 , jet fuel consumption could surpass diesel consumption by 2020. This could happen if energy prices remained low, low fares continued to increase the demand for air travel, and aircraft fuel-efficiency improvements failed to keep pace. Because diesel demand is also expected to grow substantially over the forecast period (see Sec. 4.1.1), strong growth in jet fuel demand could strain middle distillate supplies and, at least in the short run, push prices above those assumed in the baseline scenario. Strong growth could also aggravate anticipated shortfalls in 
TABLE 2.8 Key Features of the Air Passenger Forecast, ANL-90N

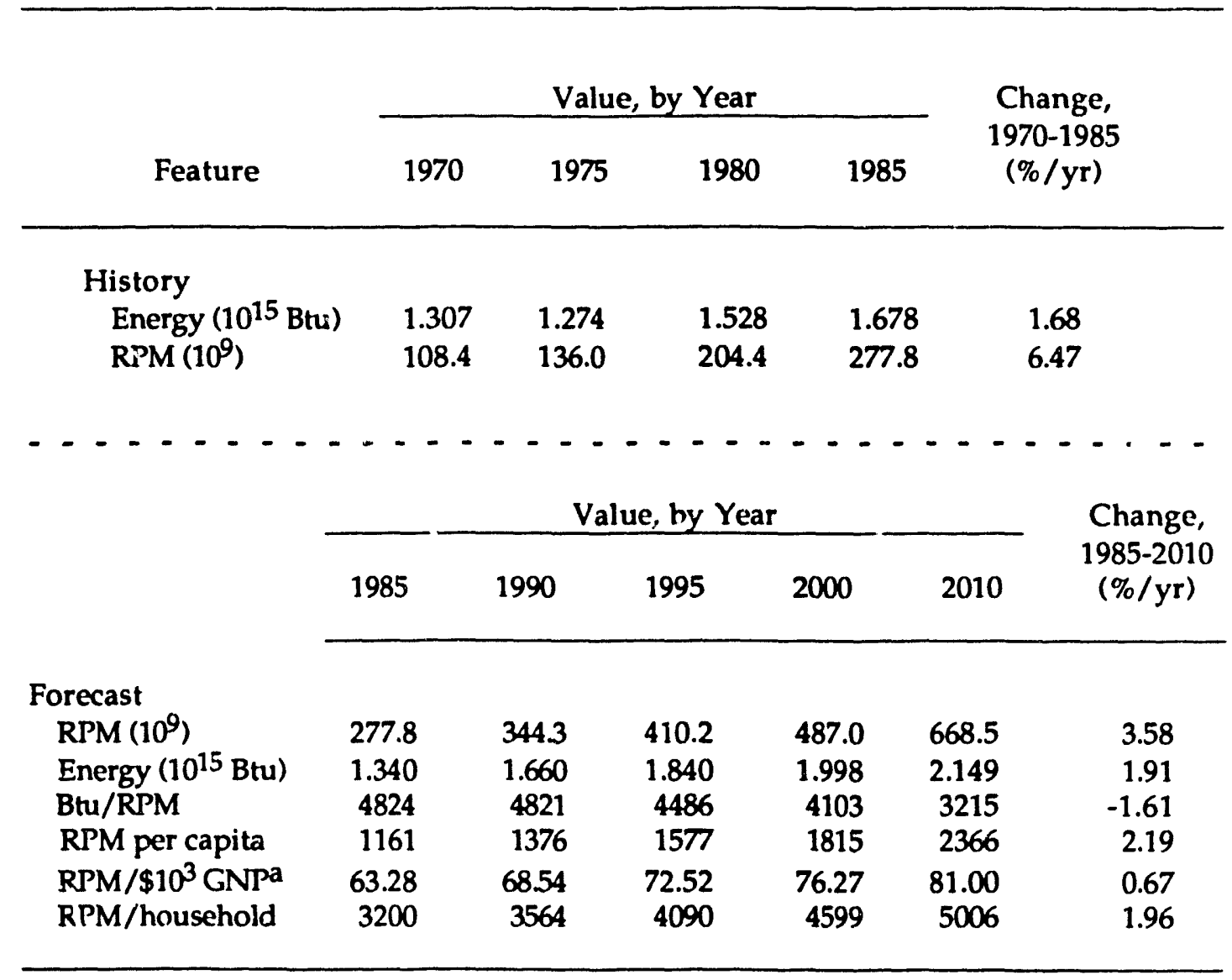

a1988 dollars.

Sources: $1970-1985$ from Refs. 40 and 41; 1990-2010 from ANL-90N.

hydrocracking capacity to produce specification kerosene-type jet fuel. The issue of refinery $\mathrm{mix}$ is beyond the scope of this analysis. However, the possibility of an imbalance in middle distillate demand and consequent refinery investment needs suggests that additional attention should be focused on improving the efficiency of the aircraft fleet and reducing airport congestion.

\subsubsection{Comparisoii with Other Current Forecasts}

Forecasts of domestic revenue passenger-miles are regularly issued by the FAA and by several aircraft manufacturers. The U.S. Department of Energy's Energy Information Administration (EIA), Data Resources, Inc., and the Gas Researci) Institute (GRI) also produce RPM forecasts when developing their projections of jet fuel demand. Table 2.9 compares the ANL-90N projections with the most recent of these RPM and jet fuel 
TABLE 2.9 Forecasts of Domestic Revenue Passenger-Miles and Jet Fuel Use, 1985-2010

\begin{tabular}{|c|c|c|c|c|c|c|c|}
\hline \multirow{2}{*}{$\begin{array}{l}\text { Variable } \\
\text { by Source }\end{array}$} & \multicolumn{6}{|c|}{ Value, by Year } & \multirow{2}{*}{$\begin{array}{c}\text { Change, } \\
1985-2010 \\
(\% / y r)\end{array}$} \\
\hline & 1985 & 1990 & 1995 & 2000 & 2005 & 2010 & \\
\hline \multicolumn{8}{|l|}{$\begin{array}{l}\text { RPM } \\
\left(10^{9}\right)\end{array}$} \\
\hline$A N L^{a}$ & 277.8 & 344.3 & 410.2 & 487.0 & 564.2 & 668.5 & 3.58 \\
\hline $\mathrm{FAA}^{\mathrm{b}}$ & 268.8 & 346.3 & 433.8 & 540.0 & & & 4.76 \\
\hline $\mathrm{ELA}^{\mathrm{c}, \mathrm{d}}$ & $505.2^{e}$ & 543.5 & 656.9 & 775.7 & 921.4 & 1101.7 & 3.17 \\
\hline GRId & $366.5^{f}$ & & 473.5 & 574.6 & 641.8 & 717.7 & 2.84 \\
\hline Bocingc & 351.1 & 469.7 & 612.4 & 775.2 & 968.9 & & 5.21 \\
\hline Greene $^{c}$ & $544.7 \mathrm{~g}$ & & 722.4 & 865.6 & 995.3 & 1125.8 & 3.52 \\
\hline \multicolumn{8}{|l|}{$\begin{array}{l}\text { Jet fuel } \\
\left(10^{15} \mathrm{Btu}\right)\end{array}$} \\
\hline $\mathrm{ANL}^{\mathrm{a}}$ & 1.340 & 1.660 & 1.840 & 1.998 & 2.015 & 2.149 & 1.91 \\
\hline $\mathrm{FAA}^{\mathrm{b}}$ & 1.337 & 1.708 & 1.938 & 2.069 & & & 2.95 \\
\hline $\mathrm{EIA}^{\mathrm{h}}$ & $2.982^{e}$ & 3.075 & 3.327 & 3.530 & 3.767 & 4.047 & 1.40 \\
\hline DRI h & & 3.127 & 3.380 & 3.523 & & 3.998 & 1.34 \\
\hline $\mathrm{GRI}^{\mathrm{C}}$ & $2.287^{f}$ & & 2.837 & 3.272 & 3.493 & 3.714 & 2.04 \\
\hline Greene ${ }^{c}$ & $2.295 \mathrm{~g}$ & & 2.795 & 3.051 & 3.254 & 3.510 & 2.04 \\
\hline \multicolumn{8}{|l|}{$\begin{array}{l}\text { Efficiency } \\
\text { (Btu/RPM) }\end{array}$} \\
\hline $\begin{array}{l}\text { ANL } \\
\text { FAA }\end{array}$ & $\begin{array}{l}4824 \\
4974\end{array}$ & $\begin{array}{l}4821 \\
4932\end{array}$ & $\begin{array}{l}4486 \\
4467\end{array}$ & $\begin{array}{l}4103 \\
3831\end{array}$ & 3571 & 3215 & $\begin{array}{l}-1.61 \\
-1.73\end{array}$ \\
\hline EIA & $5^{\prime} \not 03^{e}$ & 5658 & 5065 & 4551 & 4088 & 3673 & -1.88 \\
\hline GRI & $6240^{f}$ & & 5992 & 5694 & 5443 & 5175 & -0.78 \\
\hline Greenec & 42138 & & 3869 & 3525 & 3269 & 3118 & -1.42 \\
\hline
\end{tabular}

ascheduled and unscheduled domestic traffic.

${ }^{b}$ Scheduled domestic traffic (includes regional/commuter carriers).

'Scheduled and unscheduled traffic of U.S. carricrs (includes international operations).

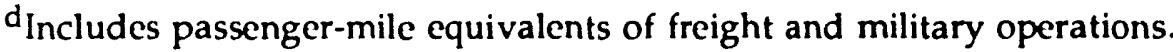

e 1988 estimate. 
TABLE 29 (Cont'd)

f1986 estimate.

g1989 estimate.

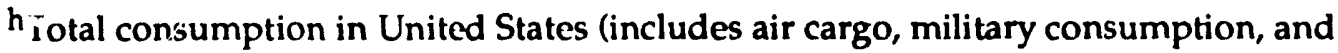
fuel purchased by foreign flag carriers).

Sources: Refs. 46, 47, 5?, 55-57.

forecasts, as well as with a recent forecast developed by Greene. ${ }^{52}$ Despite major differences in coverage (see table footnotes), all forecasts concur in anticipating relatively strong RPM growth. The GRI and EIA foresee roughly comparable 53-57\% growth through the year 2000. On the other hand, ANL, Greene, and FAA are somewhat more optimistic, forecasting 75\%, 60\% (from a 1989 base), and 100\% growth, respectively, through that year. Boeing is thit most optimistic, predicting $121 \%$ growth through 2000 and annual increases of over $5.2 \%$ through 2005 .

The EIA and ANL foresee energy intensity dropping by approximately a third between 1985 and 2010, while the FAA predicts a comparable rate of decline through 2000. Greene expects a relatively similar improvement, 26\% between 1989 and 2010. The GRI expects much less improvement, about $9 \%$ by 2000 and $17 \%$ by 2010 . These anticipated improvements in aircraft energy intensity restrain growth in jet fuel demand to the relatively modest rates shown in Table 2.9 . 


\section{PROJECTION METHODOLOGY AND RESULTS: FREIGHT MODES}

Within the Transportation Energy and Emissions Modeling System (TEEMS), a freight sector model estimates future-year activity (ton-miles or vehicle-miles) and energy consumption by mode. Indexes of sectoral output are supplied by a macroeconomic model. A mode choice model then computes ton-miles traveled by truck, rail, water, air, and pipeline for 24 commodity sectors based on commodity characteristics, changes in fuel price, energy intensities, and modal operating characteristics. An accounting submodel uses modal energy intensities, load factors, and size/subactivity allocation factors to compute activity and energy consumption by fuel type for each freight mode. Finally, an emission module estimates emissions from the activity and energy-use projections. Emissions of hydrocarbons, nitrogen oxides, carbon monoxide, and carbon dioxide can be estimated. These are reported elsewhere for similar economic, demographic, and energy price scenarios. 58,59

\subsection{METHODOLOGY}

The freight-sector model projects modal activity and energy use to move goods and provide services. The model has a mode-choice component and an accounting component. The mode choice component uses commodity and modal attributes to determine mode choice. Once shifts between modes are determined, an accounting procedure is applied to compute activity and fuel consumption. Five modes are considered: truck, rail, marine, air, and pipeline.

The mode-choice component simulates decision making by a shipper who selects a freight mode to maximize his utility. 60,61 The utility function includes shipment attributes, (e.g., size and distance-of-haul) and modal attributes, such as shipping rate, travel time, reliability, probability of damage, various cost components coritributing to the rate, and their relative share of operating cost. Shipping rates and shipment size are commodity dependent; probability of damage is both commodity and mode dependent; other attributes are mode specific. Attributes tenc' to be interrelated and to vary within a commodity/mode combination. To account for this : ariation, the model samples a prescribed number of shippers for each commodity and estimates mode choice by applying a multinomial jogit equation. A Monte Carlo simulation technique is sued in sampling.

The accounting component applies commodity-sector growth rates, commoditydependent modal energy intensities, and a set of modal activity rates to base-year ton-miles traveled (TMT) to estimate modal energy requirements and activity shares. Power unit requirements are projected where applicable. A macroeconomic model of the U.S. economy provides commodity growth rates that are consistent with other aspects of the baseline scenario. Technological improvements in each freight mode, both in power units and operating efficiencies, are identified and their impacts quantified in terms of energy intensity and/or fuel economy. 
For trucks, ton-miles are converted to vehicle-miles by application of commodityspecific load factors. These factors represent historical relationships and observed values and reflect anticipated changes in packaging, truck configuration, and load-limit regulations. Vehicle-miles are then assigned to truck size groups based on commodityspecific allocation factors. Within TEEMS, commercial truck activity and energy use are projected for four truck sizes and two fuel types. Size groups are defined by average laden weight. This analysis is focused on classes 3 through 8 , which are commonly termed heavy trucks. Size classes are:

$\begin{array}{ll}\text { Light } & \leq 10,000 \mathrm{lb} \text { (classes 1-2) } \\ \text { Medium } & 10,001-19,500 \mathrm{lb} \text { (classes 3-5) } \\ \text { Light heavy } & 19,501-26,000 \mathrm{lb} \text { (class 6) } \\ \text { Heavy heavy } & >26,000 \mathrm{lb} \text { (classes 7-8) }\end{array}$

Vehicle-miles are also split by fuel type within each size group. For the baseline scenario, fuel types are limited to gasoline and diesel oil. Energy requirements are then computed using fuel economies provided to the model. Truck stocks within each size and fuel combination are computed on the basis of historical and projected vehicle-utilization rates.

For rail, marine, and air modes, ton-miles are used to compute energy demand by commodity sector. Base-year commodity-specific energy intensities are revised to reflect the technological and operational improvements of the baseline scenario. For rail, energy demand is split between linehaul and switching operations. Marine and air freight energy demands are computed similarly. Domestic marine ton-miles are split by area of operation, and consumption of diesel and residual oil is computed for each area. Three areas of operation are considered: inland waterways, Great Lakes, and coastal. Likewise, air tonmiles are split between belly freight and all-cargo aircraft. Energy consumption is then computed using commodity-specific energy intensities, which are revised to account for technological improvements.

Pipelines are treated somewhat more generally. Because of differences in energy sources and commodities carried, petroleum and natural gas pipelines are treated separately. For natural gas, pipelines are treated as captive modes. Historical mode shares by marine, truck, and pipeline are used to allocate crude-oil and petroleum-product shipments, and commodity-specific energy intensities are used to compute energy consumption.

\subsection{TRUCKS}

Of all freight-carrying modes, commercial trucks consume the most energy, followed by pipeline, rail, and marine modes in descending order of energy consumption. (However, if fuel bunkered by foreign vessels is included, marine vessels consume more energy than either railroads or pipelines. Nonetheless, the amount of domestic fuel purchased by foreign vessels [like foreign aircraft] depends on relative prices and availability, both of 
which are beyond the scope of this analysis. Thus, ANL-90N excludes domestic fuel purchased by foreign vessels.)

In 1985 , commercial trucks accounted for $76 \%$ of the energy consumed by freight modes. Truck energy consumption has increased since 1975, while rail, marine, and pipeline consumption has declined. Commercial trucks include light-duty trucks operated by business or government and heavy-duty trucks. Light trucks are subject to Corporate Average Fuel Economy (CAFE) standards, but heavy trucks are not. Despite CAFE standards, however, the fuel used by light trucks operated by construction firms, utilities, and in other service sectors has consistently increased.

Table 3.1 presents statistics on heavy trucks from the 1982 Truck Inventory and Use Survey. 62 Nearly $21 \%$ of these trucks are owned by common carriers, owner-operators, and truck rental firms. In 1983, these trucks accounted for $40 \%$ of the vehicle-miles traveled (VMT) and $43 \%$ of the fuel consumed by heavy trucks.

The use of commercial trucks is dependent on type of product carried, size class, and operator type. The importance of operator type (e.g., private, common carrier) has been reduced considerably since deregulation of the trucking industry, and the distinction is not considered in the modelling process (i.e., TEEMS does not categorize commercial trucks by operator type). However, "for-hire" trucks continue to carry a disproportionate share of truck tonnage and to be driven longer distances than private trucks. In 1982, the "for-hire" segment accounted for about $7 \%$ of all commercial trucks and $18.5 \%$ of commercial truck VMT.

Ultimately, the demand for freight transport is driven by demand for the products or commodities to be transported. Some 22 products are identified in the 1982 Truck Inventory and Use Survey. For each vehicle in their fleet, vehicle owners were asked to supply average truck load (i.e., average operating weight less tare weight), annual VMT, and the share of VMT represented by each principal product. These shares and average loads were used to disaggregate total vehicle-miles and ton-miles to each commodity sector. Table 3.2 summarizes the results of this process -- the numbers of trucks used to haul various products and the extent of their use in terms of vehicle-miles and ton-miles. Craftsman's equipment, farm products, building materials, processed food, and mixed cargo are the biggest users of commercial trucks. These same five product categories also account for the most VMT, but in somewhat different order. Mixed cargo, processed food, farm products, building materials, and petroleum are the top five categories in terms of tonmiles. Since higher-density commodities tend to have higher average loads (i.e., TMT/VMT), as well as shorter lengths-of-haul, many such commodities account for far more ton-miles than vehicle-miles.

Table 3.3 shows how trucks of different size classes are normally used to carry various products. It also shows the dependence of some sectors on truck transport. This dependence may be due to the dispersed distribution of the product (e.g., farm products, live animals), the remote and shifting nature of the product itself (e.g., forest products, mining), 
TABLE 3.1 Characteristics of the Heavy-Duty Truck Inventory, 1982

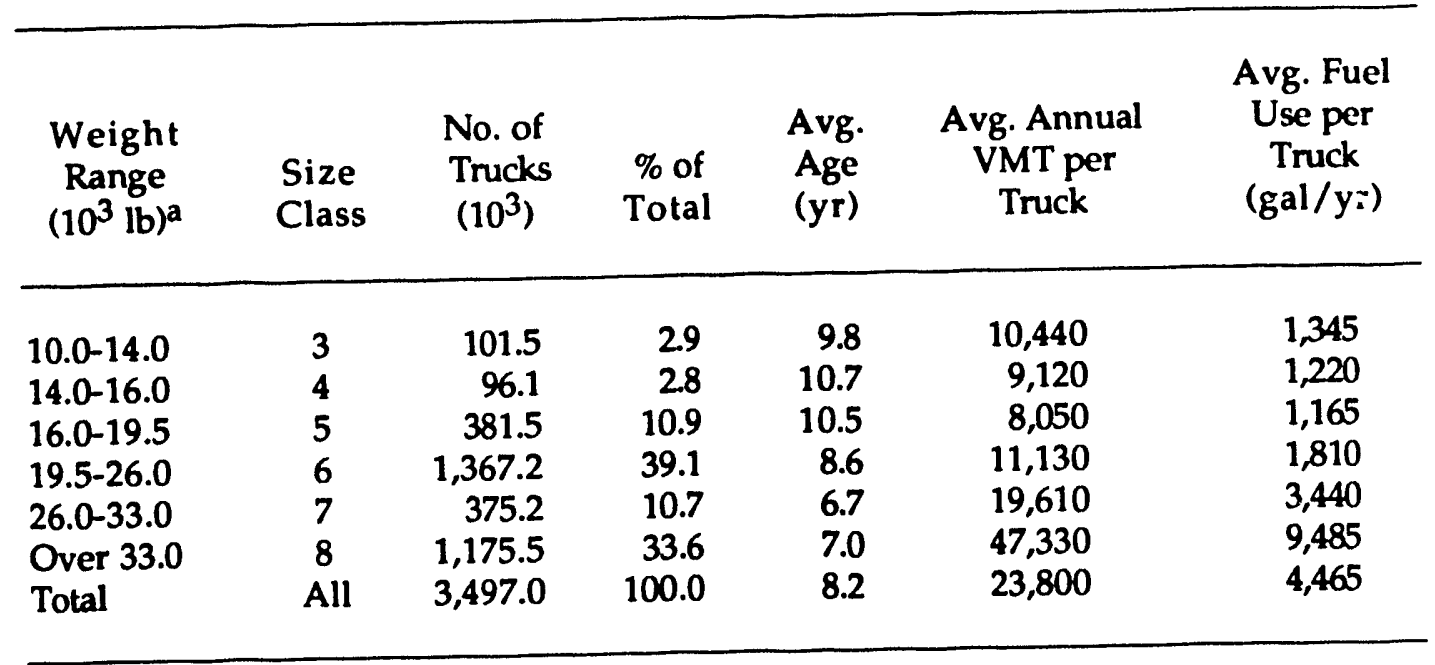

aManufacturer's gross vehicle weight rating. Within TEEMS, heavy trucks are classified as medium $(10,000-19,500 \mathrm{lb})$, light-heavy $(19,500-26,000 \mathrm{lb})$, or heavyheavy $(>26,000 \mathrm{lb})$.

Source: Ref. 62.

or the distribution system (e.g., petroleum, processed foods, building materials). The weight categories corresponding to these size classes were discussed above. Four product groups -craftsman's equipment, farm products, live animals, and building materials -- account for a majority of load-carrying light and medium trucks. This trend of five sectors accounting for more than half the vehicles in a size class applies to light-heavy and heavy-heavy trucks as well. The category of "mixed cargo" refers to trucks contracted to carry a variety of products.

Table 3.4 shows the inventory of commercial trucks and their use by major category. Again, only dedicated vehicles are included. Major use can include groups of principal products (e.g., manufacturing, wholesale trade) or uses that do not involve loads of cargo (e.g., personal services, craftsman's equipment). Trucks that typically do not carry any load (based on owner responses) are included, as are trucks used to carry goods on contract (shown as "for-hire"). The table reveals that agriculture, contract/construction, personal services, and retail and wholesale trade account for nearly $80 \%$ of all trucks. In terms of VMT, a slightly different and even more concentrated picture emerges, because contract/construction, agriculture, for-hire, wholesale trade, and personal services account for nearly $75 \%$ of all travel. The "for-hire" category accounts for nearly half of all ton-miles and has the highest vehicle utilization. Since the preponderance of trucks and VMT in certain use sectors is expected to continue, the truck modeling framework is designed to preserve sector-specific differences while permitting technological improvements to be introduced into the vehicle fleet. Section 3.2.1 discussed technological improvements. 


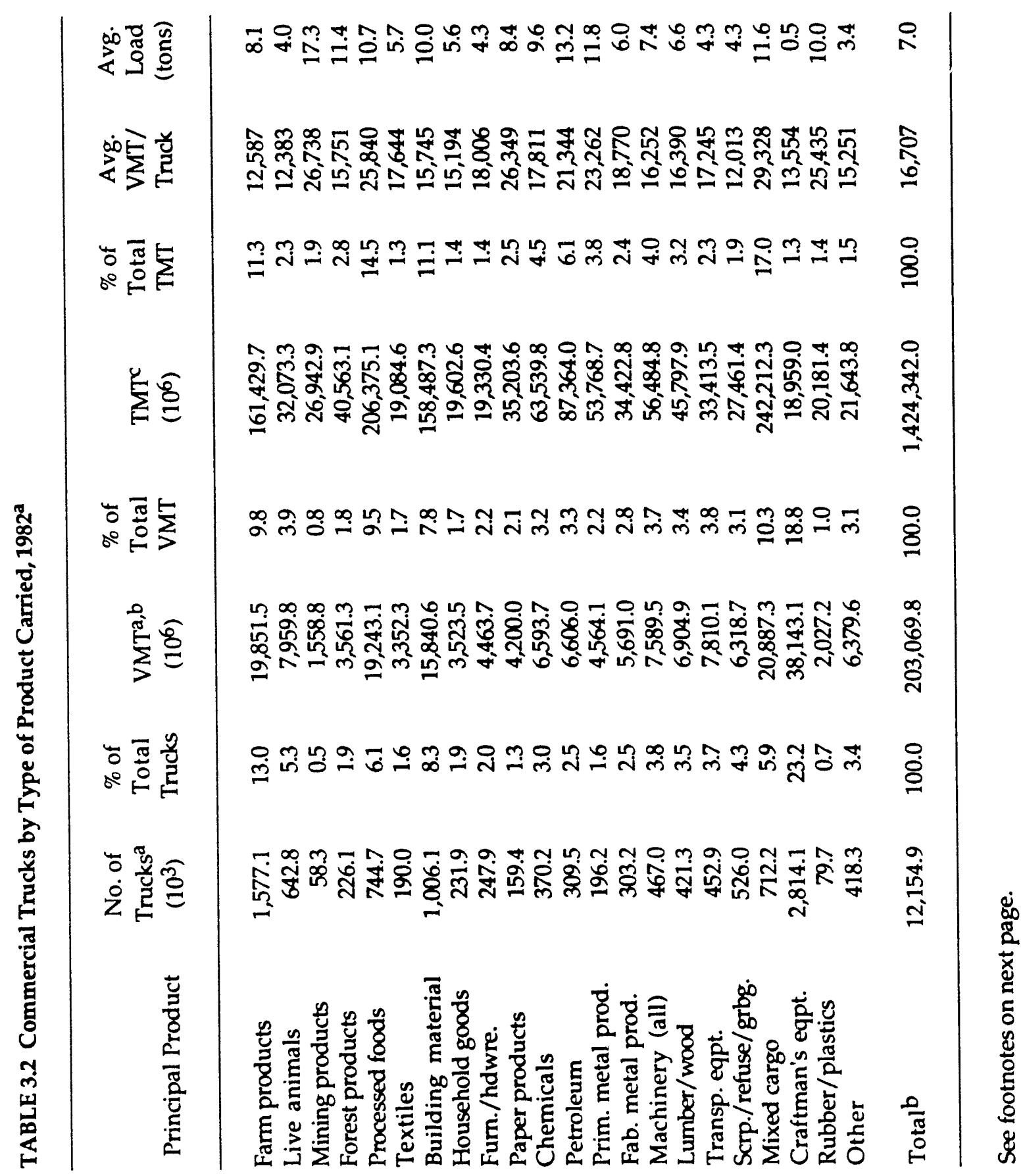




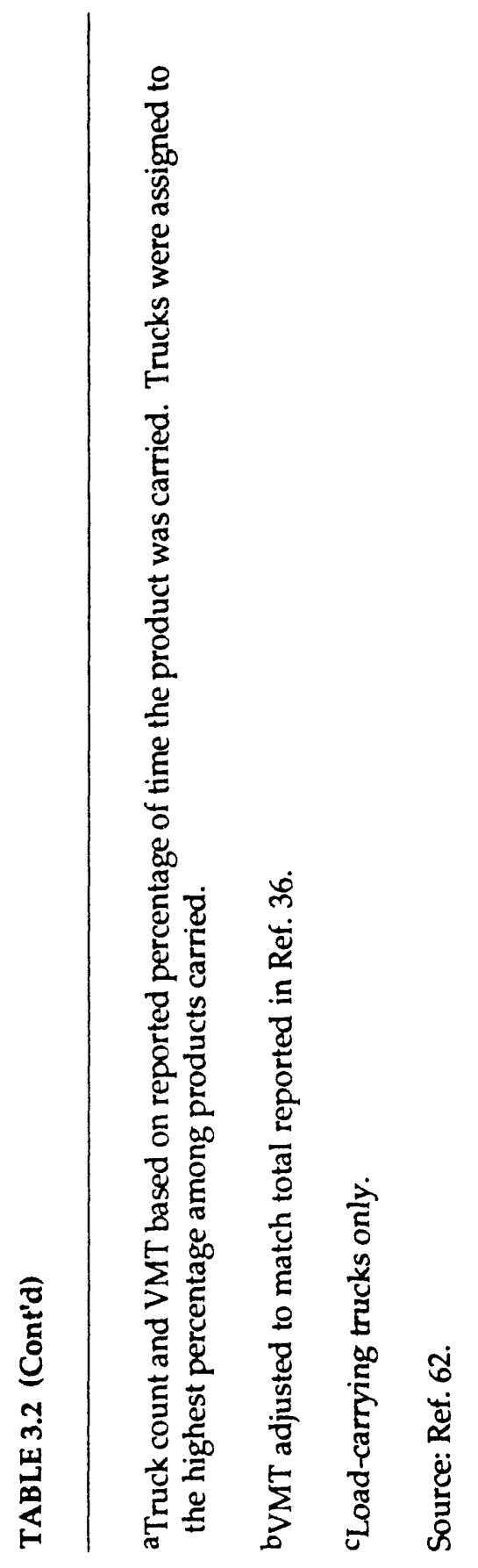


TABLE 3.3 Commercial Trucks by Size Class for Principal Product Categories, 1982 $^{\mathrm{a}}$

\begin{tabular}{|c|c|c|c|c|c|c|c|c|}
\hline Principal Product & $\begin{array}{c}\text { Light } \\
\text { Trucks } \\
\left(10^{3}\right)\end{array}$ & $\begin{array}{l}\% \text { of } \\
\text { Total }\end{array}$ & $\begin{array}{c}\text { Medium } \\
\text { Trucks } \\
\left(10^{3}\right)\end{array}$ & $\begin{array}{l}\% \text { of } \\
\text { Total }\end{array}$ & $\begin{array}{c}\text { Lt.- } \\
\text { Heavy } \\
\text { Trucks } \\
\left(10^{3}\right)\end{array}$ & $\begin{array}{l}\% \text { of } \\
\text { Total }\end{array}$ & $\begin{array}{c}\text { Hvy.- } \\
\text { Hvy. } \\
\text { Trucks } \\
\left(10^{3}\right)\end{array}$ & $\begin{array}{c}\% \text { of } \\
\text { Total }\end{array}$ \\
\hline Farm products & 834.8 & 52.9 & 187.7 & 11.9 & 371.5 & 23.6 & 183.0 & 11.6 \\
\hline Live animals & 511.3 & 79.5 & 38.5 & 6.0 & 63.9 & 9.9 & 29.1 & 4.5 \\
\hline Mining products & 19.4 & 33.3 & 1.3 & 2.2 & 6.0 & 10.3 & 31.6 & 54.2 \\
\hline Forest products & 136.3 & 60.3 & 16.0 & 7.1 & 31.1 & 13.8 & 42.8 & 18.9 \\
\hline Processed food & 367.9 & 49.4 & 31.1 & 4.2 & 147.8 & 19.8 & 197.9 & 26.6 \\
\hline Textiles & 149.9 & 78.9 & 5.8 & 3.1 & 15.5 & 8.2 & 18.9 & 9.9 \\
\hline Building mtls. & 509.9 & 50.7 & 55.2 & 5.5 & 166.4 & 16.5 & 274.6 & 27.3 \\
\hline Household goods & 123.2 & 53.1 & 23.4 & 10.1 & 53.4 & 23.0 & 31.9 & 13.8 \\
\hline Furn./hardware & 197.8 & 79.8 & 7.9 & 3.2 & 21.4 & 8.6 & 20.8 & 8.4 \\
\hline Chemicals & 232.0 & 62.7 & 15.6 & 4.2 & 57.6 & 15.6 & 65.0 & 17.6 \\
\hline Petroleum & 115.7 & 37.4 & 16.8 & 5.4 & 75.1 & 24.3 & 102.0 & 32.9 \\
\hline Prim. metal prod. & 122.7 & 62.6 & 5.8 & 3.0 & 16.8 & 8.6 & 50.9 & 25.9 \\
\hline Fab. metal prod. & 220.7 & 72.8 & 10.4 & 3.4 & 33.5 & 11.0 & 38.6 & 12.7 \\
\hline Machinery (all) & 294.3 & 63.0 & 14.4 & 3.1 & 64.0 & 13.7 & 94.4 & 20.2 \\
\hline Lumber/wood & 308.1 & 73.1 & 18.2 & 4.3 & 52.4 & 12.4 & 42.7 & 10.1 \\
\hline Transp. eqpt. & 354.0 & 78.2 & 16.9 & 3.7 & 32.2 & 7.1 & 49.9 & 11.0 \\
\hline Scrp./refuse/grbg. & 346.2 & 65.8 & 32.5 & 6.2 & 71.1 & 13.5 & 76.3 & 14.5 \\
\hline Mixed cargo & 379.7 & 53.3 & 37.7 & 5.3 & 67.2 & 9.4 & 227.6 & 32.0 \\
\hline Craftman's eqpt. & 2611.8 & 92.8 & 49.5 & 1.8 & 109.5 & 3.9 & 43.3 & 1.5 \\
\hline Rubber/plastics & 47.2 & 59.2 & 3.2 & 4.0 & 9.7 & 12.2 & 19.6 & 24.6 \\
\hline Other & 345.4 & 82.6 & 11.6 & 2.8 & 32.7 & 7.8 & 28.7 & 6.9 \\
\hline Total trucks ${ }^{b}$ & 8332.5 & 78.8 & 604.3 & 4.8 & 1518.1 & 12.0 & 2202.6 & 17.4 \\
\hline Diesels & 120.5 & 1.4 & 13.3 & 2.2 & 93.5 & 6.2 & 1570.4 & 71.3 \\
\hline
\end{tabular}

aTrucks that carry multiple products are allocated fractionally (i.e., based on the share of travel represented by each product category).

bLoad-carrying trucks only (12.66 million total vehicles).

Source: Ref. 62. 


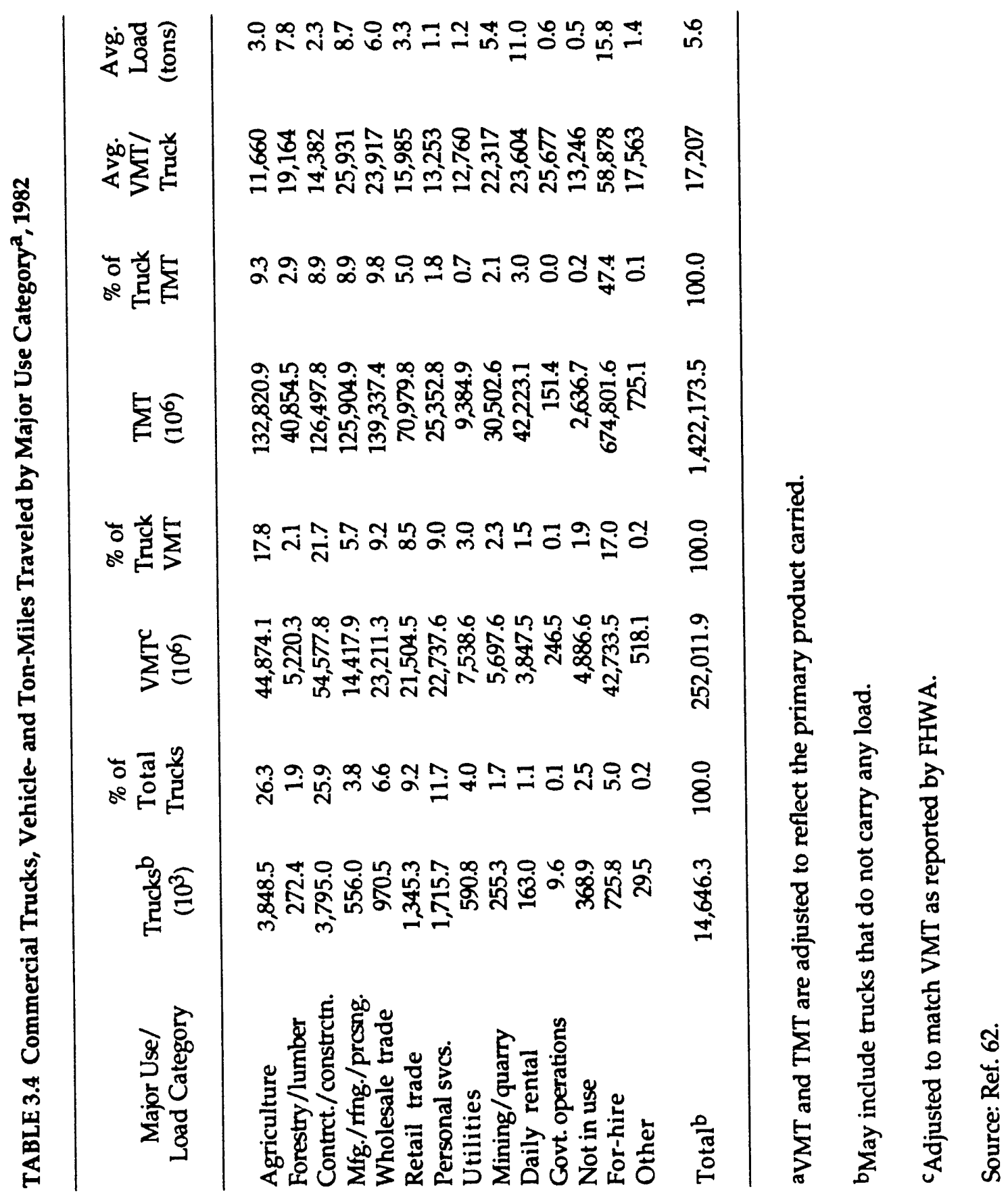




\subsubsection{Input Assumptions}

Our projections of efficiency improvements through implementation of off-theshelf technologies are less optimistic for heavy trucks than for passenger cars. Historically, heavy-truck fuel economy improved by less than $0.5 \%$ per year $(0.2 \%$ for single-unit and $0.5 \%$ for combination trucks) between 1970 and 1987.43 Fuel economy increased in the 1970 s but declined somewhat in the 1980s. Many factors have contributed to this situation, including inefficient fleet management; low load factors (including an excess of empty backhauls); poor driver training; increased urban congestion; higher speed limits on rural interstate highways; shifts within the stock of heavy trucks toward larger, less fuel-efficient vehicles; disproportionate growth in travel by these larger vehicles; and slow turnover of older, less fuel-efficient rolling stock.

Unlike the situation with passenger cars (passenger and freight load is a relatively small percentage of gross operating weight), heavy trucks can accommodate loads that are large relative to the gross weight of the vehicle, and reductions in tare weight are more likely to permit additional loading than to improve fuel economy. Thus, while weight reduction still offers substantial opportunity for improving the fuel economy of light-duty vehicles, it is not as promising for heavy trucks. Rather, the fuel efficiency of heavy trucks is expected to improve primarily from increased use of already widely accepted fuel-conservation measures, such as aerodynamic devices, radial tires, engine speed governors, fan clutches, improved axle or drivetrain ratios, diesel engines, and engines and transmissions with electronic controls. Penetration of the less costly of these measures -aerodynamic devices, radial tires, speed governors, fan clutches, high torque-rise/low-rpm engines -- was first spurred by sudden increases in the price of fuel during the 1970s and has continued with diesel fuel and road use tax increases in the 1980s. The Truck Inventory and Use Survey (TIUS) reports that radial tires were the most popular fuel-saving measure used in 1982, followed by road-speed governors. ${ }^{62}$ In 1989, radials represented $72 \%$ of the original equipment tires and $62 \%$ of the replacement tires produced for heavy trucks. ${ }^{63}$

In addition to fuel-saving measures incorporating conventional technologies, a number of new technologies have recently been developed or are expected to become commercially available in the next 20 years. These include (1) advanced aerodynamic devices to further reduce drag; (2) improved tires and lubricants; (3) improved transmissions (including use of electronic controls and improved axle or drive ratios); (4) improved engines (including specialization, electronic controls, and turbocompounding); and (5) fuel switching (increased use of diesel fuel). Each of these areas is briefly discussed below.

Aerodynamics: The American Trucking Association foresees dramatic improvements in aerodynamics through the use of integrated tractor-trailer designs with rounded cab top and nose sections, tractor/trailer gap seals, side skirts, and boattailed trailers. Already feasible, these "practical integrated designs" could improve the fuel economy of heavy-heavy trucks by $25 \%$ over conventional, nonintegrated designs with cabmounted air deflectors. 64 As fuel prices rise, advanced aerodynamic designs are likely to become commonplace. While further improvements to these integrated designs are 
possible, they may not be practical. For example, trailers would have to be redesigned, surface imperfections (i.e., dirt, dents, etc.) could not be tolerated, and trailer interchangeability might be reduced.

Improved Tires and Lubricants: Lower-friction tires and lubricants could improve on-road fuel economy by approximately $5 \%$. Specific tire technologies include low-profile (smaller diameter) tires for cube-sensitive operations (i.e., light-weight, low-density cargo) and wide-base (super) singles in place of duals for weight-sensitive over-the-road operations. Manufacturers foresee growth in both these technologies, as well as increased use of new tread compounds, design patterns, and specialization in tire design (e.g., tires designed not only for specific types of powertrains, but also tailored to specific types of freight, loadings, haul routes, interline requirements). 60 Even more than their fuel economy benefit (generally estimated at only 1-3\%), synthetic lubricants offer the benefit of reduced maintenance and extended engine life. 65

Improved Transmissions: Electronic transmission and engine controls are offered in new trucks. Although manufacturer estimates vary, electronic transmission controls may be expected to yield a fuel economy improvement of about 4\%; electronic engine controls could improve fuel economy by another $4 \%$. The speed with which these technologies penetrate the truck fleet depends on economic conditions. Sales of new trucks in classes 3 through 5 have been depressed (5,000-10,000/year) since 1980. Sales of new class 7 and 8 trucks dropped during 1980-1984 but have been on the rise since then. At the present rate, it would take 12 to 16 years for these new engine and transmission technologies to be installed in $80 \%$ of the heavy trucks on the road.

Improved Engines: Better matching of truck specifications to intended missions has been increasing the specialization of the truck fleet and improving fuel economy. This trend is expected to continue. New engine technologies such as low-heat-rejection diesels and gas turbines require structural ceramics and/or heat-insulating composites that cannot yet be economically mass-produced. These engines are not expected to be introduced before 2005 or to reach respectable market penetration levels for another 10-15 years beyond then. ${ }^{66}$ In the baseline scenario, their combined penetration is less than $1 \%$ of the heavy-heavy truck fleet in the year 2010. Turbocompound engines are already technically, but not yet economically, feasible. Fuel-efficiency improvements of 5-7\% have been documented at steady speeds. 67,68 However, because of the higher initial cost of these engines, manufacturers have chosen to defer market introduction until fuel savings permit the twoyear payback that is characteristic of this market. At base-case prices, penetration is slow but steady, reaching $10 \%$ of the fleet by 2010 .

Fuel Switching: The use of diesel fuel is increasing among heavy trucks. According to the Truck Inventory and Use Survey, $29 \%$ of all heavy trucks (classes 3-8) used diesel fuel in 1977; this rose to $38 \%$ in 1982 and $49 \%$ in $1987.62,69,70$ Diesel fuel provides a roughly $12 \%$ fuel economy improvement in trucks of comparable size, load, and duty cycle. However, since most larger trucks are already diesel fueled and are driven relatively more miles (the $38 \%$ of diesel trucks accounted for $71 \%$ of heavy-truck VMT in 1982), the opportunity for 
additional fuel switching may be limited. Other alternative fuels, primarily compressed natural gas and methanol, are not included in the baseline scenario.

Table 3.5 summarizes the market penetration and fuel efficiency benefit of specific truck technologies and other operating improvements assumed under the baseline scenario. Fuel substitution (i.e., the shift from gasoline to diesel engines) is shown in Table 3.6 by truck size class.

\subsubsection{Results}

Recent trends in heavy-truck energy consumption and VMT are shown in Table 3.7. The heavy-truck share of total transportation energy increased from $9.8 \%$ in 1970 to $14.9 \%$ in 1985.43 Energy consumption increased by $94.7 \%$ between 1970 and 1985 . In contrast, automobile energy consumption increased from 1970 to 1978 and then declined, cesulting in an overall increase of only $1.7 \%$ between 1970 and 1985 . Combined auto and light-truck energy consumption increased $22.2 \%$ during the same period. The rate of growth in heavy-truck VMT was $104.8 \%$ between 1970 and 1985 , compared with a $57.1 \%$ increase in combined automobile and light-truck VMT.

TABLE 3.5 Truck Technology and Operating Improvements

\begin{tabular}{|c|c|c|c|c|}
\hline \multirow[b]{2}{*}{$\begin{array}{l}\text { Technology or Operating } \\
\text { Improvements }\end{array}$} & \multirow[b]{2}{*}{$\begin{array}{l}\text { Efficiency } \\
\text { Gain }(\%)^{b}\end{array}$} & \multicolumn{3}{|c|}{$\begin{array}{c}\text { Penetration of Heavy- } \\
\text { Heavy Trucks (\%) }\end{array}$} \\
\hline & & 1990 & 2000 & 2010 \\
\hline Advanced drag reduction & 25 & 1 & 10 & 45 \\
\hline Improved tires \& lubricants & 5 & 1 & 50 & 80 \\
\hline Electronic transmission controls & 4 & 5 & 30 & 75 \\
\hline Electronic engine controls & 4 & 5 & 30 & 70 \\
\hline Turbocompound diesel engine & 5 & 0 & 1 & 10 \\
\hline Increased load factors (TMT/VMT) & $10-14^{\mathrm{C}}$ & d & d & $\mathrm{d}$ \\
\hline
\end{tabular}

a Low-heat-rejection diesels and turbine engines are not included in the baseline scenario. All improvements listed could be made to a single base vehicle.

b On-road improvement in mpg.

CImprovement in Btu/TMT.

d Commodity-sector dependent. 
TABLE 3.6 Diesel Shares by Truck Size Class, 1985-2010

\begin{tabular}{|c|c|c|c|c|c|}
\hline \multirow[b]{2}{*}{ Size Class } & \multicolumn{5}{|c|}{ Percentage of Vehicles in Use, by Year } \\
\hline & 1985 & 1990 & 1995 & 2000 & 2010 \\
\hline Light & 1.5 & 1.5 & 1.8 & 2.2 & 3.0 \\
\hline Medium & 2.0 & 2.9 & 4.1 & 5.8 & 10.0 \\
\hline Light-heavy & 5.8 & 7.5 & 10.0 & 13.3 & 21.1 \\
\hline Heavy-heavy & 74.0 & 76.8 & 80.0 & 85.0 & 95.0 \\
\hline
\end{tabular}

Projections of commercial truck VMT and fuel use under $t$ l e baseline scenario are also shown in Table 3.7. The base case assumes siow, but steady, economic growth and petroleum prices that are relatively high but within the range of recent history. (See Sec. 1.3 for a detailed description of the scenario.) Consistent with these economic and technological assumpticiss, ANL-90N projects strong increases in commercial truck VMT (61.1\% between 1985 and 2010) and on!y nodest increases in commercial truck fuel economy $(0.5 \%$ per yr over this timeframe). As a result of these trends, as well as some switching from gasoline to diesel fuel, diesel consumption by commercial trucks rises steadily throughout the projection period, although at a substantially slower rate $(2.5 \% / \mathrm{yr}$ from 1995 to $20 \mathrm{i} 0$ ) than in recent years. Thus, for both light and heavy-duty vehicles, the rate of growth in fuel use is reduced considerably in the 1985-2010 period, as compared with the past five years. The VMT growth rates are also less than in the recent past, primarily because of slower growth in the industrial sectors responsible for trucking demand, improved management practices that increase average loads (i.e., TMT/VMT), and relatively high diesel fuel prices. Between 1990 and 2010, diesel use by commercial trucks grows by 2.1) quads, compared with a modest 0.3 -quad increase in gasoline use.

\subsection{RAIL}

In 1985, railroads accounted for $2.5 \%$ of the energy consumed in transportation. ${ }^{43}$ Table 3.8 shows trends in rail energy consumption and intensity, in terms of Btu per tonmile-traveled (Btu/TMT). Rail energy intensity was relatively stable before 1975 . Since then, a series of events -- including the energy price shocks of 1973-1974 and 1979, increased intermodal competition spurred by deregulation, labor renegotiations (permitting, among other things, smaller crews and the elimination of cabooses on intermodal runs), locomotive replacement, and a spate of merger's and acquisitions -- have improved rail productivity and energy intensity. The energy intensity of Class 1 railroads improved by $28.6 \%$ between 1975 and 1985 . Because ton-miles rose only $10 \%$ over this period, rail energy use declined by $16 \%$. 
TABLE 3.7 Commercial Truck VMT and Energy Use by Size Class, 1970-2010

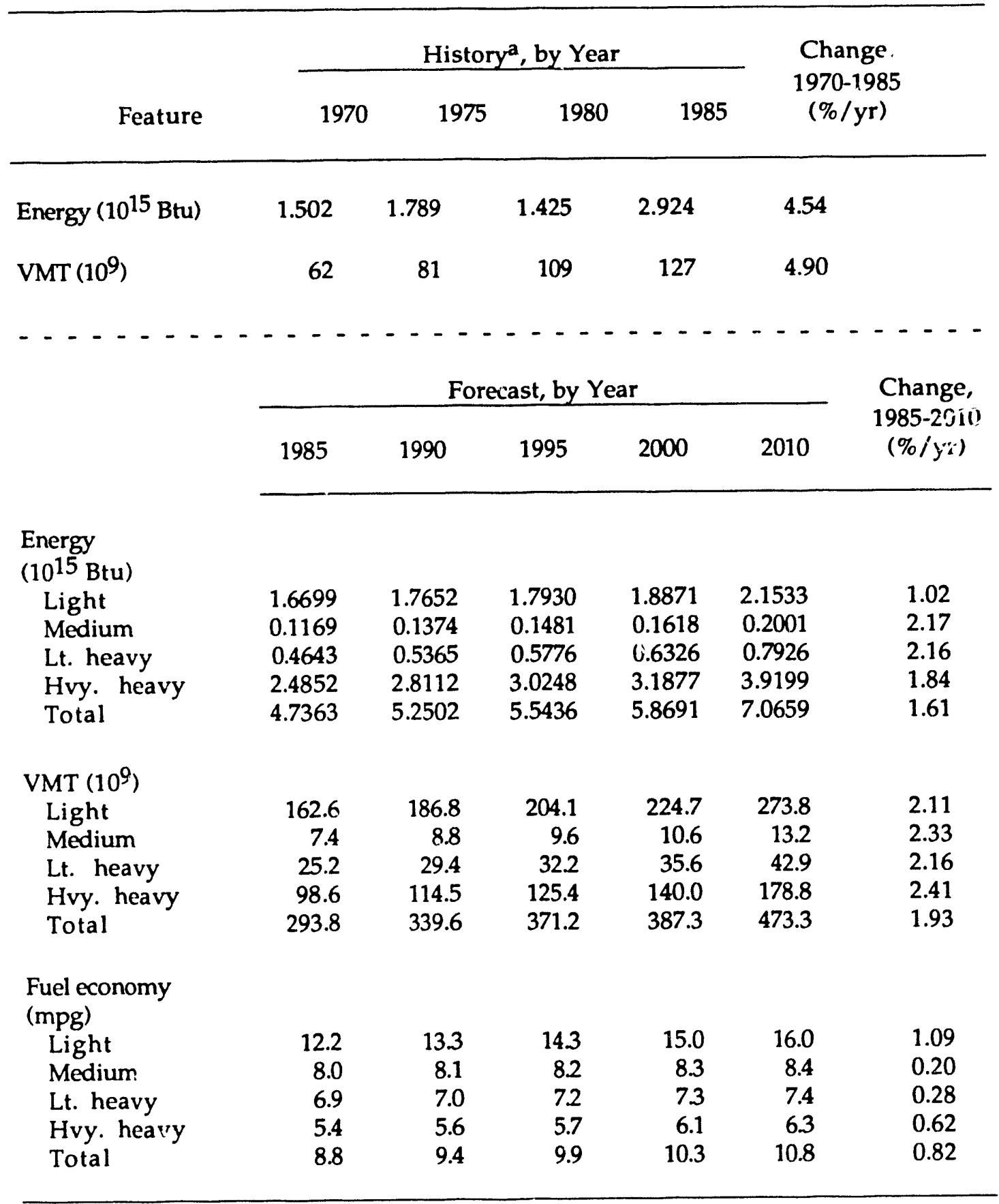

aExcludes light trucks.

Sources: $1970-1985$ from Ref. $43 ; 1990-2010$ from ANL-90N. 
TABLE 3.8 Rail Ton-Miles, Energy Use, and Energy Intensity, 1970-2010

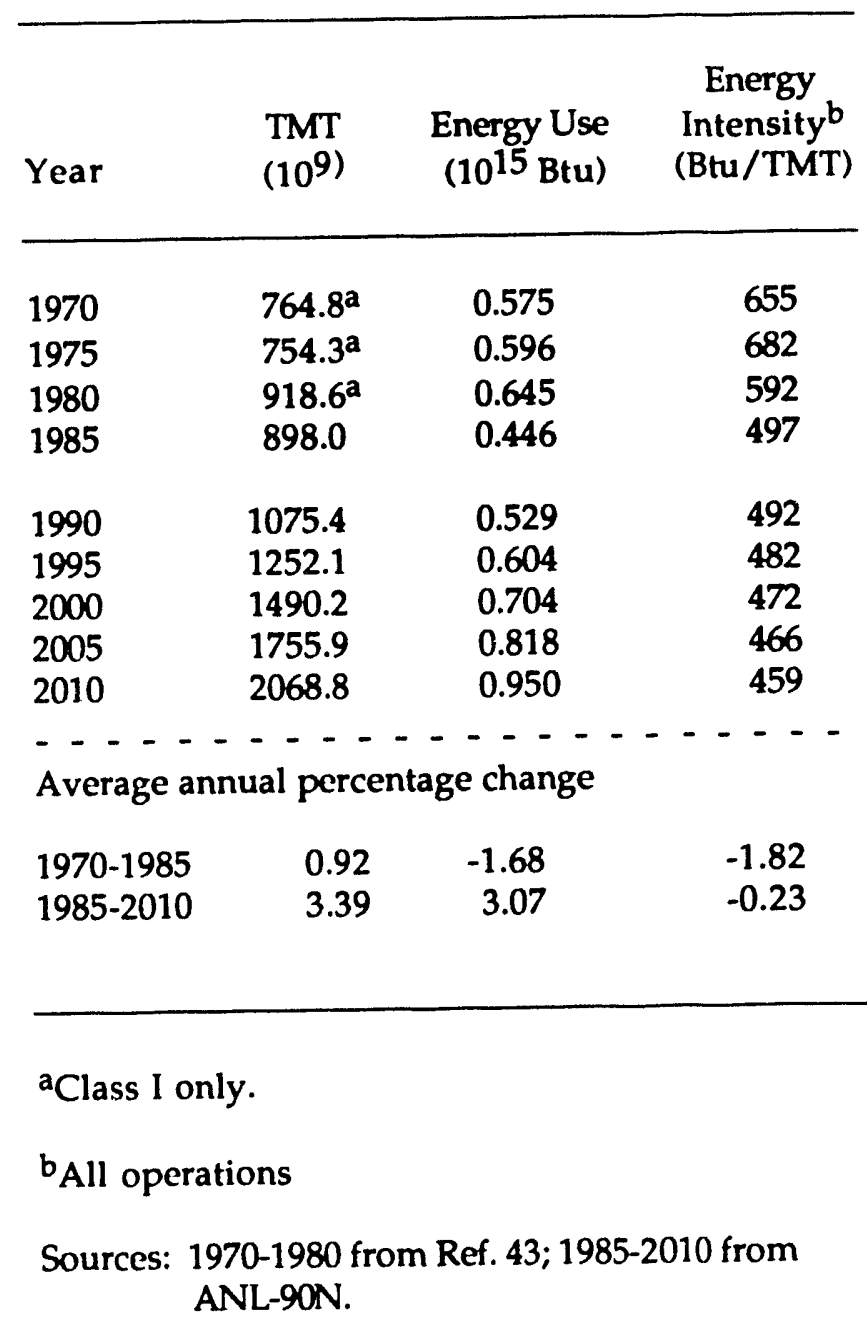

\subsubsection{Input Assumptions}

Rail power units often incorporate relatively old technologies. However, rail energy efficiency is not expected to change much over the forecast period. While there is historical precedent for rapid, dramatic technological changes in rail equipment (e.g., shifts from steam to diesel engines, from hand brakes to air brakes, and from smaller to larger engines that can power "unit" trains), the base case contains no precipitating policy or event to induce such change. Further, because locomotive engines are very long-lived, technological improvements would require upwards of 20 years to produce a discernible impact. Thus, operational improvements were assumed to $b=$ the principal source of future efficiency gains. While research is assumed to continue on methods to use coal, residual oil, and relaxed-specification diesel oil in medium-speed diesel engines, alternative fuels are not considered in the baseline scenario. 
A manufacturer exchange program, in place from the mid-1970s through the mid1980 s at General Motors' Electromotive Division, deserves credit for part of the recent gain in rail energy intensity. Under that program, attractive pricing encouraged railroads to replace rather than rebuild existing power units. However, the program also reduced the potential for further improvement. Since many older two-stroke locomotives were replaced with current-technology two-stroke units between 1975 and 1985, replacement demand is likely to be depressed for some time. Thus, while energy-efficient four-stroke engines are now offered by some manufacturers, ${ }^{71}$ long locomotive lifetimes and a relatively young fleet are likely to slow fleet penetration by the newer engines.

\subsubsection{Results}

Table 3.8 also shows projected rail ton-miles, energy use, and energy intensity. Tonmiles grow faster than in recent years because of business-as-usual conditions (i.e., no major recessions or grain embargoes) and strong growth in such rail-using industrial sectors as coal, chemicals, and agriculture. Note that the output index used to forecast coal ton-miles is based on the coal consumption forecast of the National Energy Policy Plan, 10 and all incremental coal growth is assumed to come from sources west of the Mississippi, which are characterized by longer average lengths of haul. Energy intensity continues to drop, but at a declining rate, from continued line consolidation, classification improvement, and automation of equipment monitoring and utilization.

\subsubsection{Comparison with Other Forecasts}

Because railroads account for less than $2.3 \%$ of the fuel consumed by the transportation sector, few forecasters project rail activity or energy use. Thus, the ANL forecast is compared to only one other effort, that of DOE's Energy Information Administration (EIA). As shown in Table 3.9, EIA expects considerably less growth in rail ton-miles and fuel use, and constant rail fuel efficiency. The EIA's ton-mile forecast is lower because that study expects relatively less growth in coal use, particularly from sources west of the Mississippi. In 1985, coal transport accounted for $9.2 \%$ of rail ton-miles. Because western sources have relatively longer lengths of haul, increases in western coal production result in disproportionate increases in rail ton-miles.

\subsection{MARINE}

Marine energy consumption includes the energy used for domestic waterborne commerce and fuel bunkered by foreign vessels at U.S. ports. In 1985, domestic waterborne commerce (i.e., shipping on the Great Lakes, in U.S. coastal waters, and on inland waterways) accounted for about $4.5 \%$ of transportation energy consumption. Domestic shipping is heavily concentrated in seven bulk commodities: agricultural products, metallic ores, nonmetallic ores, coal, crude oil, chemicals, and petroleum products. In 1985, these 
TABLE 3.9 Forecasts of Rail Freight Ton-Miles, Fuel Consumption, and Fuel Efficiency, 1985-2010

\begin{tabular}{llllllll}
\hline & \multicolumn{7}{c}{ Value, by Year } \\
\cline { 2 - 7 } & 1985 & 1990 & 1995 & 2000 & 2005 & 2010 & $\begin{array}{c}\text { Growth, } \\
1985-2010 \\
(\% / y r)\end{array}$ \\
\hline & & & & & & & \\
TMT (109) & 898 & 1075 & 1252 & 1490 & 1756 & 2069 & 3.39 \\
ANL & $868^{\mathrm{a}}$ & 917 & 993 & 1044 & 1107 & 1187 & 1.43 \\
EIA & & & & & & & \\
Fuel (1015 Btu) & 0.446 & 0.529 & 0.604 & 0.704 & 0.818 & 0.950 & 3.07 \\
ANL & $0.441^{\mathrm{a}}$ & 0.465 & 0.504 & 0.530 & 0.562 & 0.603 & 1.43 \\
EIA & & & & & & & \\
Efficiency (Btu/TMT) & 497 & 492 & 482 & 472 & 466 & 459 & -0.32 \\
ANL & $508^{\mathrm{a}}$ & 507 & 508 & 508 & 508 & 508 & 0 \\
EIA & & & & & & & \\
\hline
\end{tabular}

$a_{1988 .}$

Sources: Ref. 55 and unpublished documentation, ANL-90N.

commodities accounted for more than $95 \%$ of domestic marine ton-miles traveled (TMT); crude oil and petroleum products alone accounted for more than two-thirds of marine TMT. ${ }^{72}$

Recent trends in marine ton-miles, energy use, and energy intensity are summarized in Table 3.10. Between 1975 and 1980 the composition of domestic shipping changed dramatically. As large volumes of Alaskan oil began moving to the lower-48 states, coastal traffic rose sharply and came to account for a far larger share of domestic shipping demand. However, since coastal tankers have relatively more energy-efficient engines and duty cycles than push/tow boats operating in inland waters, this compositional change had virtually no impact on energy consumption. Because the baseline scenario assumes steady declines in Alaskan oil output, the Alaskan oil effect is modeled as a one-time upward shift in demand by the crude oil sector that is slowly eroded over time.

\subsubsection{Input Assumptions}

Like rail locomotives, marine engines (especially those in push/tow boats) are twostroke diesels with long operating lives. Again, current-technology four-stroke units with higher stroke-to-bore ratios may be able to reduce fuel use by $5-10 \%$ or more. ${ }^{71}$ However, short of wholesale engine replacement (which could easily take up to 30 years), 
TABLE 3.10 Domestic Waterborne Freight

Ton-Miles, Energy Use, and Energy Intensity,

1970-2010

\begin{tabular}{|c|c|c|c|}
\hline Year & $\begin{array}{l}\text { TMT } \\
\left(10^{9}\right)\end{array}$ & $\begin{array}{c}\text { Energy Use } \\
\left(10^{15} \mathrm{Btu}\right)\end{array}$ & $\begin{array}{c}\text { Energy } \\
\text { Intensity } \\
(\mathrm{Btu} / \mathrm{TMT})\end{array}$ \\
\hline 1970 & 596 & 0.325 & 545 \\
\hline 1975 & 566 & 0.311 & 549 \\
\hline 1980 & 922 & 0.330 & 358 \\
\hline 1985 & 893.3 & 0.329 & 368 \\
\hline 1990 & 911.1 & 0.337 & 370 \\
\hline 1995 & 898.5 & 0.334 & 372 \\
\hline 2000 & 912.0 & 0.340 & 373 \\
\hline 2010 & 998.7 & 0.376 & 377 \\
\hline \multicolumn{4}{|c|}{ Average annual percentage change } \\
\hline $1970-1985$ & 2.73 & 0.08 & -2.58 \\
\hline $1985-2010$ & 0.45 & 0.54 & 0.10 \\
\hline
\end{tabular}

Sources: $1970-1985$ from Ref. 43; 1990-2010 from ANL-90N.

improvements of some $20-25 \%$ are feasible. Specific technologies that could yield such improvements include crew training in fuel-efficient operating procedures, a manufacturer exchange program like that discussed above for rail transport, and engine replacement with conventional, less powerfui engines (generally fewer units of equal or higher-rated power). Crew training, coupled with use of inline fuel flow meters and implementation of financial incentives for fuel-efficient operations, could be adapted from existing programs designed for truck operators. Depending on the age distribution of existing marine power plants, engine exchange might improve fuel efficiency (in Btu/brake hp-hr) by some $15 \% .72$ Although the savings potential of lower-rated engines is highly dependent on each operation's duty cycle and rated power (both of which are subject to wide variation), substantial savings are likely since diesel engines operate most efficiently at full power and marine engines typically operate well below that point. In the long term, new technologies, such as turbocompounding and rankine bottoming cycles, have demonstrated fuel savings of $5-7 \%$ and approximately $12 \%$, respectively, beyond any other engine-related improvements. $65,66,68$ However, since these technologies are not yet commercially available, and engine replacement cycles are typically 30 years or more, they are not included in the baseline scenario. 


\subsubsection{Results}

Were it not for Alaskan oil development, domestic marine ton-miles, energy intensity, and energy consumption would have been nearly flat in the past. As shown in Table 3.10, ANL-90N forecasts a return to this pattern. Both ton-miles and energy use fluctuate with the changing fortunes of major marine-using industrial sectors. For the most part, growth in agricultural products, coal, ores, and chemicals is balanced against a steady decline in crude oil traffic. The latter is also responsible for near-stable energy intensity. As coastal tankers come to comprise a declining share of domestic marine traffic, the resulting increase in energy intensity is more or less offset by the technical and operational improvements discussed above.

\subsubsection{Comparison with Other Forecasts}

Waterborne transport accounts for a relatively small share of U.S. transportation energy consumption. Thus, few forecasters project maritime activity or energy use. As part of its Annual Energy Outlook, EIA projects fuel use for domestic and international shipping. As shown in Table 3.11, the EIA and ANL forecasts are in relative agreement, projecting slow growth in fuel consumption by domestic shipping and moderate growth by international shipping. Since the two domestic shipping forecasts use virtually the same modeling approach, the small difference between them can be attributed to differences in economic assumptions. Although the two international shipping forecasts use different projection methodologies, the small difference between them is no more pronounced than for domestic shipping.

TABLE 3.11 Projections of Energy Consumed in Waterborne Commerce for Domestic and International Shipping, 1985-2010

\begin{tabular}{|c|c|c|c|c|c|c|c|}
\hline \multirow[b]{2}{*}{ Source } & \multicolumn{6}{|c|}{ Encrgy Consumed $\left(10^{15} \mathrm{Btu}\right)$, by Year } & \multirow{2}{*}{$\begin{array}{c}\text { Growth, } \\
1985-2010 \\
(\% / y r)\end{array}$} \\
\hline & 1985 & 1990 & 1995 & 2000 & 2005 & 2010 & \\
\hline \multicolumn{8}{|l|}{ Domestic } \\
\hline ANL & 0.329 & 0.337 & 0.334 & 0.340 & 0.358 & 0.376 & 0.54 \\
\hline EIA & $0.342^{\mathrm{a}}$ & 0.324 & 0.347 & 0.364 & 0.384 & 0.409 & 0.82 \\
\hline \multicolumn{8}{|l|}{ International } \\
\hline ANL & 0.686 & 0.619 & 0.686 & 0.761 & 0.841 & 0.928 & 1.22 \\
\hline EIA & $0.759^{a}$ & 0.674 & 0.759 & 0.845 & 0.936 & 1.033 & 1.41 \\
\hline
\end{tabular}

a 1988.

Sources: Ref. 55 and unpublished documentation, ANL-90N. 


\subsection{AIR FREIGHT}

\subsubsection{Input Assumptions}

Air cargo is projected as part of the freight demand model discussed above. Within that model, a constant share of ton-miles is allocated between all-cargo aircraft and the cargo hold (belly) of passenger aircraft. "Belly" freight is assigned an energy intensity of zero, since the fuel is already counted in the fuel consumed by passenger aircraft.

Historically, all-cargo aircraft have accounted for about $30 \%$ of air freight ton-miles. This share is expected to grow somewhat as airport congestion restricts carriers' ability to haul cargo in the lower holds of passenger aircraft (e.g., by banning unloading during daytime hours) and lower-cost "minihubs" offer attractive alternatives. Thus, the baseline scenario assumes the all-cargo share grows from to $38 \%$ by 2010.

As for commercial aircraft, the energy intensity of all-cargo aircraft is assumed to improve by a third between 1985 and 2010. (Section 2.3.2 discusses the specific technologies and operating improvements assumed under the baseline scenario.)

\subsubsection{Results}

Table 3.12 presents the ANL-90N forecast, as well as historical trends, in air freight ton-miles. Because the energy consumed in air freight operations is typically not broken out in FAA and other statistics, only ton-miles are shown in the historical time series. Both all-cargo and total energy use and intensity are shown for the projections. Since all-cargo aircraft carry an increasing share of air freight, total energy intensity improves by only $17 \%$ (compared with an overall improvement of $33 \%$ for both passenger and cargo aircraft).

Total ton-miles (i.e., belly plus all-cargo freight) grow by $136 \%$ between 1985 and 2010 . Although somewhat less than historical growth in air freight traffic, this growth rate $(3.5 \% / \mathrm{yr})$ exceeds growth in both economic output and total ton-miles, resulting in an increase in air freight mode share.

\subsection{PIPELINE}

\subsubsection{Input Assumptions}

Pipeline energy consumption (the energy used in sending oil and natural gas through pipelines) has been declining since the early 1970s. Natural gas pipelines account for approximately $75 \%$ of the e:ergy consumed by pipeline transport, and the bulk of the 
TABLE 3.12 Domestic Air Freight Ton-Miles, Energy Use, and Energy Intensity, 1970-2010

\begin{tabular}{|c|c|c|c|c|c|}
\hline \multirow[b]{2}{*}{ Year } & \multirow[b]{2}{*}{$\begin{array}{l}\text { TMTa } \\
\left(10^{9}\right)\end{array}$} & \multicolumn{2}{|c|}{ Energy Use $\left(10^{15} \mathrm{Btu}\right)$} & \multicolumn{2}{|c|}{$\begin{array}{l}\text { Energy Intensity } \\
\text { (Btu/TMT) }\end{array}$} \\
\hline & & Total & All-Cargo & Total $^{b}$ & All-Cargo \\
\hline $\begin{array}{l}1970 \\
1975\end{array}$ & 3.01 & $\begin{array}{l}\text { NAc }^{c} \\
\text { NA }\end{array}$ & NA & $\begin{array}{l}\text { NA } \\
\text { NA }\end{array}$ & $\begin{array}{l}26,821 \\
21,530\end{array}$ \\
\hline $\begin{array}{l}1975 \\
1980\end{array}$ & $\begin{array}{l}3.47 \\
4.53\end{array}$ & $\begin{array}{l}\text { NA } \\
\text { NA }\end{array}$ & NA & NA & $23,750^{d}$ \\
\hline 1985 & 6.16 & 0.061 & 0.040 & 9903 & 21,670 \\
\hline 1990 & 7.75 & 0.074 & 0.047 & 9548 & 18,809 \\
\hline 1995 & 8.93 & 0.082 & 0.049 & 9183 & 16,255 \\
\hline 2000 & 10.42 & 0.092 & 0.053 & 8829 & 14,037 \\
\hline 2010 & 14.54 & 0.119 & 0.064 & 8184 & 11,618 \\
\hline \multicolumn{6}{|c|}{$\begin{array}{l}\text { Average annual percentage change } \\
\text { Aven }\end{array}$} \\
\hline $\begin{array}{l}1970-1985 \\
1985-2010\end{array}$ & $\begin{array}{l}4.89 \\
3.50\end{array}$ & $\begin{array}{l}\text { NA } \\
2.71\end{array}$ & $\begin{array}{l}\text { NA } \\
1.9\end{array}$ & $\begin{array}{r}\text { NA } \\
-0.76\end{array}$ & $\begin{array}{l}-1.41 \\
-2.46\end{array}$ \\
\hline
\end{tabular}

aTotal, includes belly freight.

bWeighted average of all-cargo and belly freight. Belly freight assigned a value of zero since fuel is already included in passenger totals.

cNA = data not available.

d1979.

Sources: $1970-1980$ from Ref. 43; 1985-2010 from ANL-90N.

decline is in that sector. Between 1970 and 1985, domestic production and consumption of natural gas declined by $18 \%$, while the energy consumed by natural gas pipeline transport declined by nearly $30 \%$. Although some technical improvements may have been realized, the bulk of the reduction in energy use is attributed to increases in trunk pipelines' share of total throughput.

Although further improvements in energy intensity are possible, most operational improvements have already implemented, and the baseline scenario provides little economic incentive for introducing new technologies (e.g., bottoming cycles). Thus, energy intensity is constant in the base case. 


\subsubsection{Results}

Table 3.13 presents the ANL-90N pipeline forecast, along with historical trends in pipeline throughput and energy use. Oil pipeline ton-miles and energy use decline primarily from production declines assumed under the baseline scenario. The baseline scenario reflects NEPP7 assumptions (i.e., fuel prices, production and consumption) for the energy sector. ${ }^{10}$ Gas pipeline consumption holds relatively steady, as does natural gas use in the NEPP7 scenario..

TABLE 3.13 Pipeline Ton-Miles, Energy Use, and Energy Intensity, 1970-2010

\begin{tabular}{|c|c|c|c|c|c|}
\hline \multirow[b]{2}{*}{ Year } & \multicolumn{3}{|c|}{ Oil } & \multirow[b]{2}{*}{$\begin{array}{c}\text { Natural Gas } \\
\text { Energy Use } \\
\left(10^{15} \text { Btu }\right)\end{array}$} & \multirow[b]{2}{*}{$\begin{array}{c}\text { Total } \\
\text { Energy Use } \\
\left(10^{15} \text { Btu }\right)\end{array}$} \\
\hline & $\begin{array}{l}\text { TMTa }^{\mathrm{a}} \\
\left(10^{9}\right)\end{array}$ & $\begin{array}{l}\text { Energy Use } \\
\left(10^{15} \mathrm{Btu}\right)\end{array}$ & $\begin{array}{c}\text { Energy } \\
\text { Intensity } \\
\text { (Btu/TMT) }\end{array}$ & & \\
\hline 1970 & 431.0 & 0.243 & 564 & 0.742 & 0.985 \\
\hline 1975 & 507.0 & 0.243 & 479 & 0.592 & 0.835 \\
\hline 1980 & 588.0 & 0.244 & 415 & 0.645 & 0.889 \\
\hline 1985 & 564.0 & 0.233 & 413 & 0.525 & 0.758 \\
\hline $1985^{a}$ & 564.1 & 0.153 & 271 & 0.504 & 0.657 \\
\hline 1990 & 555.3 & 0.152 & & 0.525 & 0.676 \\
\hline 1995 & 520.2 & 0.143 & & 0.579 & 0.722 \\
\hline 2000 & 493.4 & 0.137 & & 0.596 & 0.733 \\
\hline 2010 & 449.6 & 0.126 & & 0.571 & 0.696 \\
\hline \multicolumn{6}{|c|}{ Average annual percentage change } \\
\hline $1970-1985$ & 1.81 & -2.06 & & -0.23 & -1.73 \\
\hline $1985-2010$ & -0.90 & -0.77 & & 0.50 & 0.23 \\
\hline
\end{tabular}

arom ANL-90N.

Sources: $1970-85$ from Ref. 43; 1990-2010 from ANL-90N, except as noted. 


\section{INTEGRATED ANALYSIS}

\subsection{SECTORAL TOTALS}

\subsubsection{Energy Consumption}

Table 4.1 and Fig. 4.1 present historical and projected energy use by mode. Under the baseline scenario, total transportation energy use rises from an estimated 21.9 quads* in 1990 to 26.0 quads in 2010, an increase of $18.6 \%$. Because efficiency improvements fail to keep pace with increases in travel demand, commercial transportation modes -- especially rail and heavy-duty trucking -- experience the fastest growth in energy use; automobiles experience the slowest growth as older, less fuel-efficient vehicles continue to be retired from use. Because of these divergent trends in fuel use by personal and commercial transportation, commercial modes surpass personal modes shortly after the year 2000 and account for the majority of transportation energy use (see Fig. 4.2).

\subsubsection{Fuel Composition}

Gasoline currently constitutes $62.4 \%$ of the petroleum used by the transportation sector. This share is down slightly from $1970(65.3 \%) .76$ The forecast projects continued erosion in this share, with gasoline accounting for just $56.4 \%$ of transportation petroleum consumption by 2010. Since middle distillates -- diesel and jet fuel -- are projected to account for more than 65\% (3.85 quads) of the increase in total sectoral consumption between 1985 and 2010, the middle distillate share is projected to grow from $17.5 \%$ in 1990 to $22.6 \%$ in 2010 . Table 4.2 shows these trends.

The projected increase in diesel fuel use over the period 1990-2010 is about triple the 0.69 -quad increase in jet fuel use for civil aviation. This occurs for several reasons. First, high fuel prices encourage a shift to relatively more fuel-efficient diesel trucks. If heavy trucks maintained the same fuel shares as in 1990, there would have been 0.7 quad less diesel consumption in 2010. Second, projected fuel efficiency gains for the civil aviation fleet are well in excess of those projected for the truck fleet. From 1990 to 2000, energy use per air revenue-passenger-mile (RPM) is projected to drop by a third. For trucks, however, the effects of congestion are anticipated to be even more severe than for passenger cars, since most truck deliveries are projected to continue to occur during peak urban travel periods, while many more passenger car trips will occur during off-peak hours. Our estimate of this effect reduces the gain in heavy-truck efficiency to a $15 \%$ reduction in Btu per vehicle-mile. Third, rail energy use is projected to increase by 0.421 quad, a reversal of the declining trend in railroad fuel use observed over the past decade. This increase is primarily due to the energy and economic assumptions of the baseline scenario, -specifically, robust growth in the production of coal and other bulk commodities.

${ }^{*} 1$ quad $=10^{15}$ Btu 
TABLE 4.1 Transportation Energy Use by Mode, 1970-2010

Energy Use ( $10^{15}$ Btu)

\begin{tabular}{|c|c|c|c|c|c|c|c|c|}
\hline \multirow[b]{3}{*}{ Year } & \multicolumn{3}{|c|}{ Highway Modes } & \multirow{2}{*}{\multicolumn{4}{|c|}{ Nonhighway Modes }} & \multirow[b]{3}{*}{ Total } \\
\hline & \multirow[b]{2}{*}{ Auto } & \multirow{2}{*}{$\begin{array}{l}\text { Lt. } \\
\text { Truck }\end{array}$} & \multirow{2}{*}{$\begin{array}{l}\text { Hvy. } \\
\text { Truck }\end{array}$} & & & & & \\
\hline & & & & $A i r^{b}$ & Rail' & Marine $^{d}$ & Othere & \\
\hline 1970 & 8.526 & 1.540 & 1.611 & 1.307 & 0.575 & 0.753 & 0.993 & 15.305 \\
\hline 1975 & 9.611 & 2.240 & 1.908 & 1.274 & 0.596 & 0.851 & 0.849 & 17.329 \\
\hline 1980 & 9.037 & 2.951 & 2.564 & 1.528 & 0.645 & 1.677 & 0.915 & 19.317 \\
\hline 1985 & 8.673 & 3.630 & 3.085 & 1.881 & 0.501 & 1.311 & 0.781 & 19.862 \\
\hline 1990 & 9.066 & 3.988 & 3.654 & 2.298 & 0.529 & 0.956 & 0.690 & 21.182 \\
\hline 1995 & 9.365 & 4.337 & 3.927 & 2.544 & 0.604 & 1.020 & 0.737 & 22.533 \\
\hline 2000 & 9.713 & 4.630 & 4.166 & 2.765 & 0.704 & 1.101 & 0.748 & 23.828 \\
\hline 2010 & 9.586 & 4.871 & 5.103 & 2.988 & 0.950 & 1.304 & 0.712 & 25.513 \\
\hline \multicolumn{9}{|c|}{ Average annual percentage change } \\
\hline $1970-1985$ & 0.11 & 5.88 & 4.43 & 2.46 & -0.91 & 3.77 & -1.59 & 1.68 \\
\hline $1990-2010$ & 0.28 & 1.01 & 1.68 & 1.32 & 2.97 & 1.56 & 0.16 & 0.93 \\
\hline
\end{tabular}

ancludes buses.

bPassenger, freight, and general aviation. Includes U.S. fuel purchased by foreign flag carriers. Excludes military.

cFreight only.

dDomestic freight and U.S. fuel purchases for international shipping.

ePipeline, transit, and rail passengers.

Sources: $1970-85$ froin Ref. 43; 1990-2010 from ANL-90N.

Table 4.3 disaggregates historical and projected gasoline and diesel fuel use. Gasoline cannot be disaggregated into auto vs. light truck totals for each of the years shown because the time-series data compiled by the Federal Highway Administration 36 provide only aggregate totals (i.e., total consumption by fuel type and total consumption by vehicle type). Nevertheless, the totals for highway gasoline clearly show the impact of fueleconomy improvements in automobiles (particularly since 1980), while totals for diesel trucks show no comparable efficiency gains. The stable-to-declining trend in railroad fuel consumption is also due to the fuel-efficiency effects of various operating improvements 


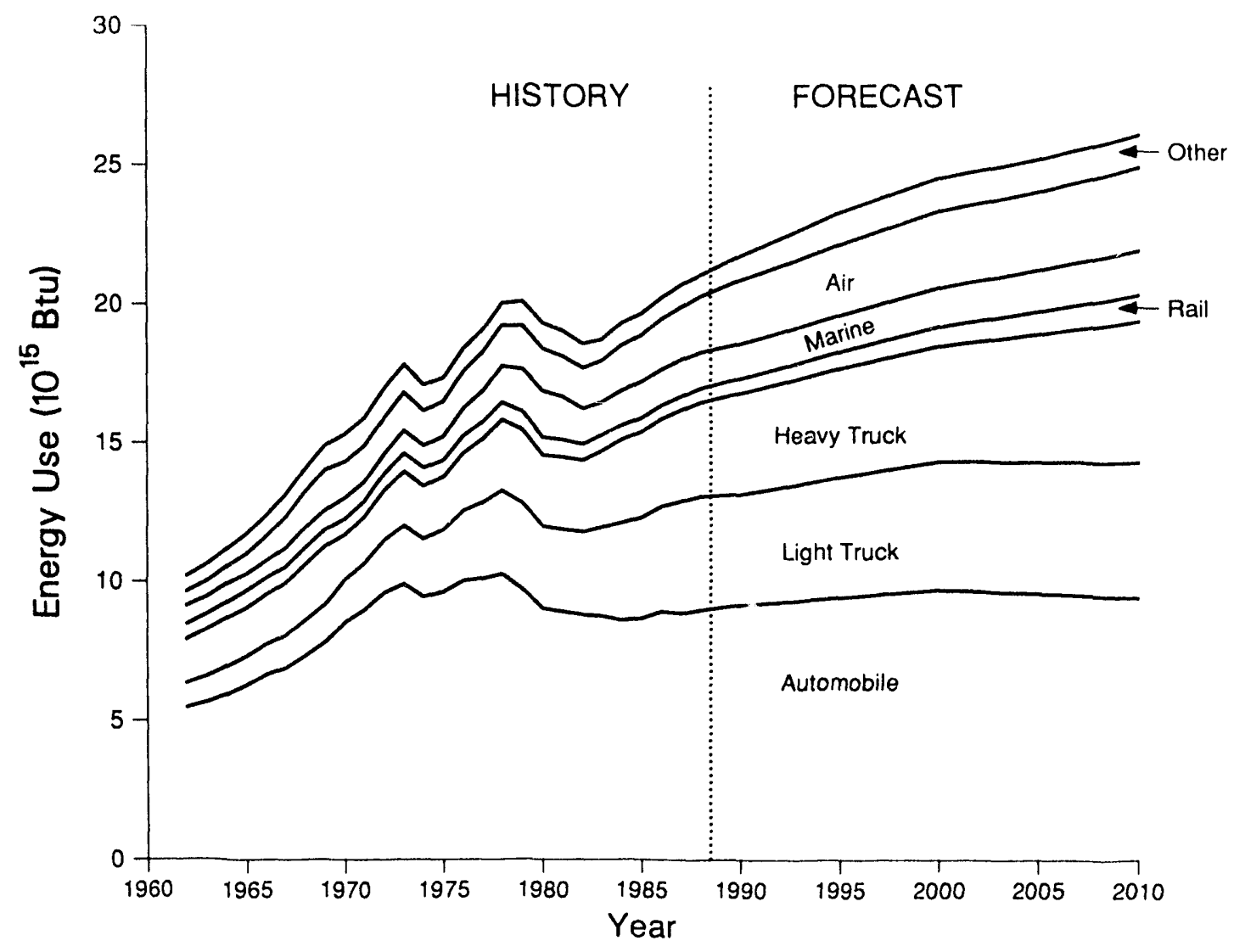

FIGURE 4.1 Transportation Energy Consumption by Mode, 1960-2010

made possible by the mergers, acquisitions, and line consolidations that followed deregulation of the industry (for additional detail, see Sec. 3.3).

\subsubsection{Activity Levels}

Table 4.4 summarizes historical and projected trends in transportation activity -vehicle-miles of travel for highway modes and ton-miles or passenger-miles of travel for nonhighway modes. Stripped of efficiency assumptions, the forecast shows slow and steady moderation in travel growth, particularly for passenger modes. Relatively slow population growth, the aging of the "baby boom" and other population segments, and only modest increases in personal income depress growth in personal travel demand. With increasing traffic congestion, telecommunications substitutes for a growing share of local trips. Longdistance trips continue to be by the same modes, but absent the "extraordinary" events responsible for much of their recent performance, growth slows to more moderate levels. "Extraordinary" events include airline, rail, and motor carrier deregulation; the near total shift to diesel engines in class 8 trucks; the development of Alaskan oil fields, which rapidly boosted coastal tanker traffic; and tighter regulations on the fuel economy, emissions, and 


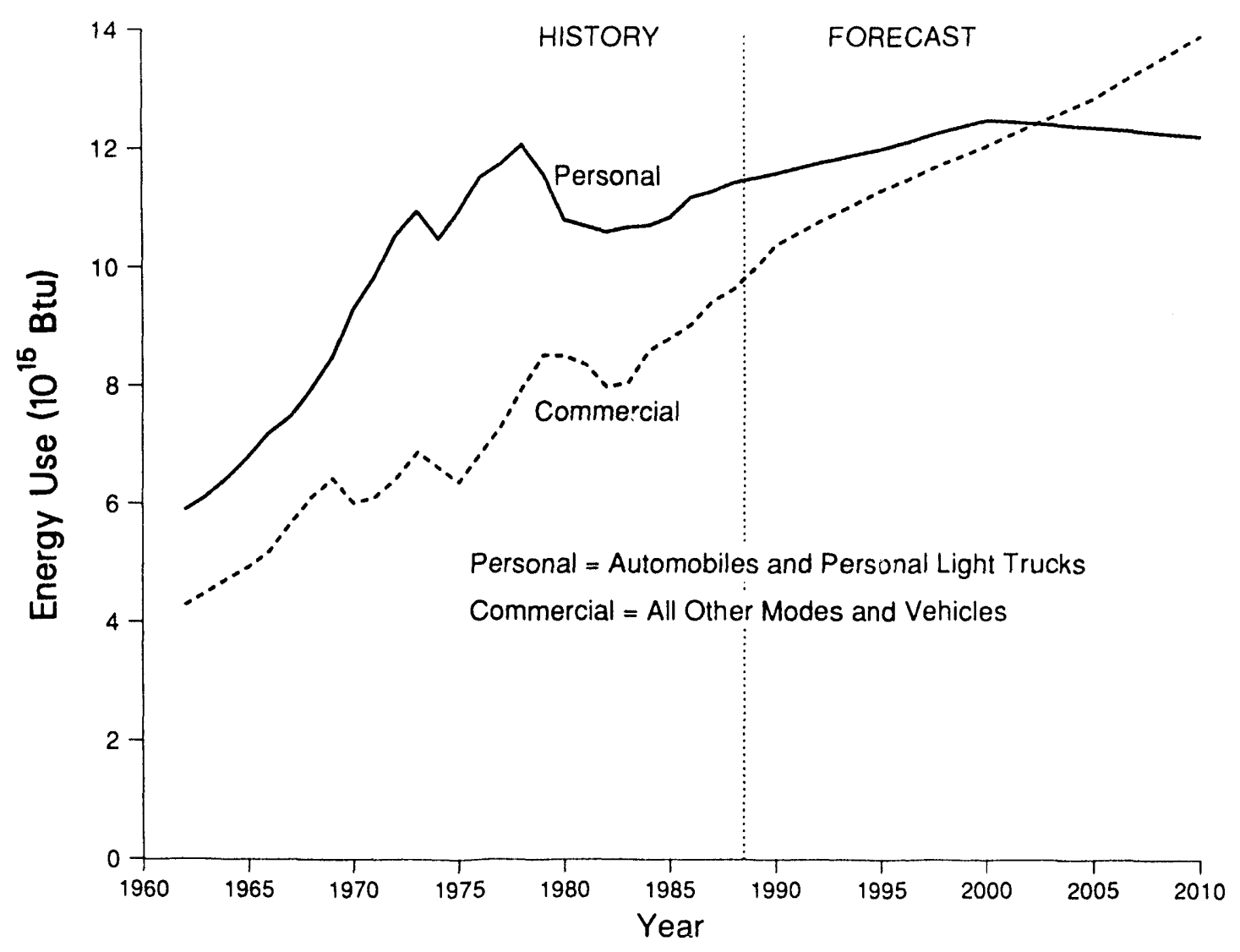

FIGURE 4.2 Personal Versus Commercial Vehicle Energy Use, 1960-2010

safety of cars than of light trucks, which in turn increased price, performance, and capacity disparities (and altered consumer preferences). The sole "extraordinary" event included in the baseline scenario is the growth in coal use forecast by the National Energy Policy Plan. ${ }^{10}$ Because we assume that all incremental coal production comes from sources west of the Mississippi, relatively longer lengths of haul result in a disproportionate increase in rail ton-miles traveled, even if much of the increased coal traffic is transhipped to waterborne modes.

\subsubsection{Vehicle Storks and Efficiency}

Growth of vehicle stocks is comparable to that of travel demand over the forecast period. As shown in Table 4.5, stocks of autos and light trucks grow at much the same rate as do miles traveled by these vehicles (see Table 4.4). Within and between each of these categories, however, there is considerable variation. Trucks in general, and personal light trucks in particular, experience the strongest growth. Automotive stocks grow at a slower rate, but one that is still well above what might be considered a saturation level. 
TABLE 4.2 Transportation Energy Consumption by Type of Fuel, 1970-2010

\begin{tabular}{|c|c|c|c|c|c|c|}
\hline \multirow[b]{2}{*}{ Year } & \multicolumn{6}{|c|}{ Energy Consumption $\left(10^{15} \mathrm{Btu}\right)$, by Fuel Type } \\
\hline & Gasoline & Diesel $^{\mathbf{a}}$ & Jet Fuel ${ }^{b}$ & $\begin{array}{c}\text { Residual } \\
\text { Oil }\end{array}$ & $\begin{array}{c}\text { Natural } \\
\text { Gas }\end{array}$ & Totalc \\
\hline 1970 & 10.49 & 1.64 & 1.36 & 0.58 & 0.74 & 16.07 \\
\hline 1975 & 12.17 & 2.11 & 1.28 & 0.61 & 0.59 & 18.24 \\
\hline 1980 & 12.38 & 2.78 & 2.18 & 1.40 & 0.65 & 19.69 \\
\hline 1985 & 12.78 & 3.20 & 2.50 & 0.82 & 0.52 & 20.12 \\
\hline 1990 & 13.60 & 3.84 & 2.98 & 0.76 & 0.53 & 21.86 \\
\hline 1995 & 14.23 & 4.20 & 3.23 & 0.82 & 0.58 & 23.21 \\
\hline 2000 & 14.80 & 4.61 & 3.45 & 0.90 & 0.60 & 24.51 \\
\hline 2010 & 14.85 & 5.88 & 3.67 & 1.08 & 0.57 & 26.20 \\
\hline \multicolumn{7}{|c|}{ Average annual percentage change } \\
\hline $1970-1985$ & 1.33 & 4.56 & 4.14 & 2.34 & -2.32 & 1.51 \\
\hline $1990-2010$ & 0.44 & 2.15 & 1.05 & 1.77 & 0.36 & 0.91 \\
\hline
\end{tabular}

aExcludes off-highway use, except by zail and marine vessels.

bIncludes general aviation, U.S. fuel purchased by foreign-flag carriers, and military consunption.

CTotal includes electricity, LPG, lubricants, asphalt, etc. Excludes electricity conversion and distribution losst's.

Sources: 1970-1985 from Refs. 36, 42, 43, and 76; 1990-2010 from ANL-90N.

Fuel economy increases modestly for all categories of vehicles. Automobiles improve somewhat more than light trucks, but the biggest difference is between light- and heavy-duty vi.hicles. As discussed in Sec. 3.2, increasing traffic congestion and modest technological improvement constrain fuel efficiency of heavy trucks.

\subsection{SENSITIVITY ANALYSES}

To date, two sets of sensitivity analyses have been performed. In the first set, demographic and travel assumptions were adjusted to examine the effects of an aging population on transportation activity and fuel use; in the second set, travel cost was altered to reflect higher oil prices. 
TABLE 4.3 Gasoline and Diesel Use by Mode, 1970-2010

\begin{tabular}{|c|c|c|c|c|c|c|}
\hline \multirow[b]{2}{*}{ Year } & \multicolumn{2}{|c|}{ Gasoline $^{a}\left(10^{15} \mathrm{Btu}\right)$} & \multicolumn{4}{|c|}{ Diesel (10 15 Btu) } \\
\hline & Highway & Aviation & Truck $^{b}$ & Rail & Marine & Total \\
\hline 1970 & 10.49 & 0.07 & 0.97 & 0.53 & 0.11 & 1.61 \\
\hline 1975 & 12.17 & 0.05 & 1.39 & 0.52 & 0.15 & 2.06 \\
\hline 1980 & 12.38 & 0.06 & 1.97 & 0.55 & 0.21 & 2.73 \\
\hline 1985 & 12.78 & 0.05 & 2.66 & 0.44 & 0.24 & 3.34 \\
\hline 1990 & 13.55 & 0.05 & 3.10 & 0.53 & 0.20 & 3.84 \\
\hline 1995 & 14.17 & 0.06 & 3.40 & 0.60 & 0.20 & 4.20 \\
\hline 2000 & 14.74 & 0.06 & 3.71 & 0.70 & 0.20 & 4.61 \\
\hline 2010 & 14.78 & 0.37 & 4.71 & 0.95 & 0.22 & 5.88 \\
\hline \multicolumn{7}{|c|}{ Average annual percentage change } \\
\hline $1970-1985$ & 1.33 & -2.22 & 6.96 & -1.23 & 5.34 & 4.99 \\
\hline $1990-2010$ & 0.44 & 1.70 & 2.11 & 2.96 & 0.48 & 2.15 \\
\hline
\end{tabular}

aExcludes motorcycles, rec zational boats, and other equipment, as well as nonhighway use by agricultural, construction, and other commercial vehicles.

bIncludes relatively small amounts consumed by automobiles, buses, and offhighway vehicles. Assumes all projected bus consumption is diesel.

Sources: 1970-1985 from Refs. 36, 42, 43, and 76; 1990-2010 from ANL-90N.

\subsubsection{Demographic Shifts}

As the distribution of the U.S. population shifts into age groups with historically lower travel demand, vehicle-miles traveled (and energy use) should decline on a percapita basis. The U.S. population will age over the next two decades, producing an unprecedented number of senior citizens whose travel demands will differ from their current levels (i.e., the travel deinands of "empty nesters," persons 55-65 years of age), as well as from those of their counterparts already over 65 . "Empty nesters" are rnore likely to hold drivers licenses and to have higher incomes than are today's senior citizens. The key question is: How much can the VMT-inducing effects of more driver licenses and higher incomes offset the VMT-reducing effects of fewer work trips, smaller household sizes, and reduced retirement incomes? 


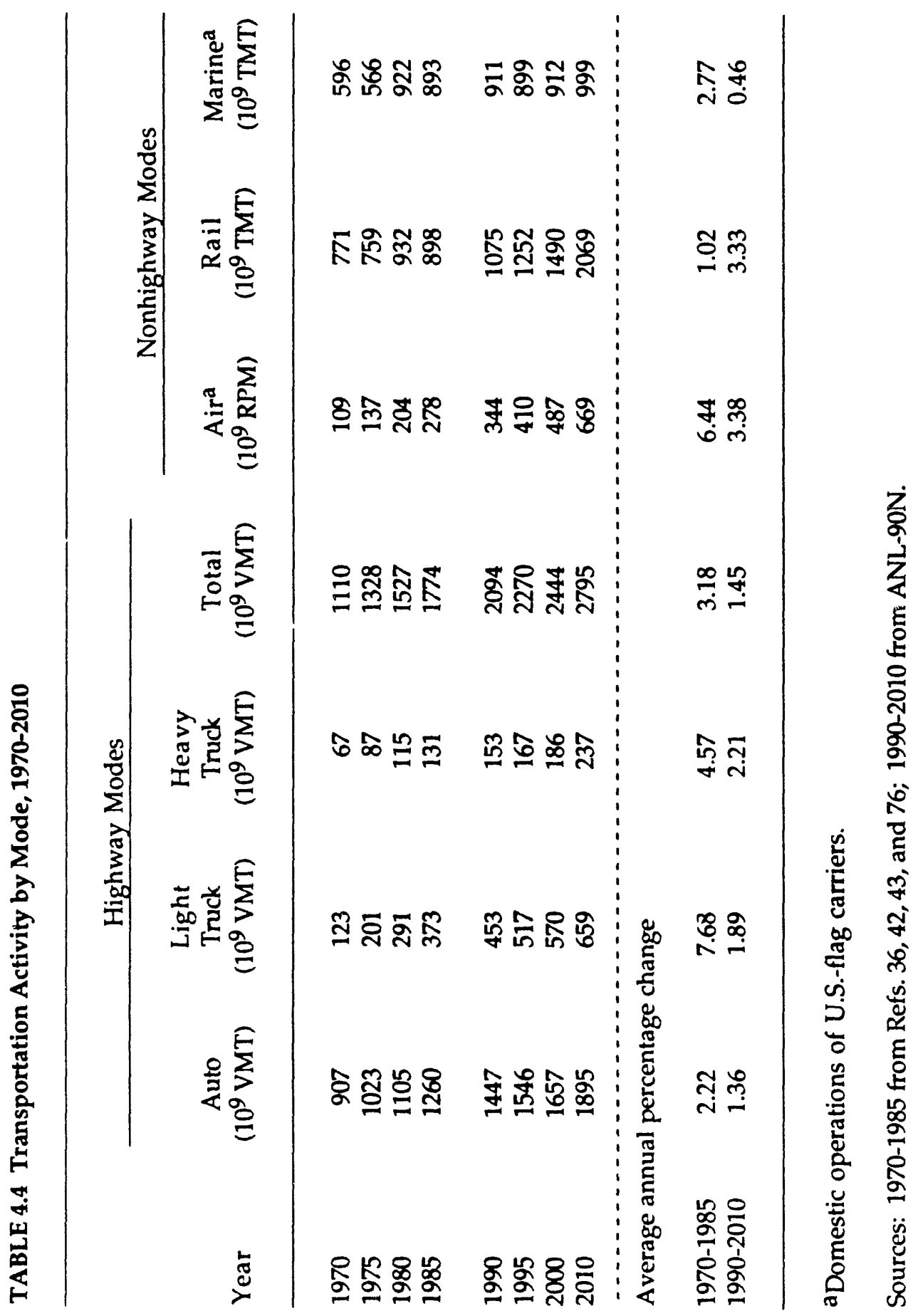


TABLE 4.5 Motor Vehicle Stocks and Fuel Economy, 1985-2010

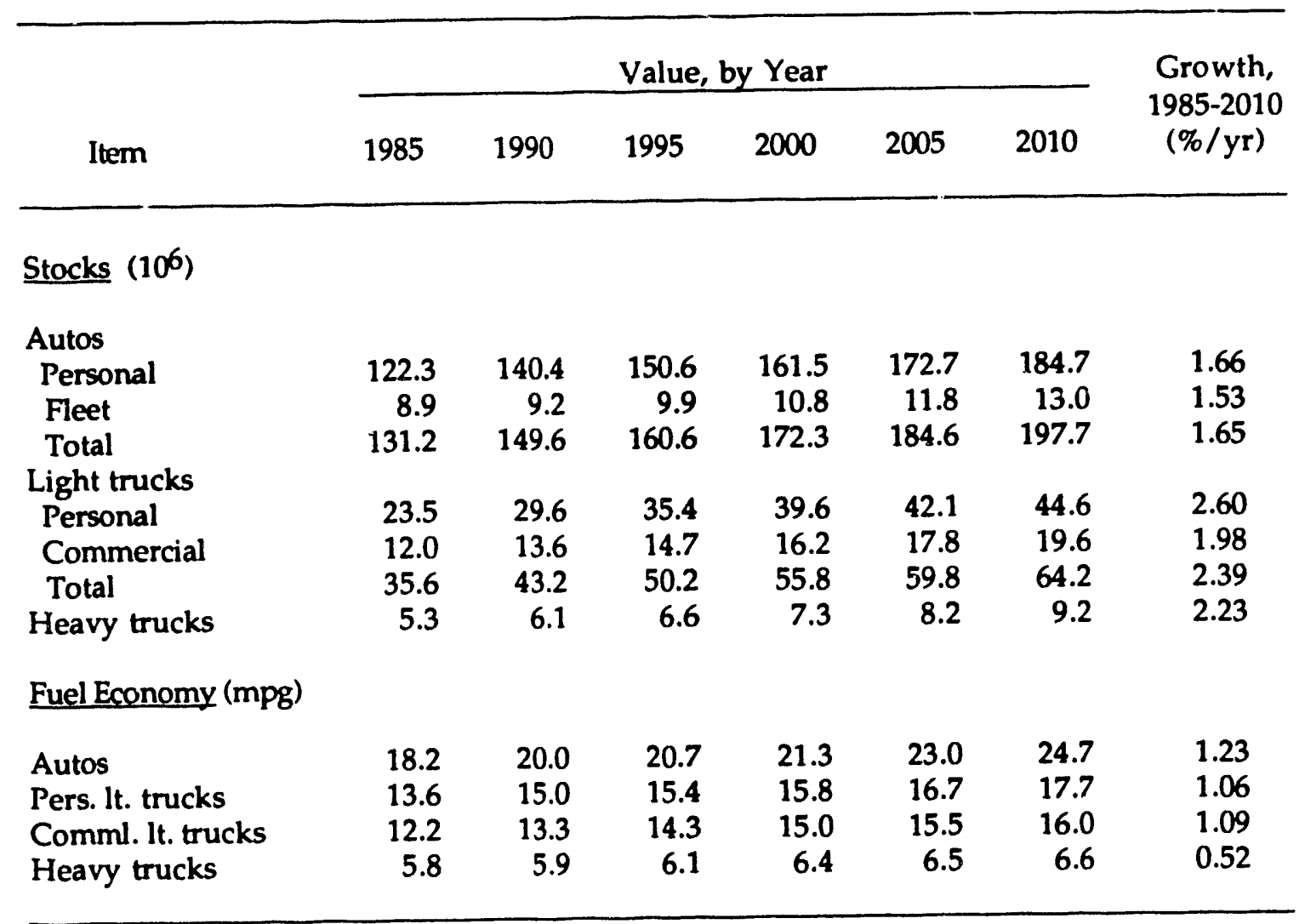

Source: ANL-90N.

A series of sensitivity runs was devised to explore this question. Each run involved the full set of personal travel models, including the vehicle choice model. For each run, a household distribution was adjusted to retain the characteristics of the age cohort that heretofore had been assumeu to change as they aged (i.e., moved into older cohorts). Adjustments were made singly to identify their incremental effect on VMT and energy use. Beginning with travel rates (i.e., VMT per household), a new forecast was generated to correspond with the adjusted, constant inputs. Thus, forecasts were generated to correspond to the travel rates, drivers licensing patterns, and income distributions of households as reported in the base year.

Because the aging of the population is expected to have its greatest impact in the years beyond 2010 (i.e., when the "baby boom" cohort born between 1945 and 1965 reaches retirement age), results are compared not to the baseline scenario, but to another ANL forecast developed for an analysis of global warming. ${ }^{58}$ That forecast extends to 2030. Though somewhat different from the baseline scenario, the relative magnitude and direction of change should be consistent with the baseline. 
Table 4.6 summarizes the changes in VMT and fuel use revealed by these sensitivity runs. Each case is compared to a reference scenario. The cases are as follows:

- Constant VMT per cohort: Households are assumed to retain the same travel rates as they pass into older cohorts. Thus, 1985 empirical results are held constant for each household cohort.

- Constant drivers: In addition to constant travel rates, the 1985 distribution of households by number of drivers licenses held is assumed to remain constant (for households of each size). In other words, households are assumed to retain their driving privileges as they age.

- Constant income: Household income generally follows a normal distribution, rising through age 50 or so, then leveling off and declining with retirement. For this case, income was frozen at 1985 levels, thereby inducing more travel by older cohorts (but less by younger cohorts). Again, constant income was added to constant VMT and drivers licensing rates.

TABLE 4.6 Sensitivity to Travel Assumptions: Comparison of Personal Travel and Fuel Use for Alternative Demographic Inputs

\begin{tabular}{ccccc}
\hline & & \multicolumn{3}{c}{$\begin{array}{c}\text { Change Relative to } \\
\text { Reference Case }\end{array}$} \\
\cline { 3 - 5 } & & Reference \\
Item/ & $\begin{array}{c}\text { Constant } \\
\text { VMT }\end{array}$ & $\begin{array}{c}\text { Constant } \\
\text { Drivers }\end{array}$ & $\begin{array}{c}\text { Constant } \\
\text { Income }\end{array}$ \\
\hline & & & & \\
\hline VMT $^{\mathrm{a}}$ & & & & \\
1995 & 1629 & 1.91 & 2.12 & 4.39 \\
2000 & 1707 & 1.95 & 2.08 & 4.36 \\
2010 & 1947 & 6.30 & 6.69 & 7.86 \\
2020 & 2162 & 8.16 & 9.39 & 12.55 \\
2030 & 2334 & 8.30 & 9.58 & 12.47 \\
& & & & \\
Fuel use & & & & 4.47 \\
1995 & 10.65 & 1.95 & 2.18 & 4.46 \\
2000 & 10.90 & 2.01 & 2.15 & 7.91 \\
2010 & 10.82 & 6.41 & 6.79 & 12.72 \\
2020 & 10.19 & 8.31 & 9.57 & \\
2030 & 10.02 & 8.54 & 9.85 & 12.75 \\
\hline
\end{tabular}

a In $10^{9} \mathrm{VMT}$ for reference case.

$b_{\text {In quads }}\left(10^{15} \mathrm{Btu}\right)$ for reference case. 
Because vehicle preferences are still assumed to change as households age, differences in energy use across the four cases are almost entirely attributable to VMT. As shown in the table, the assumption of constant drivers adds relatively few VMT once household travel rates are controlled. By contrast, income is far more significant, boosting VMT by another $3.2 \%$ in 2020 .

While the assumptions embodied in the baseline scenario are our "best guess" of future travel patterns and preferences, the baseline (like any forecast) is subject to considerable error. In this sense, the results of this sensitivity analysis can be used to define an upper bound on some of that error. Although it is unlikely that all three of these assumptions are superior to the baseline, this exercise shows that the impact of such a case would be on the order of $8 \%$ additional VMT in the year 2010 .

\subsubsection{Fuel Price}

Although an alternative oil price path was not examined in conjunction with the baseline scenario, a concurrently developed set of projections illustrates the impact of alternative oil prices. Termed ORNL/NES, this other projection was part of a preliminary analysis of energy efficiency options developed in late 1989 for the National Energy Strategy. It incorporates the same demographic assumptions as the baseline scenario, but assumes considerably higher oil prices. ${ }^{77}$

As shown in Table 4.7, fuel prices are not uniformly higher in the ORNL/NES price scenario. In 2010, gasoline exhibits the largest price differential $(16.9 \%)$ relative to the baseline. Diesel price differentials (13.7\%) are somewhat less, although still substantial, while jet fuel is only $2.2 \%$ more expensive under ORNL/NES. The resulting energy forecast shows virtually no change for freight and air travel, but a $13.9 \%$ decline in fuel use for personal travel. Much of this decline results from increased vehicle fuel economy. Because vehicle characteristics were assumed to change in response to higher fuel prices, fuel economy improvement is due to both technological changes and consumer responses to higher fuel prices. Conversely, freight travel does not change, because the baseline scenario already incorporates cost-effective vehicle technologies, and diesel price does not rise enough to make additional technologies cost effective.

\subsection{COMPARISON WITH OTHER PROJECTIONS}

The ANL-90N projections for civil aviation, rail, and waterborne transport are compared with other forecasts in Secs. 2.3.4, 3.3.3, and 3.4.3. The ANL-90N projections for automobiles, personal light trucks, and total trucks are compared with other efforts in this section. 


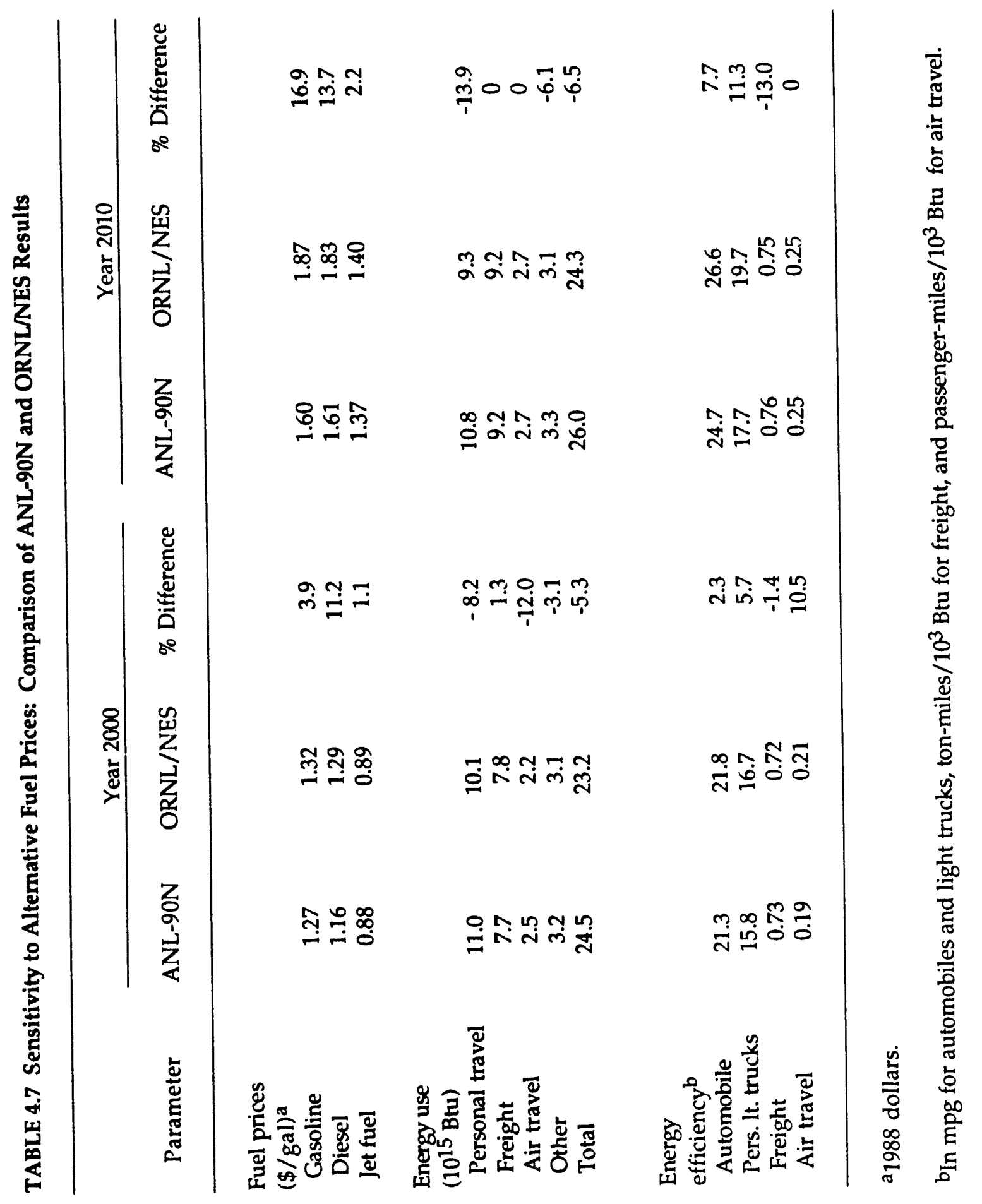


As shown in Fig. 4.3, five recent forecasts are in relative agreement on total highway travel (i.e., VMT by autos, trucks and buses), particularly through the year 2000. In addition to the ANL-90N projections, forecasts by Data Resources, Inc. (DRI), the Gas Research Institute (GRI), Energy and Environmental Analysis (EEA), and the U.S. Department of Energy's Energy Information Administration (EIA) are shown.56-58,78 Although somewhat more dispersed, forecasts of highway energy consumption are also comparatively similar. The EIA forecasts lower energy use in the short term, primarily because of higher fuelefficiency assumptions, but higher energy use by 2010, because of somewhat higher VMT. The GRI forecast of highway energy consumption is the highest of the five, primarily because trucks account for a greater proportion of VMT in those projections.

\subsubsection{Automobiles and Other Personal Vehicles}

The DRI, GRI, and EEA also project auiomobile stocks, VMT, fuel economy, and fuel use. $56,57,78$ The EIA projects the VMT, fuel use, and fuel economy of personal vehicles, as well as new car fuel economy. ${ }^{55}$ Table 4.8 shows these various projections. The table shows that ANL-90N forecasts considerably faster growth in automobile stocks than either DRI or EIA, and somewhat faster growth than EEA, while growth in automotive VMT is virtually

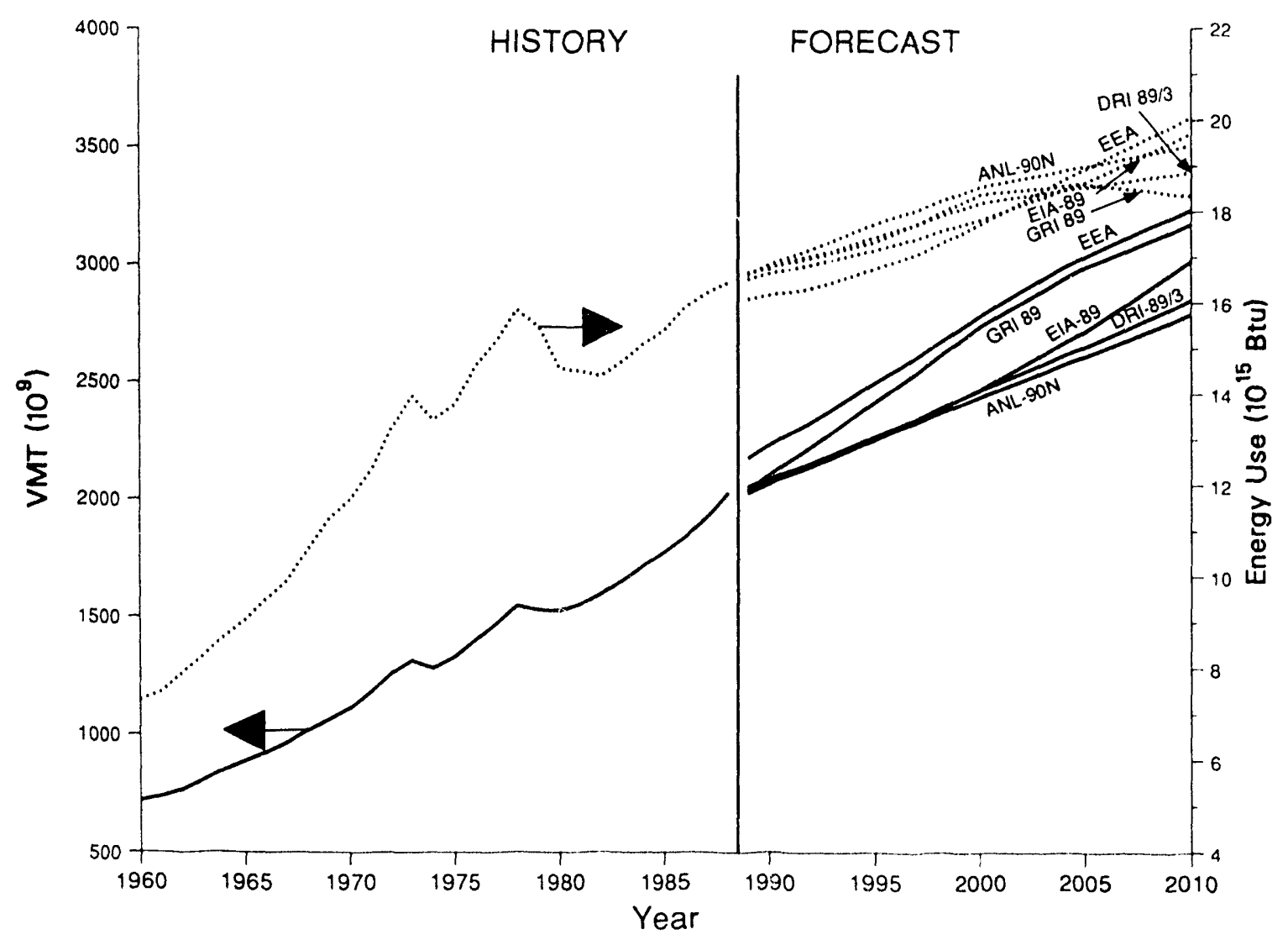

FIGURE 4.3 Highway Travel and Energy Use, 1960-2010 
TABLE 4.8 Forecast Comparisons: Personal Vehicle Stocks, Vehicle-Miles, Fuel Consumption, and Fuel Economy, 1985-2010

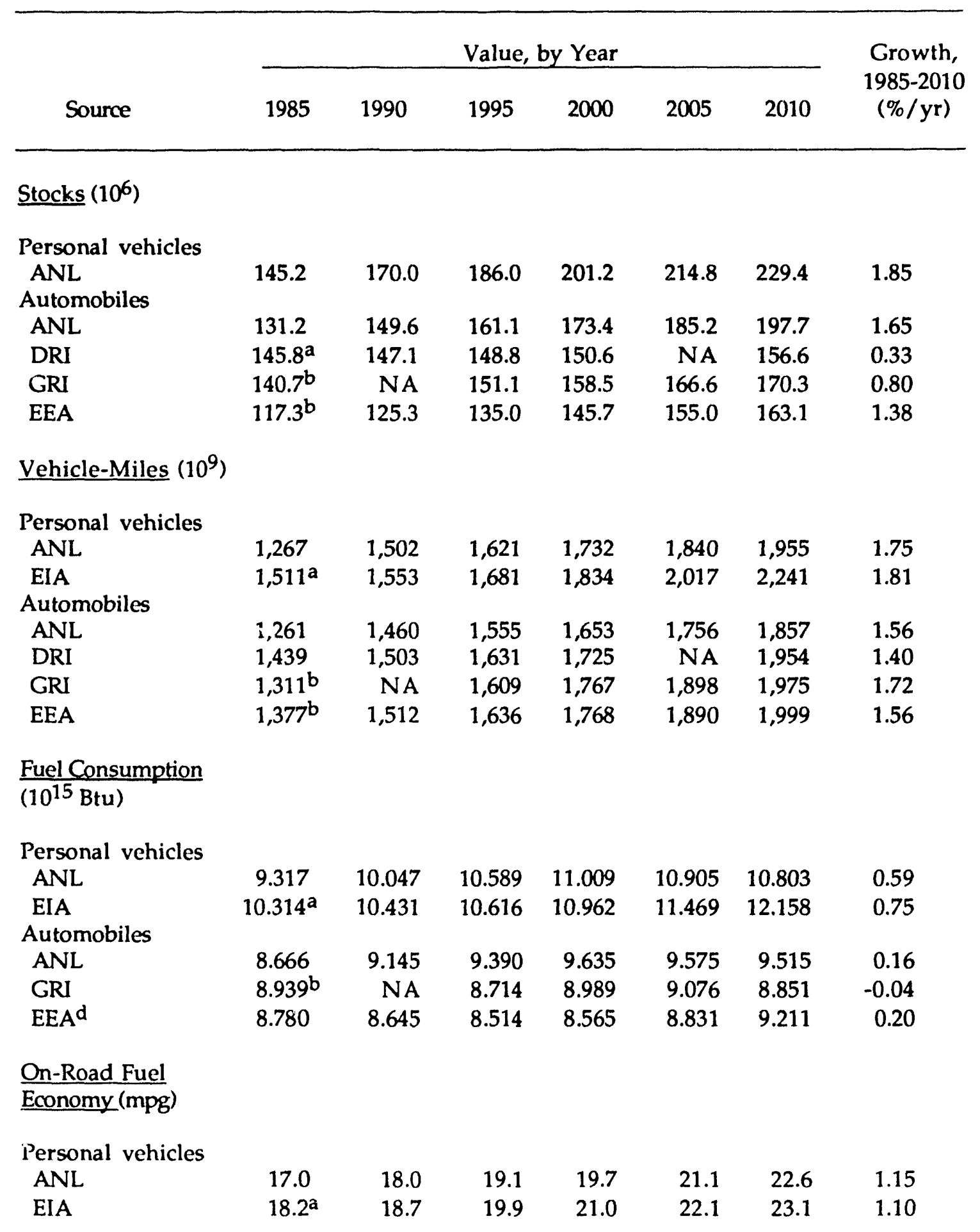


TABLE 4.8 (Cont'd)

\begin{tabular}{|c|c|c|c|c|c|c|c|}
\hline \multirow[b]{2}{*}{ Source } & \multicolumn{6}{|c|}{ Value, by Year } & \multirow{2}{*}{$\begin{array}{c}\text { Growth, } \\
1985-2010 \\
(\% / y r)\end{array}$} \\
\hline & 1985 & 1990 & 1995 & 2000 & 2005 & 2010 & \\
\hline \multicolumn{8}{|c|}{ On-Road Fuel } \\
\hline \multicolumn{8}{|c|}{$\frac{\text { Economy }}{\text { (Cont'd) }}$} \\
\hline \multicolumn{8}{|c|}{ Automobiles } \\
\hline ANL & 18.2 & 20.0 & 20.7 & 21.3 & 23.0 & 24.7 & 1.23 \\
\hline EIA & $19.5^{\mathrm{a}}$ & 20.2 & 22.0 & 23.8 & 25.5 & 27.2 & 1.52 \\
\hline EIA $^{c, e}$ & $28.3^{a}$ & 28.6 & 30.7 & 32.8 & 34.8 & 36.9 & 1.21 \\
\hline DRI & $20.0^{\mathrm{a}}$ & 21.1 & 23.1 & 24.3 & NA & 27.2 & 1.41 \\
\hline $\mathrm{DRI}^{\mathrm{C}}$ & 24.1 & 24.3 & 25.5 & 27.0 & NA & 30.1 & 1.02 \\
\hline GRI & $18.4^{b}$ & NA & 23.1 & 24.6 & 26.2 & 27.9 & 1.75 \\
\hline GRIC & $23.1^{\mathrm{b}}$ & NA & 25.3 & 27.1 & 29.0 & 31.1 & 1.25 \\
\hline EEA & $19.3^{b}$ & 21.4 & 23.1 & 24.3 & 25.0 & 25.2 & 1.12 \\
\hline $\mathrm{EEA}^{\mathrm{c}}$ & $23.8^{\mathrm{b}}$ & 24.3 & 25.1 & 26.5 & 26.5 & 26.5 & 0.45 \\
\hline \multicolumn{8}{|c|}{ Vehicle Utilization } \\
\hline \multicolumn{8}{|c|}{ (VMT/vehicle) } \\
\hline \multicolumn{8}{|c|}{ Personal vehicles } \\
\hline ANL & 8,726 & 8,835 & 8,715 & 8,608 & 8,566 & 8,522 & -0.09 \\
\hline \multicolumn{8}{|c|}{ Automobiles } \\
\hline ANL & 9,611 & 9,759 & 9,652 & 9,533 & 9,482 & 9,393 & -0.09 \\
\hline DRI & $9,870^{\mathrm{a}}$ & 10,218 & 10,961 & 11,454 & NA & 12,478 & 1.07 \\
\hline GRI & $9,318^{b}$ & NA & 10,649 & 11,148 & 11,393 & 12,612 & 1.27 \\
\hline EEA & $11,739^{b}$ & 12,067 & 12,119 & 12,135 & 12,194 & 12,256 & 1.80 \\
\hline
\end{tabular}

$a_{1988 .}$

$b_{1986 .}$

CNew vehicles only.

dExcludes oxygenates.

eEPA rated.

Sources: Refs. 55-57, 78. 
identical across all the forecasts. This pattern occurs because ANL-90N forecasts a $2 \%$ decline in annual VMT per automobile (from 9611 in 1985 to 9393 in 2010), while EEA expects a $4 \%$ increase, and DRI and GRI expect increases of some $26 \%$ and $35 \%$, respectively. Annual VMT/vehicle has been remarkably stable, varying by no more than $2-5 \%$ from the long-term trend over the past 40 years despite economic cycles, demographic shifts, and oil price shocks. ${ }^{79}$

It also should be noted that the stock forecasts used to estimate VMT/vehicle may not be comparable. Some forecasters report total registrations, others use vehicles on the road. Even within these two categories, further variation arises when counts are annual totals versus "snapshot" totals as of year-end or mid-year. Further, the relatively modest growth in automotive stocks apparent in the GRI forecast (and, to a lesser extent, in the EEA forecast) reflects differences in light-truck shares of light-duty vehicles. The GRI and EEA expect continued rapid growth in light trucks, many of which would substitute for automobiles.

The several forecasts are in relative agreement on fuel efficiency. Automotive fuel economy, estimated at $20-21 \mathrm{mpg}$ in 1990 , is expected to rise to $25-28 \mathrm{mpg}$ by 2010 . At $24.7 \mathrm{mpg}$, the ANL forecast is on the low end of the range, while GRI $(27.9 \mathrm{mpg})$ is on the high end. With the exception of EEA, all forecasts expect new car fuel economy to rise from some $24-25 \mathrm{mpg}$ in 1990 to $30-32 \mathrm{mpg}$ in 2010. After discounting for on-road degradation, the EIA forecast, approximately $32.1 \mathrm{mpg}$, is at the top of the range. The EEA values do not really fall outside this range, since they do not forecast new car fuel economy beyond the year 2000 (i.e., the 26.5-mpg level attained in 2000 is held constant for each succeeding year).

Automotive fuel economy is only roughly related to gasoline price. As shown in Fig. 4.4, this has been the case historically, and the forecasts project a similar pattern in the future. The EIA has the highest gasoline prices and projects the highest levels of automotive fuel efficiency through most of the projection period. By contrast, ANL has the lowest automotive fuel economy despite gasoline prices almost identical to those of EIA. Likewise, although DRI has the lowest gasoline prices, fuel efficiency is midway between the projections of ANL and EIA by the year 2010.

As travelers weigh the expense of traveling against their desire to travel, fuel price also influences VMT. Figure 4.5 illustrates this relationship by comparing automotive VMT per capita and fuel cost per mile of travel for the five forecasts.

While variations in technological assumptions produce some variation in travel cost, VMT is largely insensitive to those differences. This is further illustrated by comparing the fuel-cost elasticities of the five forecasts. Since they capture the effect of technological improvement, fuel-cost elasticities tend to be lower than other long-range elasticities, which range to $-0.7 .78,79$ For ANL, DRI, and EIA, elasticities of per-capita automotive VMT to per-mile fuel cost clustered around -0.30. For EEA and GRI, elasticities were calculated at -0.48 and -0.36 , respectively. These elasticities help explain why fuel economy varies more than VMT under the above forecasts. 


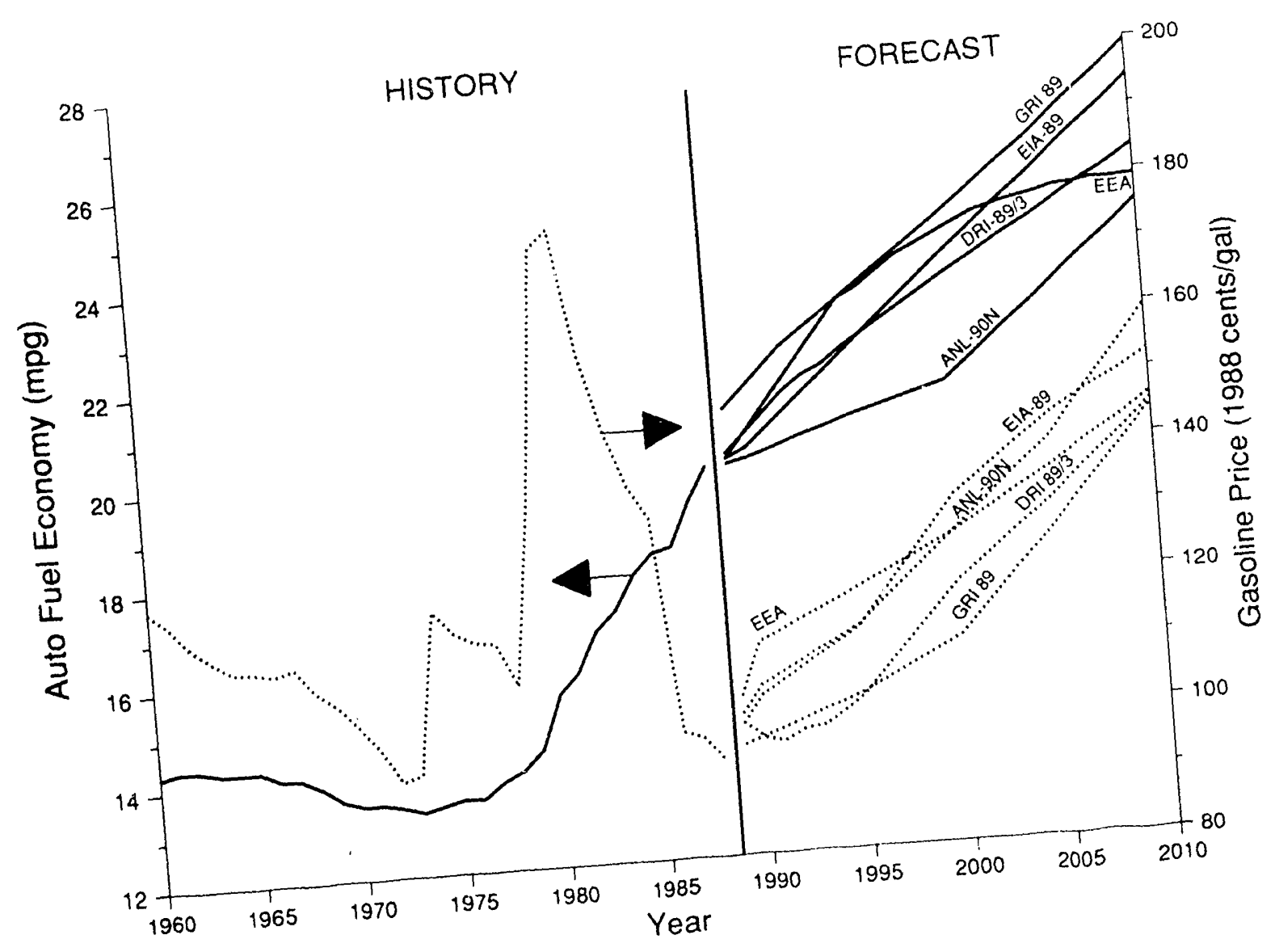

FIGURE 4.4 Automotive Fuel Economy Versus Gasoline Price, 1960-2010

\subsubsection{Trucks}

The DRI, GRI, and EIA also project truck vehicle-miles as an intermediate step in forecasting transportation energy demand. Since the focus of those forecosts ine both ponal and they tend to aggregate across all types and sizes of the ANL-90N forecast of total truck stocks, commercially used vehicles. Table 4.9 Co EIA, and EEA forecasts. With the exception of EIA, VMT, and energy use with the DRly in the base year, presumably from minor vatead of light all forecasts differ only stion (e.g., by classifying minivans and sport utilities as autorical standards) vehicle classification (DRI foresee comparable, relatively GRI (and, to a lesser extent, EEA) growth in total truck stocks and vehicle-miles, wh show relatively comparable growth in forecasts considerably faster growth. All forecas slower growth, their truck forecast fuel consumption (although EIA shows some last portion of the table, the major difference excludes personal vehicies). As shown fuel economy assumptions. The difference between between the four forecasts is in their fuelusion of personal trucks from the latter effort. The ANL and EIA is entirely due to the exclusiovement in fuel economy (particularly for lightGRI anticipates considerably m or EIA. Because the fuel prices used by all four forecasts are

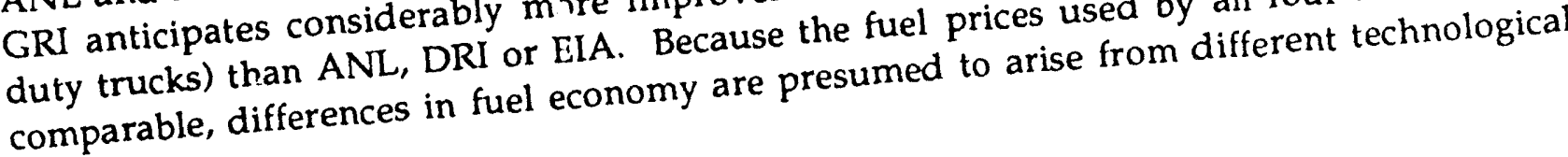




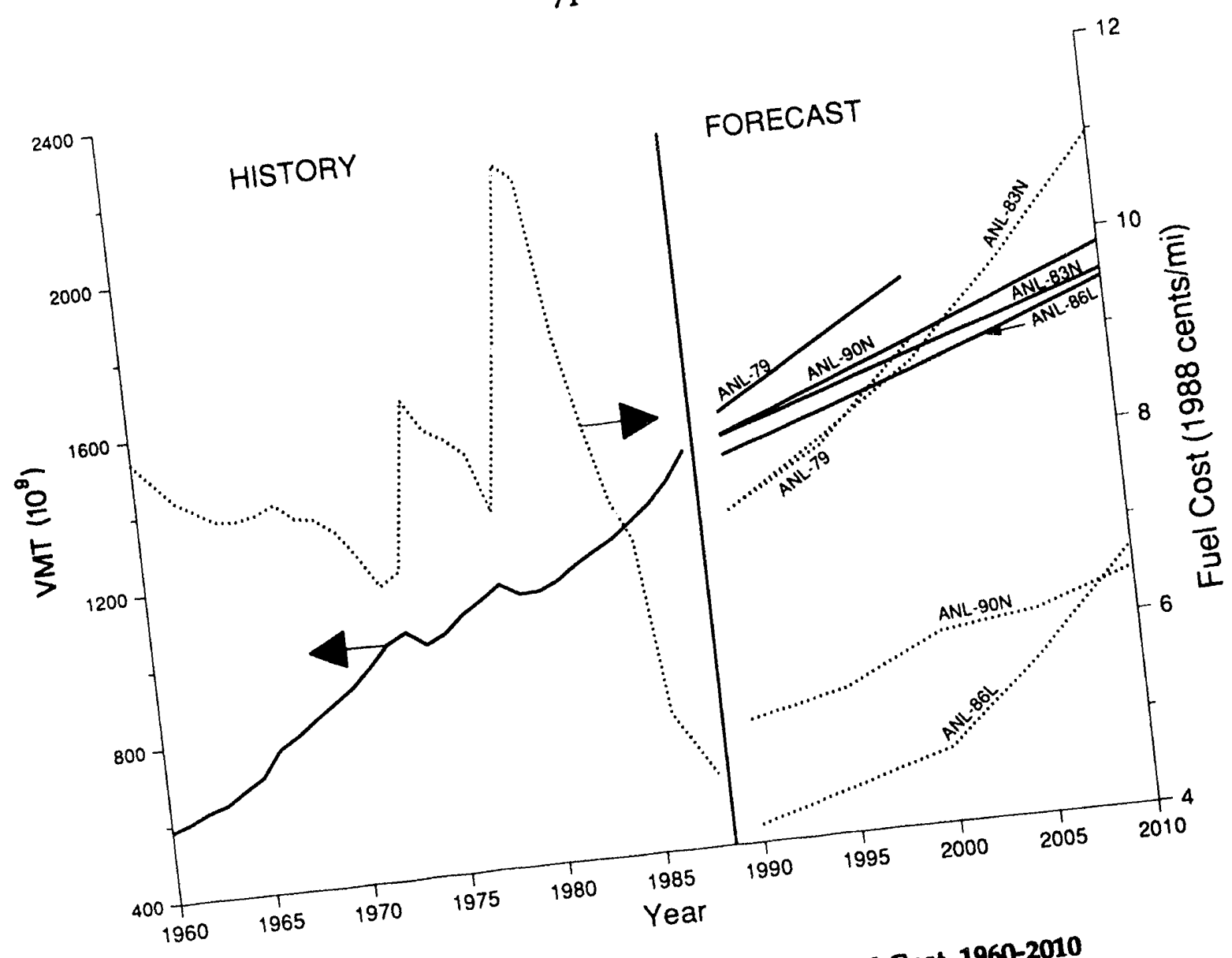
assumptions. With the exception of ANL (see Sec. 3.2.

forats of transportion energy demand under

Since 1979, ANL has produced six forecasts Technologies, as well as several other he sponsorship of DOE's Office of Transpor and Environment and Polcy, Direct Energy forecasts for DOE's $58,59,80$ The first, documented in the a series of separate modal models and Analysis. ${ }^{58,59,80}$ The $1975-2000$ Baseline, utilized a The second, documented in Baseline Consumption by Mode: outputs based on the SEAtion Energy Consumption by Monstortion Energy and Projections of Transportals presently incorporated in somewhat different methodologies for versions of the modSstem (TEEMS), as well as somewhent forecasts used then-current Emissions Modeling Syste characteristics. estimating future
versions of TEEMS models. 
TABLE 4.9 Forecast Comparisons: Truck Stocks, Vehicle-Miles, Fuel Consumption, and Fuel Economy, 1985-2010

\begin{tabular}{lllllllll}
\hline & \multicolumn{1}{c}{} & \multicolumn{4}{c}{ Value, by Year } & Growth, \\
\cline { 2 - 5 } & 1985 & 1990 & 1995 & 2000 & 2005 & 2010 & $\begin{array}{c}\text { 1985-2010 } \\
(\% / y r)\end{array}$ \\
\hline
\end{tabular}

Stocks $\left(10^{6}\right)$

Total trucks

$\begin{array}{llllllll}\text { Total trucks } & 40.9 & 49.3 & 56.8 & 63.1 & 68.0 & 73.4 & 2.37 \\ \text { ANL } & 42.6^{\mathrm{a}} & 46.3 & 52.6 & 59.6 & \text { NA } & 71.9 & 2.41 \\ \text { DRI } & 40.1^{\mathrm{b}} & \text { NA } & 58.9 & 72.5 & 81.9 & 90.2 & 3.44 \\ \text { GRI } & 44.8^{\mathrm{b}} & 54.6 & 65.2 & 76.3 & 84.7 & 89.8 & 2.94 \\ \text { EEA } & & & & & & & \\ \text { Light-duty trucks } & 35.6 & 43.2 & 50.2 & 55.8 & 59.8 & 64.2 & 2.39 \\ \text { ANL } & 39.0^{\mathrm{a}} & 42.7 & 48.7 & 55.2 & \text { NA } & 66.4 & 2.44 \\ \text { DRI } & 36.4^{\mathrm{b}} & \text { NA } & 54.9 & 67.7 & 76.5 & 84.4 & 3.57 \\ \text { GRI } & 37.1^{\mathrm{b}} & 46.0 & 55.7 & 65.9 & 73.7 & 78.3 & 3.16 \\ \text { EEA }^{\mathrm{f}} & & & & & & & \end{array}$

Vehicle-Miles $\left(10^{9}\right)$

Total trucks

$\begin{array}{lllllrrr}\text { Total trucks } & 509 & 612 & 691 & 764 & 830 & 903 & 2.32 \\ \text { ANL } & 303^{\mathrm{a}} & 311 & 347 & 385 & 423 & 469 & 2.08 \\ \text { EIA }^{\mathrm{c}} & 586^{\mathrm{a}} & 630 & 722 & 831 & \text { NA } & 1,021 & 2.56 \\ \text { DRI } & 524^{\mathrm{b}} & \text { NA } & 802 & 968 & 1,087 & 1,193 & 3.49 \\ \text { GRI } & & & & & & & \\ \text { Light-duty trucks } & 372 & 453 & 517 & 570 & 613 & 659 & 2.31 \\ \text { ANL } & 399 \mathrm{~b} & 509 & 620 & 734 & 825 & 881 & 3.36 \\ \text { EEA }^{\mathrm{f}} & & & & & & \end{array}$

Fuel Consumption $\left(10^{15} \mathrm{Btu}\right)$

Total trucks

$\begin{array}{llrrrrrr}\text { ANL } & 6.657 & 7.469 & 8.080 & 8.598 & 9.150 & 9.767 & 1.55 \\ \text { EIA }^{\mathrm{c}} & 4.724^{\mathrm{a}} & 4.860 & 5.154 & 5.434 & 5.667 & 5.961 & 1.06 \\ \text { DRI } & 7.542^{\mathrm{a}} & 7.860 & 8.655 & 9.616 & \text { NA } & 10.418 & 1.48 \\ \text { GRI } & 6.970^{\mathrm{b}} & \text { NA } & 8.620 & 9.387 & 9.523 & 9.497 & 1.30 \\ \text { EEAg } & 6.793^{\mathrm{b}} & 7.307 & 7.831 & 8.583 & 9.404 & 10.079 & 1.66 \\ \text { Light-duty trucks } & & & & & & & \\ \text { ANL } & 3.591 & 3.988 & 4.337 & 4.630 & 4.745 & 4.871 & 1.23 \\ \text { EEA }^{\mathrm{f}, \mathrm{g}} & 3.312^{\mathrm{b}} & 3.757 & 4.121 & 4.589 & 5.011 & 5.287 & 1.97\end{array}$


TABLE 4.9 (Cont'd)

\begin{tabular}{|c|c|c|c|c|c|c|c|}
\hline \multirow[b]{2}{*}{ Source } & \multicolumn{6}{|c|}{ Value, by Year } & \multirow{2}{*}{$\begin{array}{c}\text { Growth, } \\
1985-2010 \\
(\% / y r)\end{array}$} \\
\hline & 1985 & 1990 & 1995 & 2000 & 2005 & 2010 & \\
\hline \multicolumn{8}{|c|}{ On-Road Fuel } \\
\hline \multicolumn{8}{|c|}{ Economy (mpg) } \\
\hline \multicolumn{8}{|c|}{ Total trucks } \\
\hline ANL & 10.6 & 11.6 & 12.2 & 12.7 & 13.1 & 13.6 & 1.00 \\
\hline $\mathrm{EIA}^{\mathrm{C}}$ & $8.4^{\mathrm{a}}$ & 8.6 & 9.0 & 9.5 & 10.1 & 10.7 & 1.10 \\
\hline DRI & $10.1^{\mathrm{a}}$ & 10.4 & 10.9 & 11.3 & NA & 12.9 & 1.11 \\
\hline GRI & $9.7 b$ & NA & 12.1 & 13.4 & 14.8 & 16.3 & 2.17 \\
\hline EEA & $11.0^{\mathrm{a}}$ & 12.5 & 13.8 & 14 & 14.9 & 15.0 & 1.30 \\
\hline \multicolumn{8}{|c|}{$\begin{array}{l}\text { EEA } \\
\text { Light-duty truckss }\end{array}$} \\
\hline ANL & 13.0 & 14.2 & 14.9 & 15.4 & 16.2 & 17.0 & 1.08 \\
\hline$E_{1} A^{d}$ & $14.8^{\mathrm{a}}$ & 15.0 & 15.5 & 16.1 & 16.6 & 17.2 & 0.67 \\
\hline EIA $^{d, e}$ & $20.7^{a}$ & 20.6 & 21.5 & 22.1 & 23.1 & 23.9 & 0.65 \\
\hline $\mathrm{DRI}^{\mathbf{e}}$ & $17.8^{a}$ & 17.9 & 19.0 & 20.8 & NA & 25.6 & 1.67 \\
\hline GRIe & $16.0^{b}$ & NA & 19.1 & 21.6 & 24.7 & 28.3 & 2.40 \\
\hline $\mathrm{EEA}^{\mathrm{f}}$ & $14.9^{b}$ & 16.6 & 18.0 & 18.8 & 19.2 & 19.4 & 1.11 \\
\hline \multicolumn{8}{|c|}{ Vehiclf Utilization } \\
\hline \multicolumn{8}{|c|}{ (VMT: vehicle) } \\
\hline \multicolumn{8}{|c|}{ Total trucks } \\
\hline ANL & 12,445 & 12,414 & 12,165 & 12,108 & 12,206 & 12,302 & -0.05 \\
\hline DRI & $13,756^{a}$ & 13,607 & 13,726 & 13,943 & NA & 14,200 & 0.14 \\
\hline GRI & $13,067^{b}$ & NA & 13,616 & 13,352 & 13,272 & 13,226 & 0.05 \\
\hline \multicolumn{8}{|c|}{ Light-duty t ucks } \\
\hline ANL & 10,449 & 10,486 & 10,299 & 10,215 & 10,251 & 10,265 & -0.07 \\
\hline $\mathrm{EEA}^{\mathfrak{f}, \mathrm{g}}$ & $10,755^{b}$ & 11,065 & 11,131 & 11,138 & 11,194 & 11,252 & 0.19 \\
\hline
\end{tabular}

a 1988.

$b_{1986 .}$

cFreight trucks only.

dPersonal vehicles.

eNew vehicles only.

fUnder $8500 \mathrm{lb}$ gross vehicle weight.

gExcludes oxygenates.

Sources: Refs. 55-57, 78. 
To aid comparison and avoid unnecessary duplication, only four of the six forecasts are shown on the following graphs. All graphs include the previous 25 years, both to illustrate the range of historical experience (and, consequently, the variability possible in a trend extrapolation) and to provide a context for the forecasts. Most of the forecasts had different base years. Thus, what appears to be a discontinuity between historical and projected curves on many of the graphs arises from unforeseen events or circumstances between the base year of the forecast and the first data point shown. This is especially true for the earlier efforts.

\subsubsection{Transportation Energy}

Figure 4.6 illustrates the more than doubling of transportation energy use between 1960 and 1985 and the 1979, 1983, 1986, and 1990 ANL forecasts. Undertaken before the second oil price shock, ANL-79 has the strongest growth, followed by the current ANL-90N forecast (also undertaken before the most recent oil price increases). ANL-81 and 85 (not shown) are similar to the ANL-83 forecast.

The 1983 and 1986 forecasts also illustrate the effect of automotive fuel economy assumptions on near-term fuel use. Between 1990 and 200n, these forecasts are nearly flat. Both assumed that 1985 CAFE standards would be met, and vehicle replacement would continue to raise fleet average fuel economy. In contrast, the ANL-90N forecast expects continued difficulty in meeting the 1985 standards, and an increase in the degradation between EPA-test and on-road fuel economy (because of both a greater preponderance of urban driving and worsening traffic congestion).

\subsubsection{Highway Travel}

Figure 4.7 compares total highway vehicle-miles traveled by autos, trucks, and buses with their projected fuel use. Again, ANL-79 shows the highest VMT and fuel use. Further, the similar slopes of the 1979 VMT and fuel-use forecasts indicate relatively conservative fuel economy assumptions. In contrast, the slope of energy use is considerably lower than that of highway VMT in the ANL-83 and, to a lesser extent, ANL-86 forecasts, suggesting less conservatism. In ANL-90N a mixed pattern is evident -- while fueleconomy improvements are not expected to produce absolute reductions in highway fuel use, they do restrain its growth, particularly in the near term.

For automobiles, a somewhat different pattern emerges from the several projections. As shown in Fig. 4.8, automotive VMT forecasts occupy a relatively narrow band, despite wide variaticns in the cost of travel (i.e., fuel cost/mile). This insensitivity to fuel cost is rcughly comparable to the short-term eiasticities reported in the literature ${ }^{81-83}$ Note that fuel cost per mile already incorporates the effect of any increases or decreases in automotive fuel economy likely to result from changes in gasoline prices. 


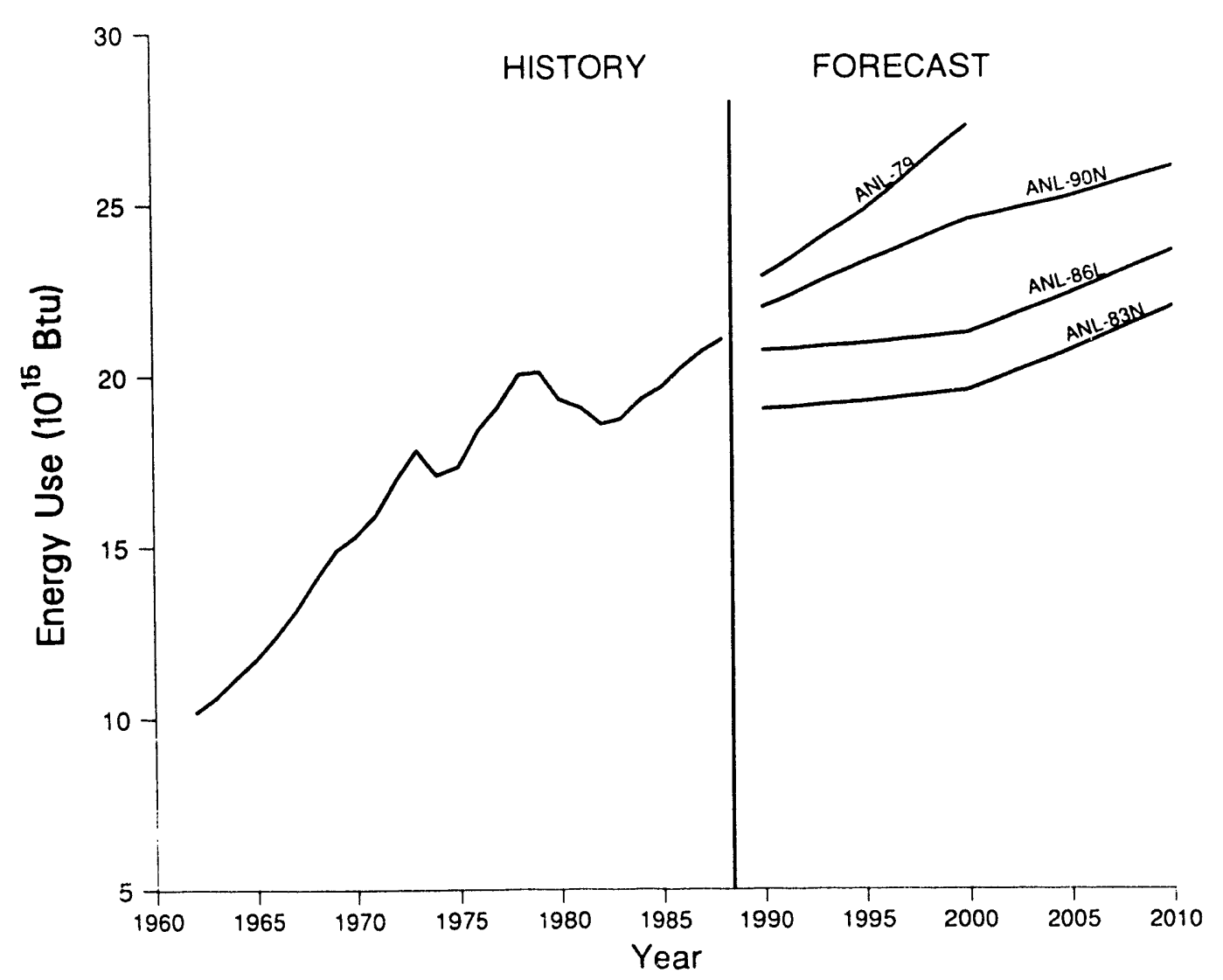

FIGURE 4.6 Projection Comparisons: Transportation Energy Use, 1960-2010

Historically, fuel cost per mile of travel has varied from a high of over $11 \notin$ in 1980 to less than $5 \propto$ in 1988 . This broad range illustrates the difficulty in forecasting the variable since it, in effect, compounds two uncertainties -- gasoline price and technological and market responses. Of the several forecasts, ANL- 86 has the lowest fuel cost since it combines very low gasoline prices with modest fuel economy improvements. ANL-90N is still relatively low by historical standards despite very modest fuel-economy assumptions (as compared with current forecasts, see Table 4.8). The ANL-83 projection shows the effect of assuming much higher gasoline prices with unchanged fuel-economy assumptiors. Although theoretically impossible since gasoline price is an independent variable in the model used to forecast light-duty fuel economy, the line illustrates the fuel cost per mile of travel if increased taxes were to raise gasoline prices to $\$ 2.00$ per gallon in 2000 and $\$ 3.00$ per gallon in 2010 and no additional fuel economy improvements were made.

Figure 4.9 relates the average fuel economy of the automotive fleet to gasoline price. Again, fuel price is much more variable than fuel economy. Further, while historical data suggest some relationship between the two, it $: s$ far from direct. A noteworthy difference between the latest forecast and its predecessors is in the slope of the fuel-economy curve. While earlier forecasts had assumed that the rate of improvernent would decline beyond 


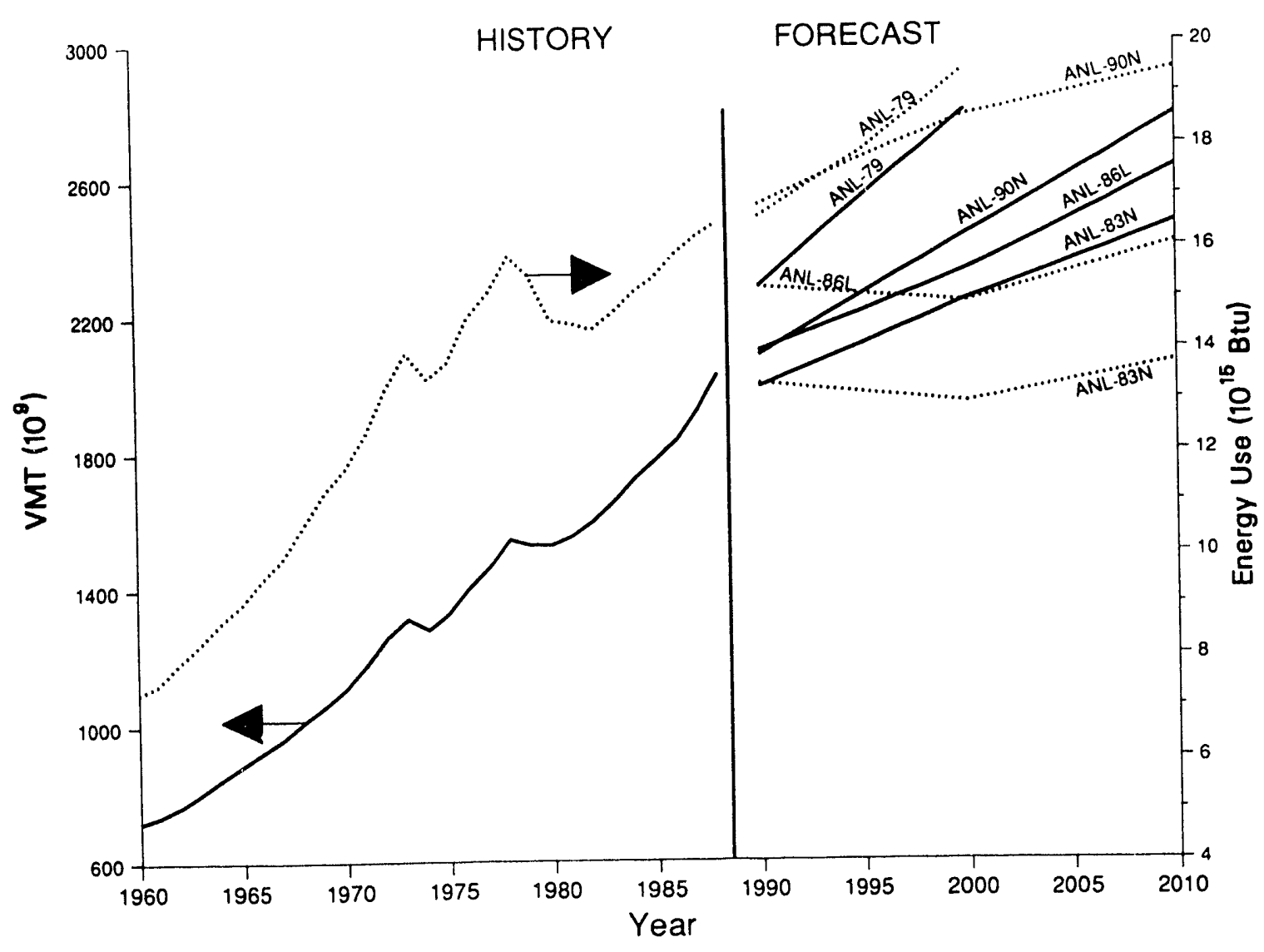

FIGURE 4.7 Projection Comparisons: Highway Travel and Fuel Use, 1960-2010

the year 2000, ANL-90N assumes some near-term technologies will be delayed, and additional fuel-efficient technologies will be introduced after the year 2000 . These technologies include advanced electronics, lighter weight, low-friction materials, and further improvements in aerodynamics and rolling resistance.

These technologies also include a number of unspecified light-duty fuel efficiency improvements predicted by the Greenhouse Gas Transportation and Emissions Model (GGTEM, a component of TEEMS). Because the efficiency assumptions of most forecasts (ANL as well as others) are based on specific technologies, there is a tendency to underestimate long-term efficiency gains. The technologies included in these and earlier ANL projections are themselves highly uncertain. The improvements that will come with technological maturity may exceed or fall short of our assumptions. Discoveries and other sciertific breakthroughs may make radically new technologies possible -- technologies that could dramatically alter lifestyles and energy demands. Because technology-specific projections are clouded by the impossibility of predicting these breakthroughs, projections tend to show declining gains in the distant future. Only macroeconomic or other trendbased models (e.g., GGTEM) can capture the kind of unspecified improvements represented by radically new technologies. Thus, the post-2000 slope of the ANL- $90 \mathrm{~N}$ fuel economy line is considerably higher than in earlier ANL projections. 
77

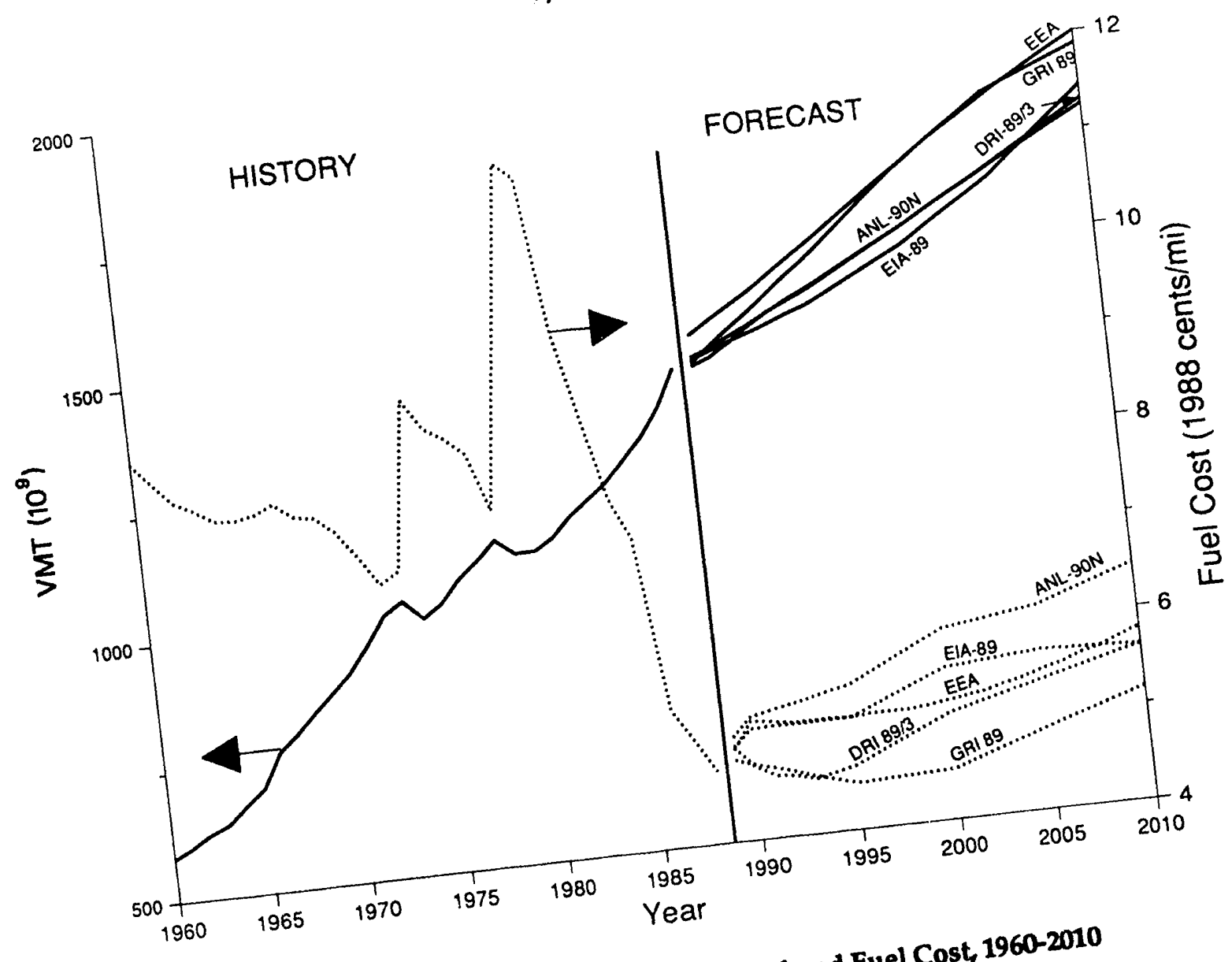

FIGURE 4.8 Projection Comparisons: Automotive Travel and Fuel Cost, 


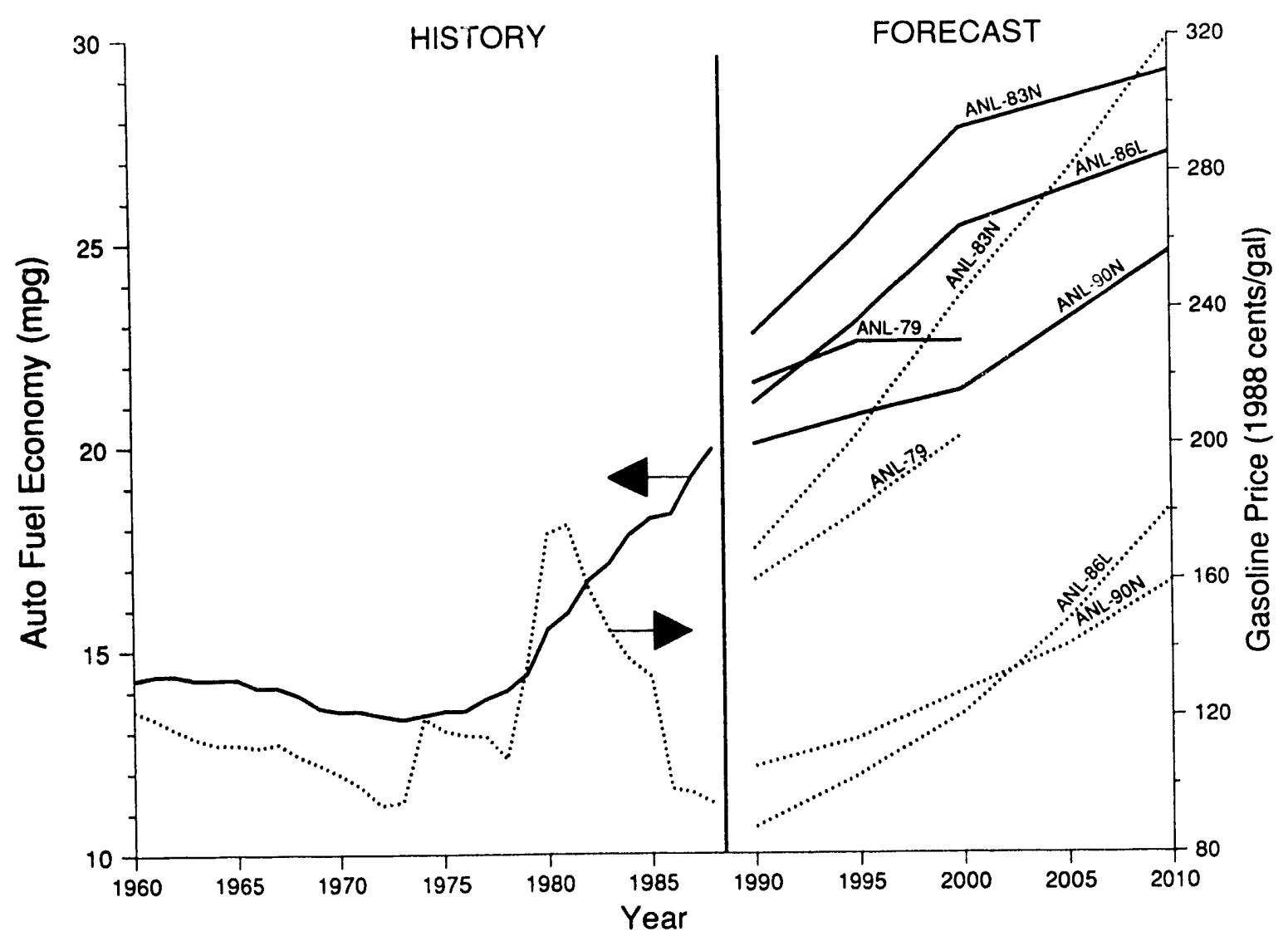

FIGURE 4.9 Projection Comparisons: Automotive Fuel Economy and Gasoline Price, 1960-2010 


\section{REFERENCES}

1. Vyas, A., M. Mintz, and Y. Gur, Modeling the Size and Composition of the U.S. Personal Vehicle Fleet, Proc. International Conference on Applied Simulation and Modeling, International Association of Science and Technology for Development, pp. 74-78 (Nov. 1989).

2. Millar, M., et al., Transportation Energy Outlook under Conditions of Persistently Low Petroleum Prices, Transportation Research Record 1155, Transportation Research Board, National Academy of Sciences (1988).

3. Vyas, A., and C. Saricks, Configuration for Forecasting Transportation-Source Emissions for the 1985 Test Runs, Argonne National Laboratory Report ANL/EES-TM321 (Oct. 1986).

4. Vyas, A., M. Millar, and P. Patterson, Transportation Energy Demand from 1980 to 2010: Structure and Results of the Transportation Energy and Emissions Modiling System, Proc. 14th IASTED International Conference and Exhibition on Applied Simulation and Modeling, International Association of Science and Technology for Development, pp. 362-268 (June 1986).

5. Saricks, C., The Transportation Energy and Emissions Modeling System (TEEMS): Selection Process, Structure, and Capabilities, Argonne National Laboratory Report ANL/EES-TM-295 (Nov. 1985).

6. Millar, M., and A. Vyas, Transportation Energy Demand from 1980 to 2010: The ANL85N2 Forecast, Argonne National Laboratory Report ANL/CNSV-TM-169 (Aug. 1985).

7. Millar, M., A. Vyas, and C. Saricks, Long-Term Outlook for Transportation Energy Demand, Transportation Research Record 1049, Transportation Research Board, National Academy of Sciences (1985).

8. Millar, M., et al., Baseline Projections of Transportation Energy Consumption by Mode: 1981 Update, Argonne National Laboratory Report ANL/CNSV-28 (April 1982).

9. Knorr, R., and M. Millar, Projections of Direct Energy Consumption by Mode: 19752000 Baseline, Argonne National Laboratory Report ANL/CNSV-4 (Aug. 1979).

10. National Energy Policy Plan Projections, U.S. Department of Energy, Office of Technology Policy, unpublished information (Jan. 1989).

11. The DRI Annual Model of the U.S. Economy: PC Version, Data Resources, Inc., Lexington, Mass. (1986). 
12. Projections of the Population of the United States by Age, Sex and Race: 1988 to 2080, U.S. Department of Commerce, Bureau of the Census, Current Population Reports Series P-25, No. 1018 (Jan. 1989).

13. Projections of the Number of Households and Families: 1986 to 2000, U.S. Department of Commerce, Bureau of the Census, Current Population Reports Series P-25, No. 986 (May 1986).

14. Fox, J., and C. Yuen, Argonne National Laboratory, unpublished information (1990).

15. Characterization of Future Flexible Fuel Vehicle Attributes, Energy and Environmental Analysis, Inc., Arlington, Va. (Oct. 1988).

16. Santini, D., Argonne National Laboratory, unpublished information (Nov. 1989).

17. Ollman, O.T., Marginal Weighting of Transportation Survey Data, Transportation Research Record 675, Transportation Research Board, National Academy of Sciences (1978).

18. 1977 Nationwide Personal Transportation Study, U.S. Department of Transportation, Federal Highway Administration, public use tape.

19. 1983 Nationwide Personal Transportation Study, U.S. Department of Transportation, Federal Highway Administration, public use tape.

20. Malliaris, A.C., H. Hsia, and H. Gould, Concise Description of Auto Fuel Economy and Perjormance in Recent Model Years, SAE Paper 760045, Society of Automotive Engineers, Warrendale, Penn. (1976).

21. Hudson, C., Argonne National Laboratory, unpublished information (1982).

22. Santini, D.J., and A.D. Vyas, Theoretical Basis and Parameter Estimates for the Minority Transportation Expenditure Allocation Model (MITRAM), Argonne National Laboratory Report ANL/ES-159 (1988).

23. Vyas, A.D., D.J. Santini, and S.K. Marik, Minority Transportation Expenditure Allocation Model (MITRAM): User Documentation For The Personal Computer Spreadsheet Version, Argonne National Laboratory Report ANL/EES-TM-368 (1989).

24. Greene, D.L., CAFE or Price?: An Analysis of the Effects of Federal Fuel Economy Regulations and Gasoline Price on New Car MPG 1978-89, The Energy Journal, 11(4):65-86 (Oct. 1990).

25. Patterson, P., U.S. Department of Energy, Office of Transportation Systems, personal communication (Oct. 1989). 
26. Westbrook, F., and P. Patterson, Changing Driving Patterns and their Effect on Fuel Economy, presented at 1989 Society of Automotive Engineers Government/Industry Meeting, Washington, D.C. (May 1989).

27. DiFiglio, C., K.G. Duleep, and D.L. Greene, Cost Effectiveness of Future Fuel Economy Improvements, The Energy Journal, 11(1):65-86 (Jan. 1990).

28. Williams, L.S., and P.S. Hu, Light-Duty Vehicle MPG and Market Shares Report: Model Year 1989, Oak Ridge National Laboratory Report ORNL-6626 (April 1990).

29. The Future National Highway Program, 1991 and Beyond, Working Paper No. 12, Highway Requirements for Freight Movement, U.S. Department of Transportation, Federal Highway Administration (Feb. 1988).

30. Automobile Fuel Consumption in Actual Traffic Conditions, Organization for Economic Cooperation and Development, Paris (1982).

31. Report to Congress on Intelligent Vehicle-Highway Systems, U.S. Department of Transportation, Office of the Secretary Report DOT-P-37-90-1 (March 1990).

32. RTECS: Consumption Patterns of Household Vehicles 1985, U.S. Department of Energy, Energy Information Administration Report DOE/EIA-0464(85) (April 1987).

33. Chandler, W.U., H.S. Geller, and M.R. Ledbetter, Energy Efficiency: A New Agenda, The American Council For an Energy-Efficient Economy, Washington, D.C. (July 1988).

34. Rosenfeld, A.H., and R.J. Morris, Reducing the Use of Oil and Gas Through Improved Energy Efficiency, Testimony to the President's Outer Continental Shelf Task Force, Eureka, Cal. (June 28, 1989).

35. 1983 Commercial Fleet Manager's Survey, University of Michigan, Institute for Social Research, Survey Research Center, magnetic tape.

36. Highway Statistics, U.S. Department of Transportation, Federal Highway Administration (various years).

37. Federal Motor Vehicle Fleet Report, U.S. General Services Administration, Office of Federal Supply and Services (various years).

38. Lagasse, A., International Taxicab Association, personal communication (Feb. 1989).

39. Automotive Fleet Fact Book, Bobit Publishing Co., Redondo Beach, Cal. (various years.)

40. Urban Consortium Task Force Alternative Vehiclular Fuel Survey, New York City Energy and Telecommunications Office (May 1988). 
41. Berg, M.R., M.J. Converse, and D.H. Hill, Electric Vehicles in Commercial SectorApplications, University of Michigan Institute for Social Research, for Detroit Edison Co. and the Electric Power Research Institute (July 1984).

42. National Transportation Statistics, U.S. Department of Transportation, Research and Special Projects Administration (various years).

43. Davis, S., et al., Transportation Energy Data Book: Edition 10, Oak Ridge National Laboratory Report ORNL-6565 (Sept. 1989).

44. Gately, D., Taking Off: The U.S. Demand for Air Travel and Jet Fuel, The Energy Journal, 9(4):63-91 (1988).

45. Evaluation of the Transportation Energy and Emissions Modelling System (TEEMS), Cambridge Systematics, Inc., Berkeley (1988).

46. Current Market Outlook, Boeing Commercial Airplane Group Report C22396, Seattle (Feb. 1990).

47. FAA Aviation Forecasts Fiscal Years 1990-2001, U.S. Department of Transportation, Federal Aviation Administration Report FAA-APO-90-1 (March 1990).

48. Sheehan, J.J., Flight Planning for the Future: Deregulation's Impact, 14th Annual FAA Aviation Forecast Conference Proc., Federal Aviation Administration Report FAAAPO89-2 (March 1989).

49. Smith, A.D., The Next Fifty Years in Jet Propulsion: European Perspective, Celebration of the Golden Anniversary of Jet Powered Flight, 1939-1989, Dayton, pp. 60-67 (Aug. 23, 1989).

50. Swihart, J.M., Aeronautical Developments for the 21st Century, The Boeing Company, Seattle (1987).

51. 1990-91 I. AA Aviation System Capacity, Federal Aviation Administration Report DOT/FAA/SC-90-1 (Sept. 1990).

52. Greene, D. L., Energy Efficiency Improvement Potential of Commercial Aircraft to 2010, Oak Ridge National Laboratory Report ORNL-6622 (June 1990).

53. Johnson, L.R., Maglev Vehicles and Superconductor Technology: Integration of High Speed Ground Transportation into the Air Travel System, Argonne Nationa! Laboratory Report ANL/CNSV-67 (April 1989).

54. Willigens, J.M., and H.G. Kraus, Specific Aspects of Maglev Links in the Different Types of Connections with Air Transportation, 11th International Conference on Magnetically Levitated Systems and Linear Drives, Yokahama, Japan (July 1989). 
55. Annual Energy Outlook, U.S. Department of Energy, Energy Information Administration Report DOE/EIA-0383(90) (Jan. 1990).

56. Energy Review, Data Resources, Inc./McGraw-Hill, Lexington, Mass. (Winter 1989-90).

57. Holtberg, P.D., et al., Baseline Projection Data Book, 1989 GRI Baseline Projection of U.S. Energy Supply and Demand to 2010, Gas Research Institute, Strategic Planning and Analysis Division, Washington, D.C. (1990).

58. Santini, D.J., et al., Argonne National Laboratory, unpublished information (April 1990).

59. Streets, D.G., et al., Methods for Modeling Future Emissions and Control Costs, National Acid Precipitation Assessment Program, Report SOS/T26, in Vol. 4 of Acidic Deposition: State of Science and Technology, Washington, D.C. (1990).

60. Chiang, Y.S., et al, A Short-Run Freight Demand Model: The Joint Choice of Mode and Shipment Size, Massachusetts Institute of Technology, Center for Transportation Studies Report 80-16, Cambridge, Mass. (Aug. 1980).

61. Harrington, I.F., and F.L. Mannering, A Methodc!ogy for the Evaluation of Freight Transportation Energy Contingency Strategies, Proc. of the 23rd Annual Meeting of the Transportation Research Forum, Northfield, N.J., pp. 668-676 (1982).

62. 1982 Truck Inventory and Use Survey, U.S. Department of Commerce, public use tape.

63. Barneft, J., Tech Trends in Trucking, Automotive News, Crain Communications, Detroit (Jan. 9, 1989).

64. Strawthorn, L.W., and V.A. Suski, Future Heavy Duty Trucking Engine Requirements, American Trucking Associations, Alexandria, Va. (March 1985).

65. Energy and Environmental Analysis, Inc., unp̧ublished information (Feb. 1989).

66. Larsen, R.P., A.R. Vyas, and A.P.S. Teotia, The Application of Ceramics to Heat Engines: An Economic Assessmeilt Based on a Worldwide Delphi Survey, SAE Paper 885167, Society of Automotive Engineers, Warrendale, Penn. (Sept. 1988).

67. Brands, M.C., et al., Vehicle Testing of Cummins Turbocompound Diesel Engine, SAE Paper 810073, Society of Automotive Engineers, Warrendale, Penn. (Feb. 1981).

68. Holtman, R.H., Testing of a Low Specific Fuel Consumption Turbocompound Engine, SAE Paper 870300, Society of Automotive Engineers, Warrendale, Penn. (Feb. 1987). 
69. 1977 Truck Inventory and Use Survey, U.S. Department of Commerce, Bureau of the Census, public use tape (1980).

70. 1987 Truck Inventory and Use Survey, U.S. Department of Commerce, Bureau of the Census, public use tape (1990).

71. Amdall, J.K., Initial Operating Results from Caterpillar 3600 Diesel Engine, American Society of Mechanical Engineers, Energy Sources Technology Conference and Exhibition ASME Paper 87-ICE-30, New York (Feb. 15-20, 1987).

72. Waterborne Commerce of the United States, U.S. Army Corps of Engineers, Water Resources Support Center, New Orleans (various years).

73. Baumgartner, P., and N. Mikulicic, The New Four-Stroke Diesel Engine Sulzer S20, Motortechnische Zeitschrift, 50(11): 502-508 (Nov. 1989).

74. Sekar, R.R., Argonne National Laboratory, unpublished information (April 1989).

75. Railroad Facts, Association of American Railroads, Information and Public Affairs Department, Washington, D.C. (various years).

76. Annual Energy Review 1989, U.S. Department of Energy, Energy Information Administration Report DOE/EIA-0384(89) (May 1990).

77. Carlsmith, R.S., et al., Energy Efficiency: How Far Can We Go? Oak Ridge National Laboratory Report ORNL/TM-11441 (Jan. 1990).

78. The Motor Vehicle Fuel Consumption Model 14th Periodical Report, Energy and Environmental Analysis, Inc., U.S. Department of Energy, Office of Policy, Planning and Analysis Report DOE/OR/21400-H12 (Dec. 1988).

79. Patterson, P.D., U.S. Department of Energy, Office of Transportation Technologies, personal communication (Oct. 1990).

80. Vyas, A.D., an C.L. Saricks, Transportation Energy and Emissions Modeling System (TEEMS): Configuration for Forecasting Transportation-Source Emissions for the 1985 Test Runs, Argonne National Laboratory Report ANL/EES-TM-321 (Oct. 1986).

81. Bohi, D.R., Analyzing Demand Behavior: A Study of Energy Elasticities, Resources for the Future, Inc., Johns Hopkins University Press, Baltimore (1981).

82. Wheaton, W.C., The Long-Run Structure of Transportation and Gasoline Demand, The Bell Journal of Economics, 13(2):439-454 (Aug. 1982).

83. Cohen, B.N., U.S. Deptartment of Energy, Energy Information Administration, unpublished information (Nov. 1989). 


\section{APPENDIX A:}

\section{ESTIMATION OF BASE-YEAR FREIGHT MOVEMENTS}

Several clata sources were used to estimate base year (1985) fieight movements. The 1985 One Percent Rail Waybill Sample ${ }^{1}$ and the Association of American Railroads' Railroad Facts ${ }^{2}$ were used to estimate rail ton-miles of travel; Waterborne Commerce of the United States, ${ }^{3}$ published by the U.S. Army Corps of Engineers, was used to estimate marine ton-miles of travel; and published data from the Association of Oil Pipelines and U.S. Department of Transportation ${ }^{4}$ were used to estimate pipeline and air cargo movements.

Truck ton-miles of travel (TMT) and vehicle-miles of trarrol (VMT) were estimated using a sequential procedure in which data from the 1977 Commodity Transportation Survey were supplemented by average load factors by commodity sector. The load factors were initially computed using data from the 1982 Truck Inventory and Use Survey 5 (TIUS) and then adjusted to reflect empty haul. Historical growth rates in sectoral TMT were estimated using growth indexes of sectoral economic output from Data Resources Inc.'s macroeconomic model.6-8 The 1982 TIUS load factors were applied to these TMT and the resulting VMT were compared to the VMT totals published by the Federal Highway Administration. ${ }^{9}$

Table A.1 shows 1982 truck TMT, VMT, and VMT shares by truck size for major commodity sectors as estimated from the 1982 TIUS. Truck load factors are also shown in the table. These load factors are substantially higher than those used in earlier ANL projections. ${ }^{10}$ The 1982 TIUS asked a question regarding percent of the time a product was carried. These data and the reported average load were used to compute average load factors in Table A.1. The values are not adjusted for empty haul. Table A.2 shows 1985 truck TMT and VMT as the residual TMT after TMT by other modes, as shown in Table A.3, were subtracted from the sectoral TMTs computed using growth since 1977. Truck load factors for some commodities were adjusted to reflect empty back haul.

The ANL freight sector model uses sectoral energy intensities for all modes except trucks. Tiuck energy consumption is projected using fuel economy in terms of miles per gallon and average load factors (shown in Table A.2). Rail and marine energy intensities ere computed using the total fuel sales by mode as published in the Petroleum Marketing Monthly. ${ }^{11}$ The differences between energy intensities of various sectors were held constant from 1977. An aggregate air cargo intensity was computed using data from National Transportation Statistics, ${ }^{4}$ while pipeline energy intensities were estimated using data from pipeline associations. Table A.4 lists the estimated energy intensities by mode and commodity sector. 


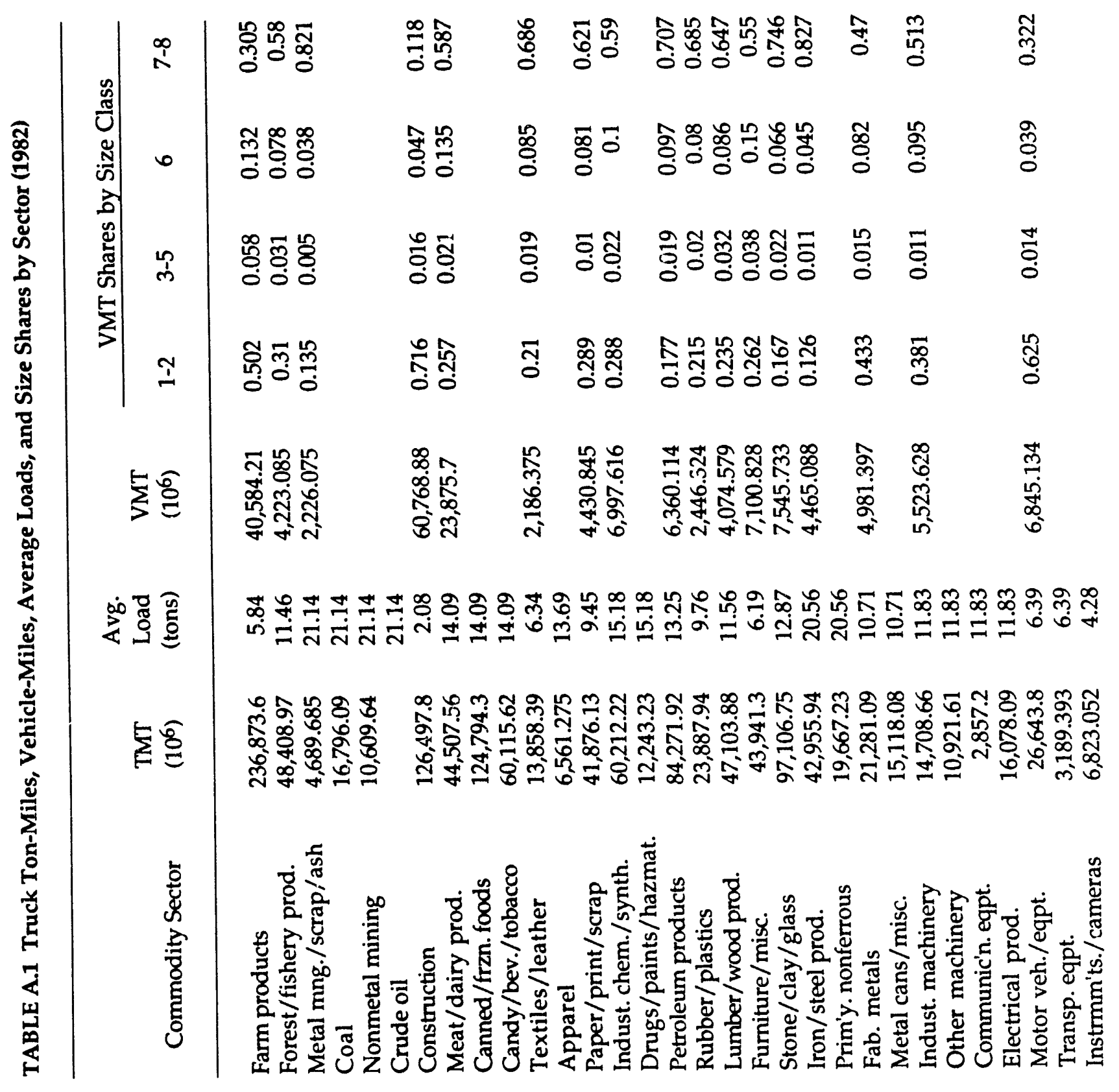




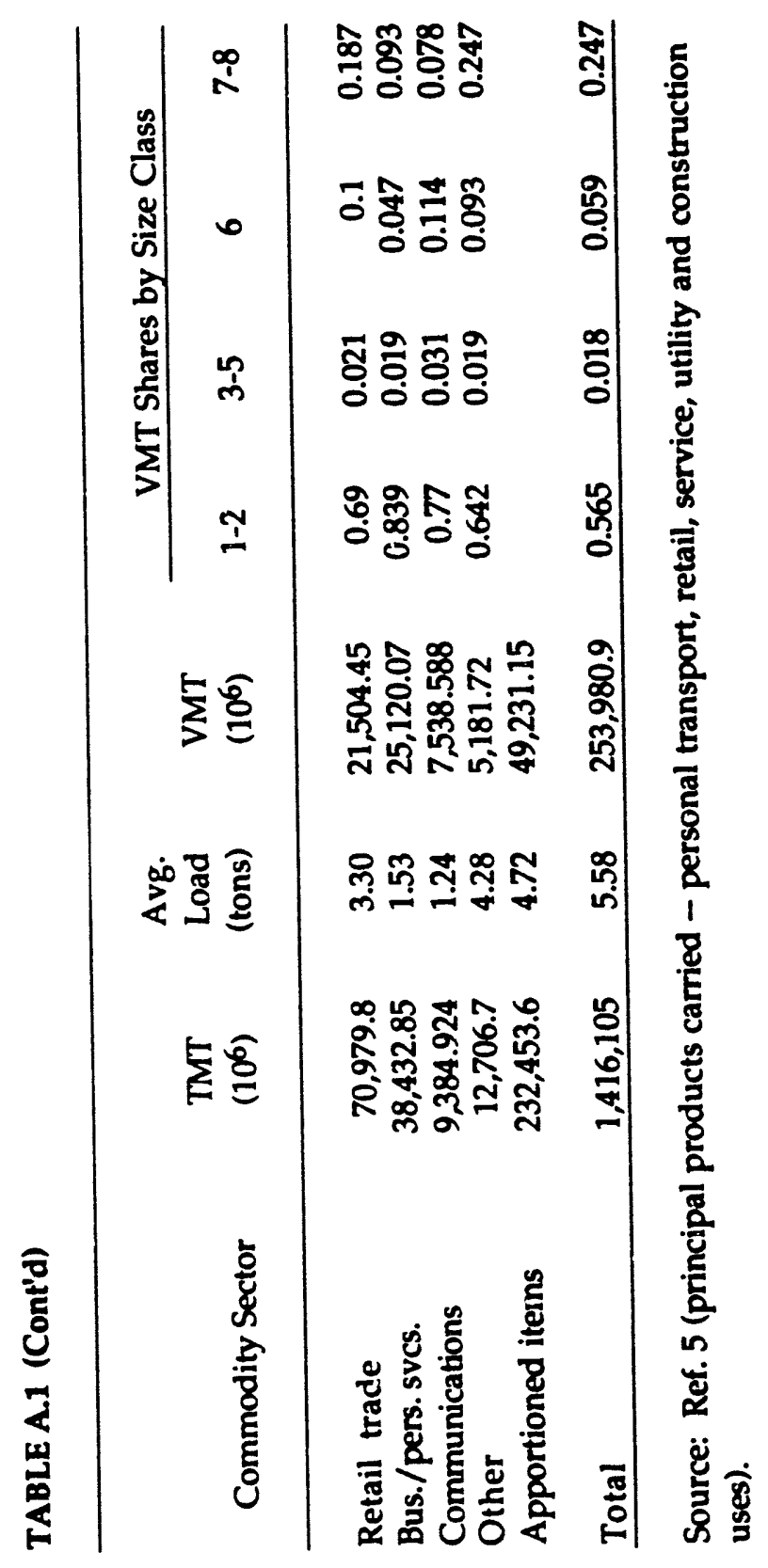




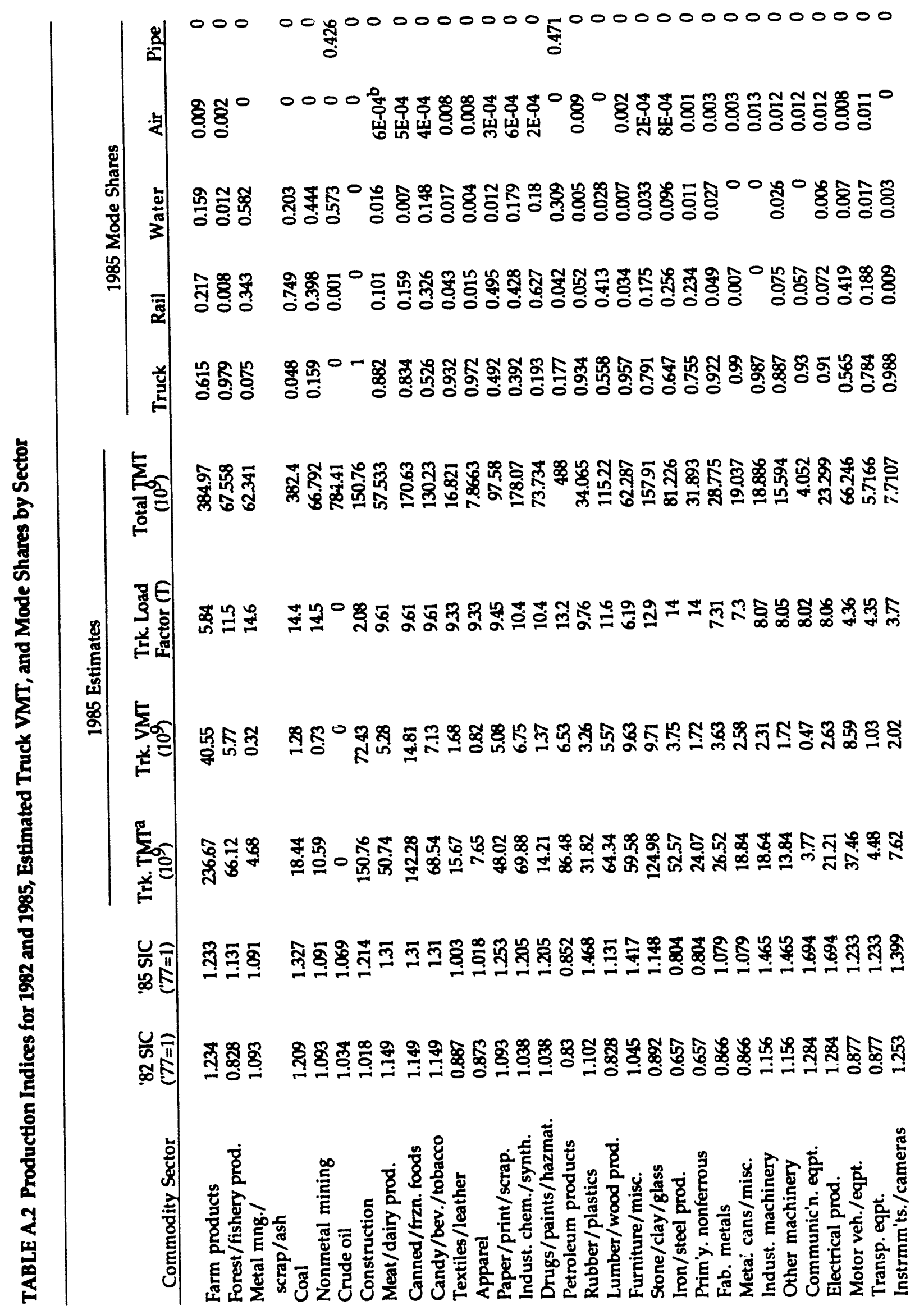




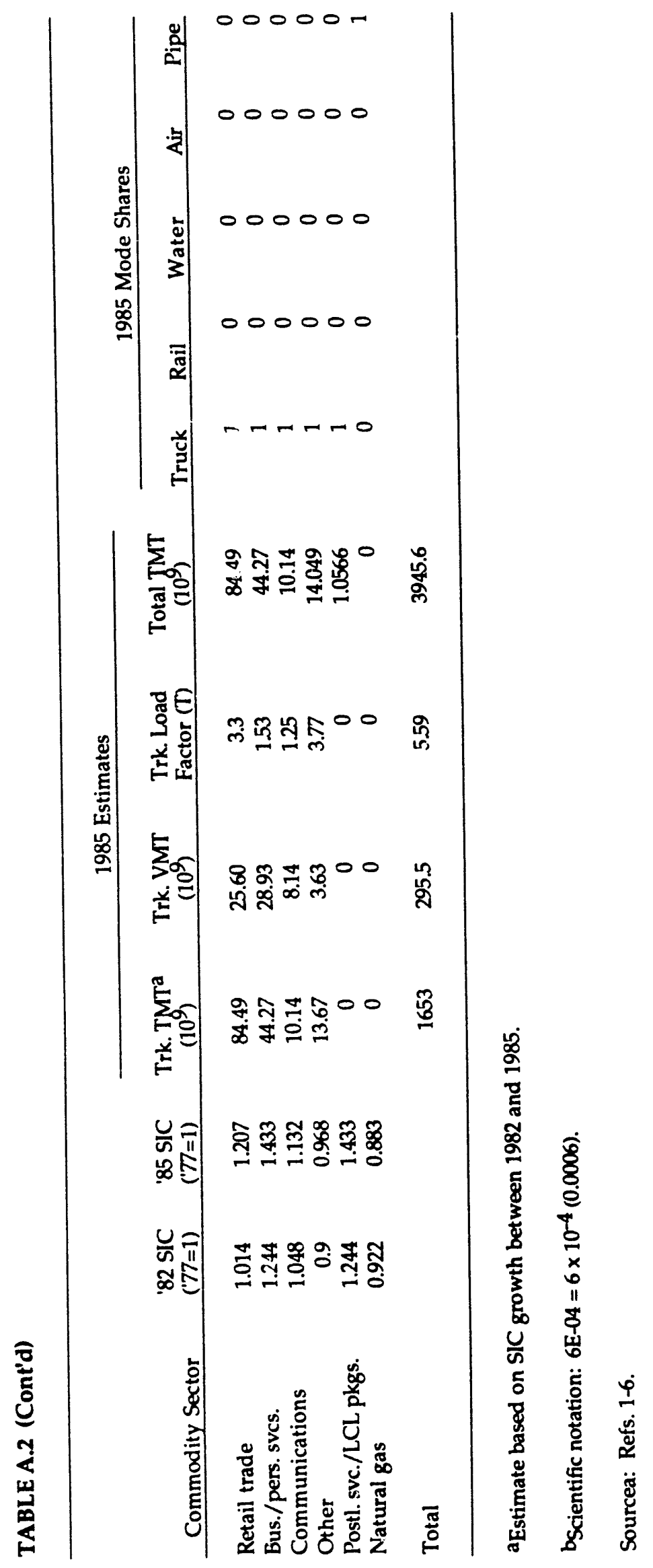




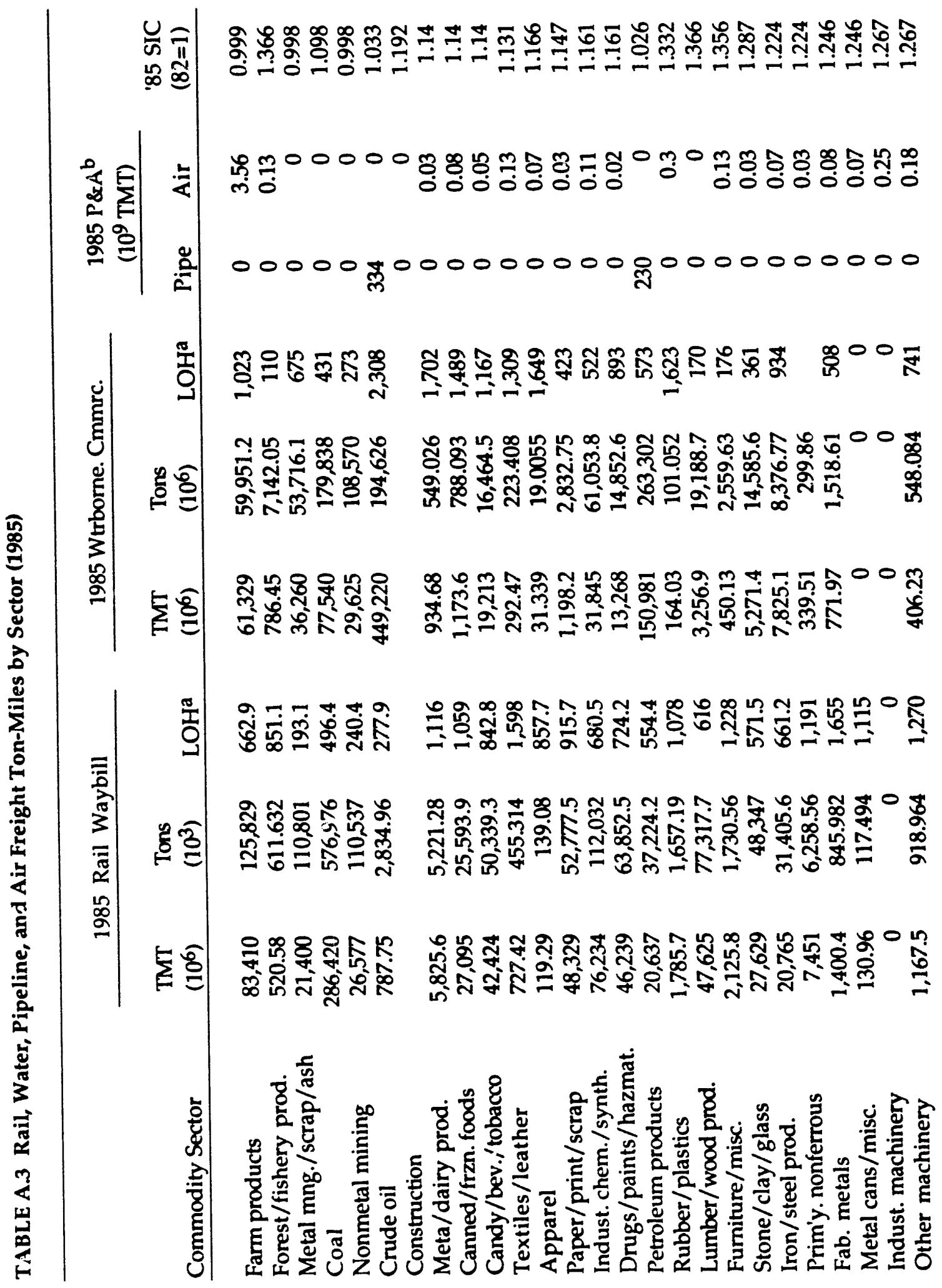




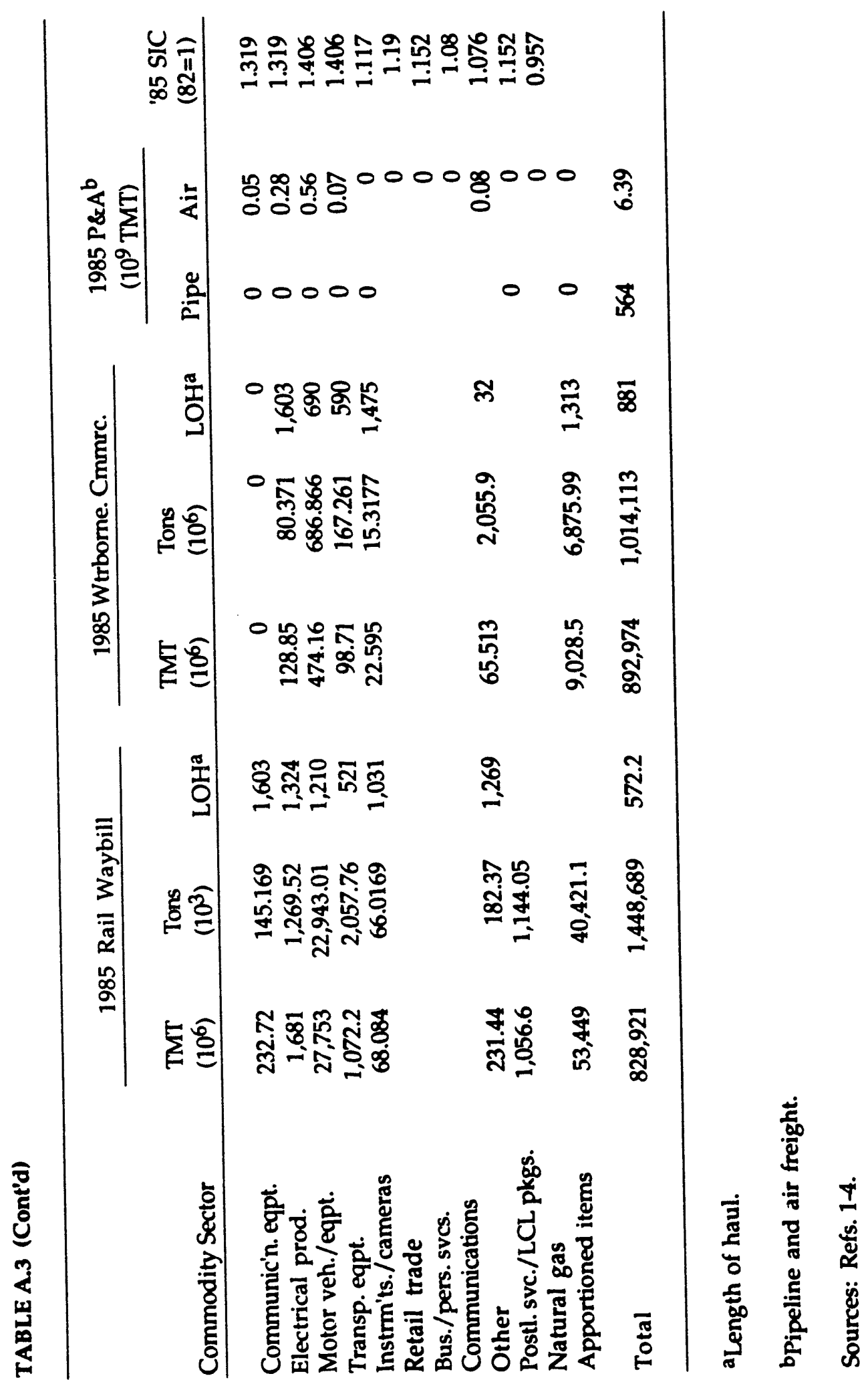


TABLE A.4 Freight Sector Energy Intensities for Nonhighway Modes

\begin{tabular}{|c|c|c|c|c|}
\hline \multirow[b]{2}{*}{ Commodity Sector } & \multicolumn{4}{|c|}{ Energy Intensity (Btu/TMT) } \\
\hline & Rail & Marine & Air & Pipeline \\
\hline Farm products & 465 & 422 & 9850 & $\mathrm{NA}^{\mathrm{a}}$ \\
\hline Forestry \& Fishery & 477 & 324 & 9850 & NA \\
\hline Metal mining & 457 & 448 & NA & NA \\
\hline Coal mining & 428 & 422 & NA & NA \\
\hline Nonmetal mining & 462 & 448 & NA & NA \\
\hline Crude oil & 582 & 358 & NA & 250 \\
\hline Construction & 459 & 324 & NA & NA \\
\hline Meat \& dairy & 613 & 291 & 9850 & NA \\
\hline Canned, frozen \& other & 613 & 291 & 9850 & NA \\
\hline Candy, cookies, bev. & 613 & 291 & 9850 & NA \\
\hline Textiles \& leather & 883 & 403 & 9850 & NA \\
\hline Apparel \& related & 883 & 403 & 9850 & NA \\
\hline Paper products & 599 & 332 & 9850 & NA \\
\hline Ind. chem. \& syn. matrls. & 472 & 318 & 9850 & NA \\
\hline Drugs, paints, othr. chem. & 472 & 318 & 9850 & NA \\
\hline Petroleum products & 460 & 349 & 9850 & 300 \\
\hline Rubber \& misc. plastic & 459 & 324 & 9850 & NA \\
\hline Lumber \& wood & 542 & 324 & 9850 & NA \\
\hline Furniture \& fixtures & 542 & 324 & 9850 & NA \\
\hline Stone, clay, \& glass & 459 & 427 & 9850 & NA \\
\hline Iron \& steel prod. & 467 & 242 & 9850 & NA \\
\hline Prim. nonferrous metl. & 467 & 242 & 9850 & NA \\
\hline Fab. metal prod. & 666 & 278 & 9850 & NA \\
\hline Metal cans \& misc. & 666 & 278 & 9850 & NA \\
\hline Industrial machinery & 866 & 403 & 9850 & NA \\
\hline Other machinery & 866 & 403 & 9850 & NA \\
\hline Communication eqp. & 1114 & 403 & 9850 & NA \\
\hline Electrical products & 1114 & 403 & 9850 & NA \\
\hline Motor veh. \& eqp. & 856 & 283 & 9850 & NA \\
\hline Transportation eqp. & 856 & 283 & 9850 & NA \\
\hline Instruments, cameras, etc. & 459 & 403 & 9850 & NA \\
\hline Whlsale \& retail trade & 459 & 403 & 9850 & NA \\
\hline Bus. \& pers. services & 459 & 403 & 9850 & NA \\
\hline Communications & 459 & 403 & 9850 & $\mathrm{NA}$ \\
\hline Other & 459 & 403 & 9850 & NA \\
\hline Postal services & 485 & 324 & 9850 & NA \\
\hline Natural gas & NA & NA & NA & 2524 \\
\hline
\end{tabular}

aNA $=$ not applicable.

Sources: Refs $1-4,11$. 


\section{REFERENCES FOR APPENDIX A}

1. Onz Percent Waybill Sample, Federal Railroad Administration, Washington, D.C. (1987).

2. Railroad Facts, Association of American Railroads, Washington, D.C. (1987).

3. Waterborne Commerce of the United States, U.S. Army Corps of Engineers, Water Resources Support Center, New Orleans, La. (1987).

4. National Transportation Statistics, Research and Special Programs Administration, U.S. Department of Transportation, Washington, D.C. (1988).

5. The 1982 Truck Inventory and Use Survey: Public Use Tape, Bureau of the Census, U.S. Department of Commerce, Washington, D.C. (1984).

6. The DRI Annual Model of the U.S. Economy: PC Version, Data Resources Inc., Lexington, Mass. (1986).

7. Pieper, P.J., et al, Review of the DRI Long-Term Macroeconomic Projections and Their Extension to the Year 2030, Argonne National Laboratory Report ANL/EESTM-358 (April 1985, Revised Nov. 1988).

8. Boyd, G., et al., Effect of the Changing Composition of U.S. Manufacturing Production on Energy Demand, Argonne National Laboratory Report ANL/EESTM-298 (Feb. 1986).

9. Highway Statistics 1985, Federal Highway Adminisiration, U.S. Department of Transportation, Washington, D.C. (1986).

10. Vyas, A.D., and C.L. Saricks, Transportation Energy and Emissions Modeling System (TEEMS): Configuration for Forecasting Transportation-Source Emissions for the 1985 Test Runs, Argonne National Laboratory Report ANL/EES-TM-321, (Oct. 1986).

11. Petroleum Marketing Monthly, Energy Information Administration, U.S. Department of Energy, Washington, D.C. (1986). 


\section{APPENDIX B:}

\section{ESTIMATION OF 1985 PERSONAL TRAVEL}

The personal travel component of Argonne National Laboratory's Transportation Energy and Emissions Modeling System (TEEMS) is driven by demographic data. The component, also known as the Disaggregate Personal Transportation Activity Model (DPTAM), has three distinct models: the Iterative Proportional Fitting (IPF) model, the Vehicle Ownership Projection (VOP) model, and the Disaggregate Vehicle Stock Allocation Model (DVSAM). The personal travel projections process is dependent on a base-year matrix of households that is modified by the first two models. The third model develops a distribution of household vehicle holdings that when used with on-road fuel economies of various household vehicles provides estimates of personal travel energy consumption. This appendix describes the process employed in developing a 1985 households matrix and various data sources used for verification of the results produced by the three nodels.

\section{B.1 DEVELOPMENT OF A BASE-YEAR HOUSEHOLDS MATRIX}

A 1983 households matrix was first developed using data from the 1983 Nationwide Personal Transportation Study (NPTS). ${ }^{1}$. Household distributions by each of the six attributes used by the modeling system were developed for the year 1985 . The attributes used are (1) location, (2) income, (3) age oi householder, (4) household size, (5) number of drivers, and (6) number of vehicles. Each attribute has three or four classes, for a total of 3,072 cells, as described in Sec. 2.1 of this report. Several of these cells, such as two and three or more drivers for single-person households, are improbable and thus remain empty.

In developing the 1985 household distributions, the 1983 distribution for the location attribute was kept unchanged while new distributions by age of the householder and household size were developed. ${ }^{2}$ The 1983 distribution of households by income was updated to 1985 using percent distribution of households by income cldss (in 1986 dollars) from Ref. 2. We used the ratio between mean and median income to compute a 1985 household distribution by income class.

The share of driving-age population licensed to drive is increasing with time. The 1983 NPTS reported $83.6 \%$ of persons over age 15 to be licensed to drive. The share increased to $85.6 \%$ by 1986.2 We estimated the 1985 share of drivers by computing annual rates of change for each age group. The resulting shares are shown in Table B.1.

The 1983 NPTS data showed an average of 3.34 drivers for households with 3 or more drivers. We estimated a 1985 average of 3.39 drivers for households in that group and computed a distribution of households by number of drivers. 
The Federal Highway Adminisiration's published data on vehicle registrations were used to estimate a distribution by vehicle ownership. ${ }^{3}$ The 1983 NPTS provided a distribution in which $13.6 \%$ of the households did not own any vehicles, $34.6 \%$ had one vehicle, $34.5 \%$ had two vehicles, and $17.3 \%$ had three or more vehicles. Some 126.444 million automobiles and 31.214 million light trucks (two axles, four tires) were registered in 1983. Using data from Sec. 2.2 of this report and from the 1982 Truck Inventory and Use Survey, 4 we estimated $93.1 \%$ of automobiles and $64.7 \%$ of light trucks to be household owned. A total of 131.864 million automobiles and 32.866 million light trucks were registered in 1985, from which we estimated 144.029
TABLE B.1 Share of Licensed Drivers by Age Group

\begin{tabular}{llll}
\hline & \multicolumn{3}{c}{ Percent Licensed } \\
\cline { 2 - 4 } Age & & & \\
Group & $1983^{\mathrm{a}}$ & 1985 & $1986^{\mathrm{b}}$ \\
\hline & & & \\
\hline & & & \\
$25-34$ & 78.4 & 81.2 & 82.6 \\
$35-44$ & 91.4 & 92.7 & 93.3 \\
$45-54$ & 88.8 & 92.3 & 92.7 \\
$55-64$ & 86.1 & 80.4 & 91.2 \\
$\geq 65$ & 62.3 & 63.8 & 86.9 \\
& & & \\
\hline
\end{tabular}

a Source: Ref 1.

b Source: Ref 2.

million household vehicles. We used this vehicle count to arrive at a 1985 distritribution of households by vehicle ownership. The computed distribution of households by number of vehicles is shown in Table B.2 as "Estimated 1985."

The above-estimated household distributions by six attributes were used to develop a first-cut base-year households matrix through the application of IPF. The resulting distributions of households are shown in Table B.2 as "1985 after IPF."

\section{B.2 APPLICATION OF THE VEHICLE OWNERSHIP MODEL}

The Vehicle Ownership Projection Model was applied next. The model uses gasoline price and per-capita disposable income. We used the retail unleaded gasoline price $^{5}$ and per-capita disposable income ${ }^{2}$ in 1982 dollars to arrive at values in 1983 dollars as required by the model. The resulting vehicle ownership is distributed such that the households distribution among other attributes does not change. The procedure used to ensure that the distribution of households among the first five attributes would remain unchanged is described below.

Let $B$ be the base matrix of $n$ elements containing fractions of households such that it represents an average vehicle ownership $V_{b}$ and $X$ be the final matrix that represents the new vehicle ownership $V_{x}$. The new matrix $X$ should meet the following conditions:

$$
\begin{array}{ll}
\sum x_{i}=1 & \text { for } i=1 \text { through } n \\
\sum x_{i}^{*} v_{i}=V_{x} & \text { for } i=1 \text { through } n
\end{array}
$$




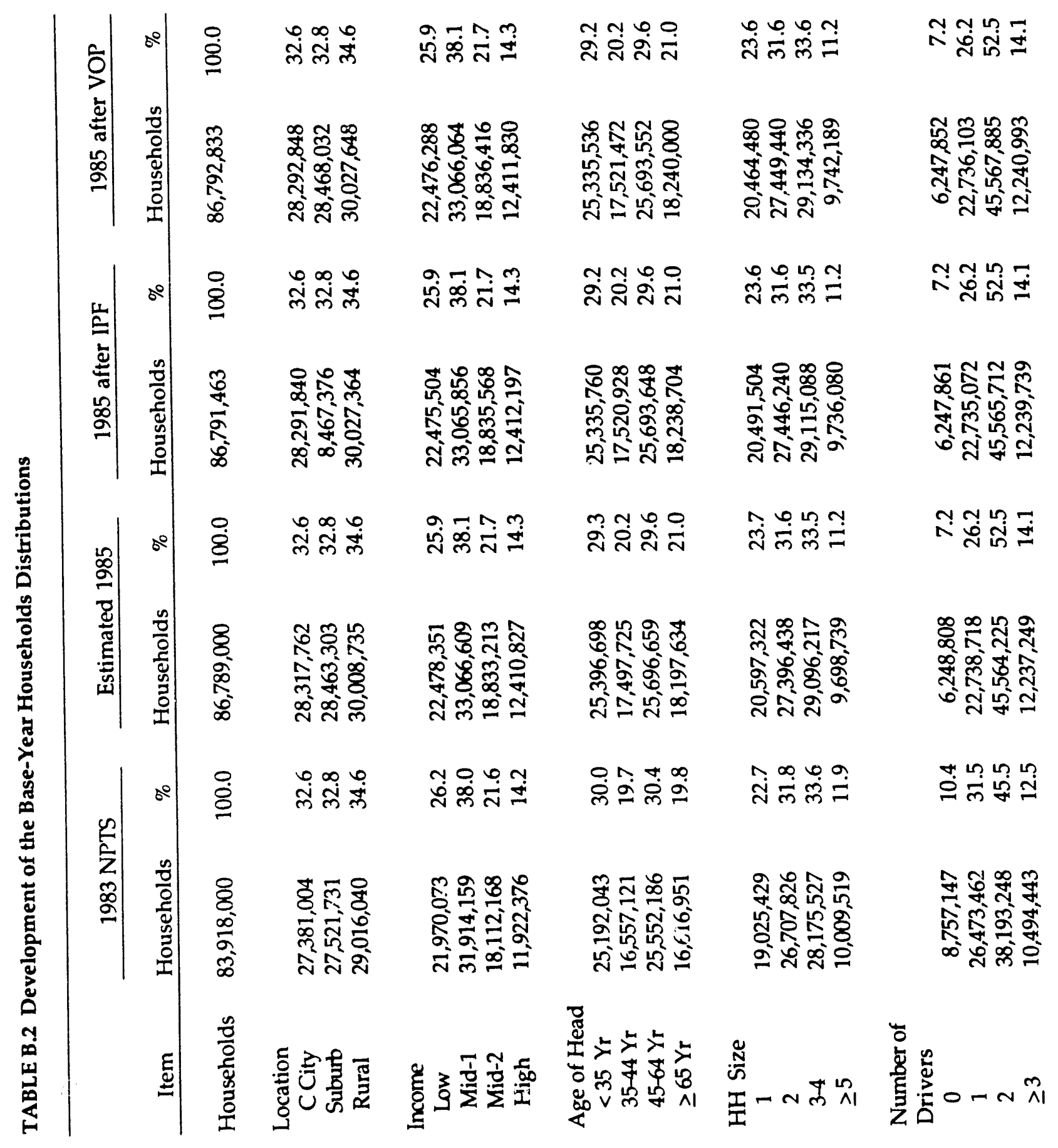




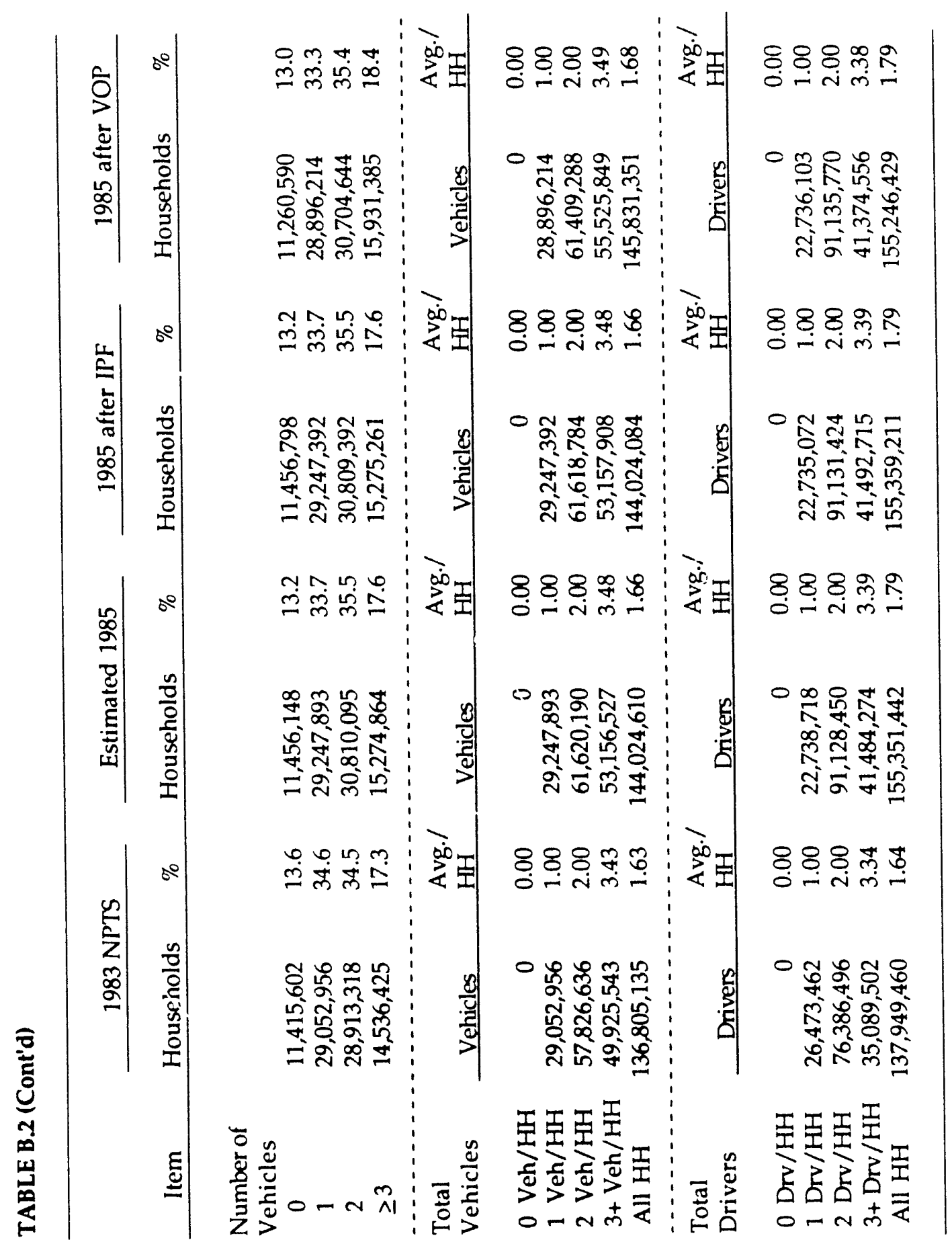


and $\quad x_{i}>=0$

Since the new matrix $X$ should be as close to the base matrix $B$ as possible, we define $\mathrm{Z}$ as the difference as follows:

$$
Z=\Sigma x_{i} \quad *\left[\ln \left(x_{i} / b_{i}\right)-1\right]
$$

The difference measure $Z$ is to be minimized, subject to Eqs. 1-3, to ensure that $X$ replicates $B$ as much as possible. The problem can be solved using Lagrange multipliers as follows:

$$
1=Z+\alpha^{*}\left(\Sigma x_{i}-1\right)+\beta *\left[\left(\Sigma x_{i}^{*} v_{i}\right)-V_{x}\right]
$$
solution:

When partial derivatives of Eq. 5 are set to zero, we achieve a unique minimum

$$
\partial \lambda / \partial x_{i}=\ln \left(x_{i} / b_{i}\right)+\alpha+\beta * v_{i}=0
$$

which gives,

$$
\begin{aligned}
& \ln \left(x_{i} / b_{i}\right)=-\alpha-\beta * v_{i} \\
& x_{i}=b_{i} * \exp \left(-\beta * v_{i}\right) * \exp (-\alpha)
\end{aligned}
$$

An iterative algorithm is employed to solve this problem.

The Vehicle Ownership Projection (VOP) model produced an increase in the average vehicle ownership from 1.66 to 1.68 and raised the share of multi-vehicle households, as shown in Table B.2 as "1985 after VOP." 


\section{REFERENCES FOR APPENDIX B}

1. 1983-84 Nationwiae Personal Transportation Study: Public Use Tape and User's Guide for the Public Use Tapes, Federal Highway Administration, U.S. Department of Transportation, Washington, D.C. (Nov. 1985)

2. Statistical Abstract of the United States 1988, 108th Edition, Bureau of the Census, U.S. Department of Commerce, Washington, D.C. (1988).

3. Highway Statistics: Summary to 1985, Federal Highway Administration, U.S. Department of Transportation, Washington, D.C. (1987).

4. Census of Transportation: 1982 Truck Inventory and Use Survey, Bureau of the Census, U.S. Department of Commerce, public use tape, 'Vashington, D.C. (1984).

5. Annual Energy Review 1987, Energy Information Administration Report DOE/EIA0384(87), U.S. Department of Energy, Washington, D.C. (May 1988). 


\section{DISTRIBUTION FOR ANL/ESD-9}

Internal

$\begin{array}{ll}\text { ANL Contract Copy } & \text { K.S. Macal (6) } \\ \text { ANL Patent Department } & \text { M.M. Mintz (500) }\end{array}$

ANL Technical Publications Services (3)

\section{External}

U.S. Department of Energy Office of Scientific and Technical Information (12) Manager, U.S. Department of Energy Chicago Operations Office

ANL Libraries (1) 

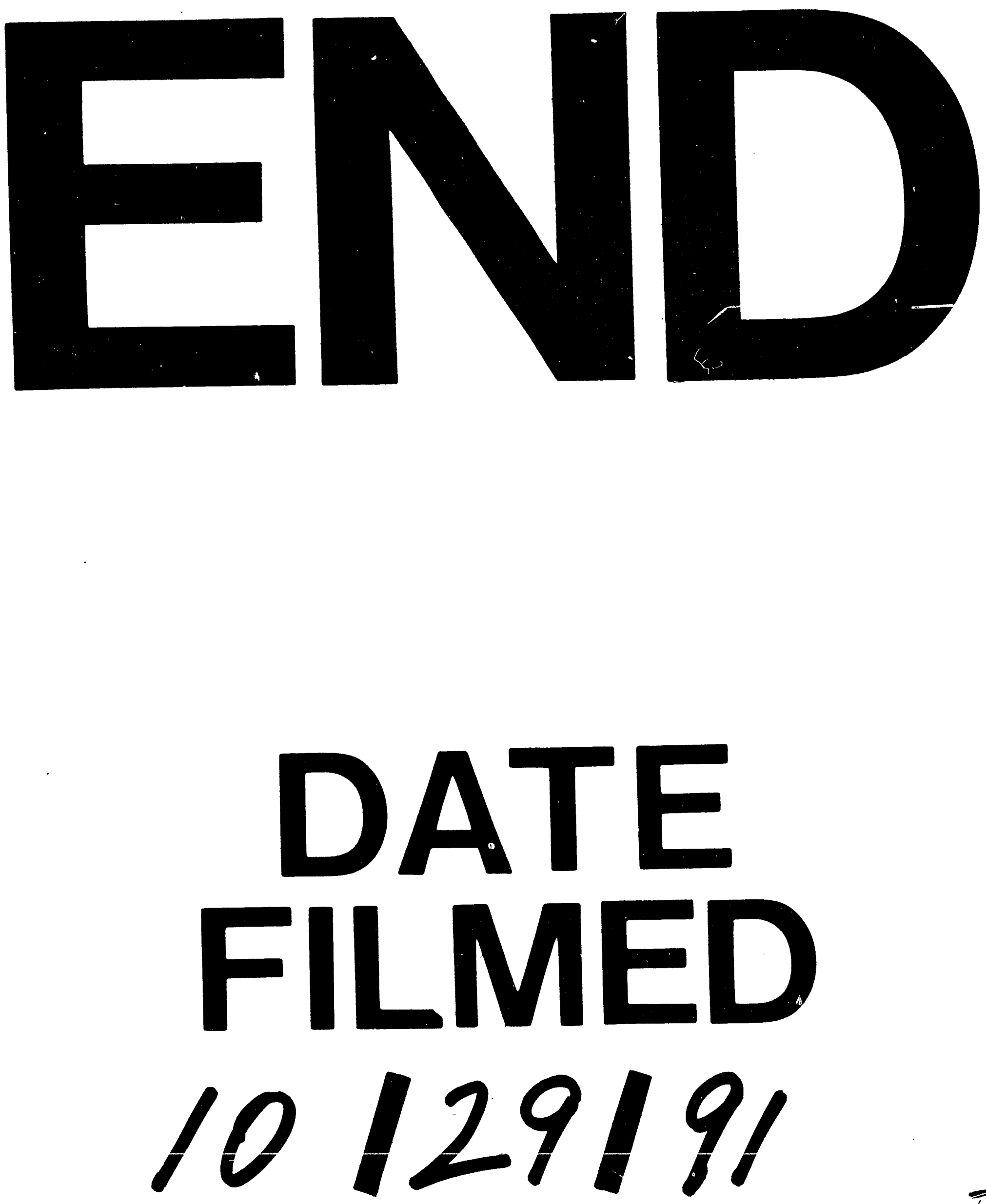

II 
